\title{
Multinationals and the Canadian Innovation Process
}

\author{
by \\ John Baldwin * \\ and \\ Petr Hanel ** \\ No. 151 \\ 11F0019MPE No. 151 \\ ISSN: 1200-5223 \\ ISBN: 0-660-18189-4 \\ * Statistics Canada \\ Micro-Economic Analysis Division \\ 24-B R.H. Coats Building \\ Ottawa, K1A 0T6 \\ (613) 951-8588 \\ Facsimile Number: (613) 951-5403 \\ Email: baldjoh@statcan.ca \\ ** Département d'Économique \\ Université de Sherbrooke \\ (819) 821-8000 ext. 2278 \\ Email:phanel@courrier.usherb.ca
}

June 2000

The authors' names are listed in alphabetical order.

This paper represents the views of the authors and does not necessarily reflect the opinions of Statistics Canada. 


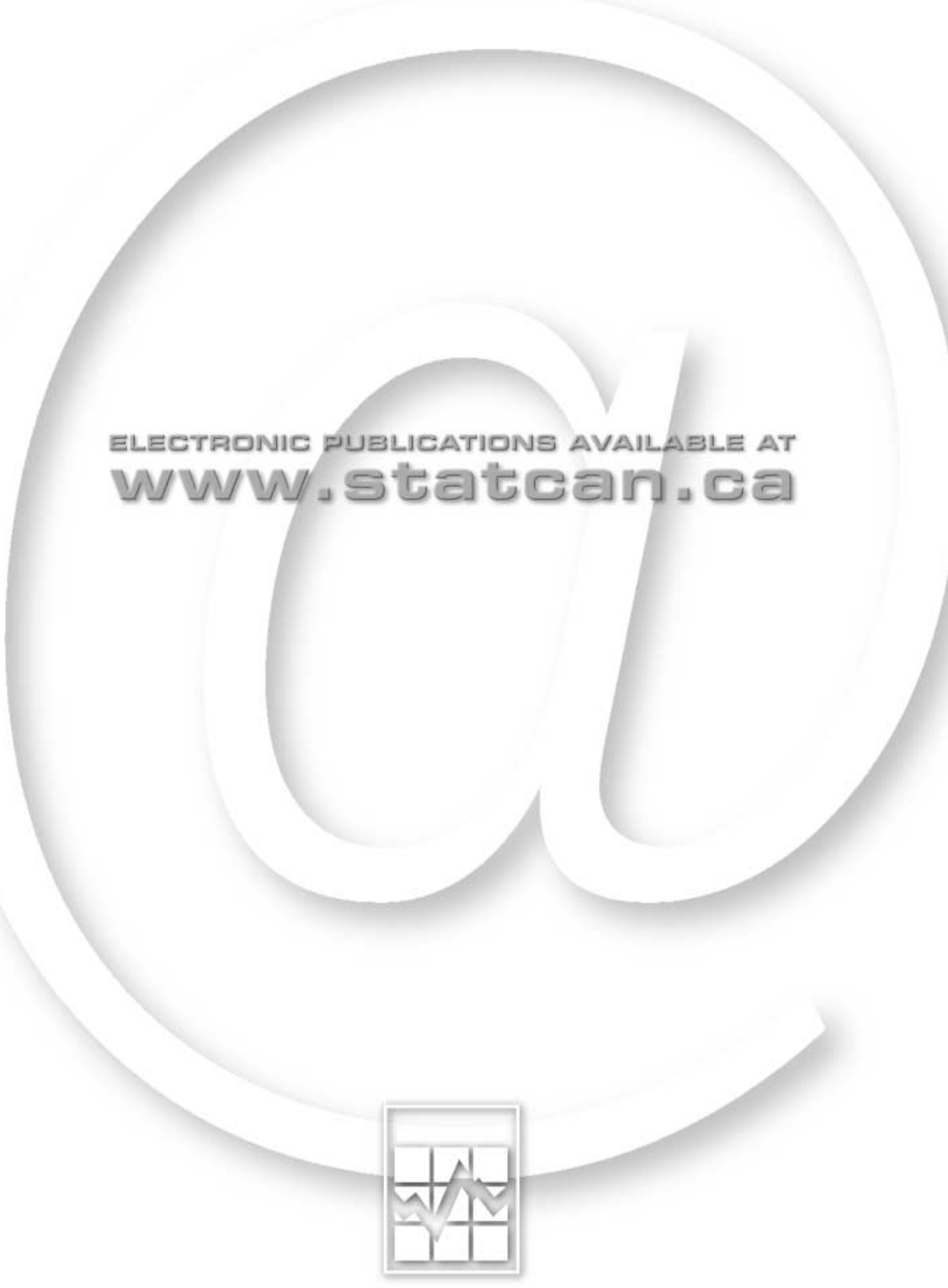




\section{Table of Contents}

ABSTRACT

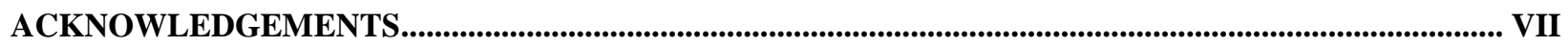

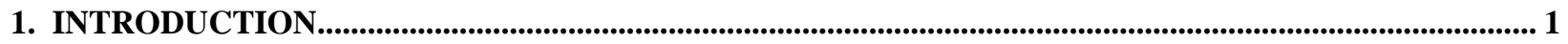

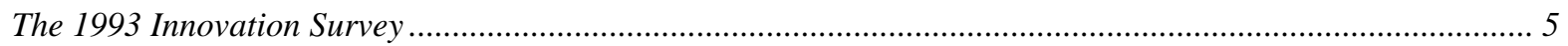

Characteristics of Canadian and Foreign-owned Firms: Size and Industry Differences................................... 5

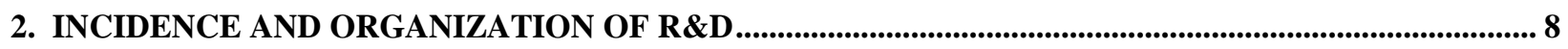

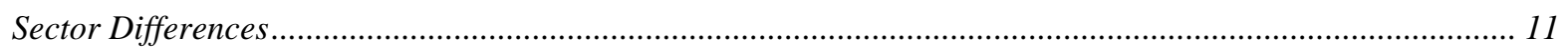

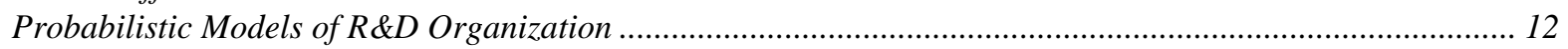

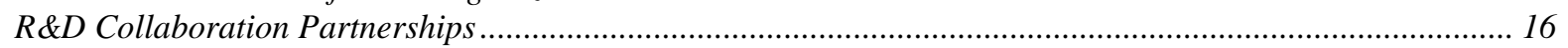

3. SOURCES OF NEW IDEAS AND INSPIRATION FOR INNOVATION ............................................... 19

How Important a Source of Innovative Ideas Are Foreign Parents and Sister Companies of Foreign-owned

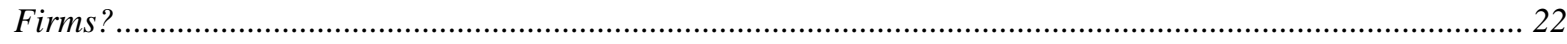

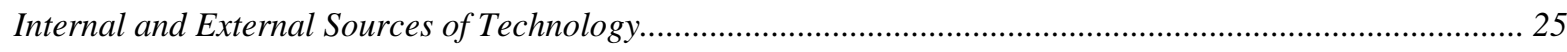

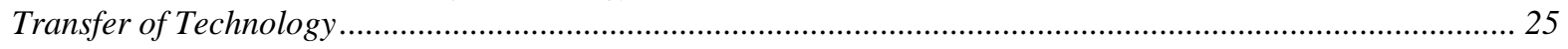

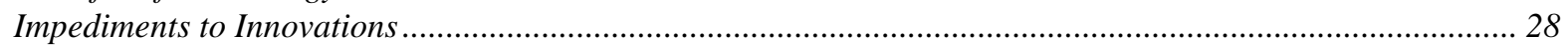

4. DO CANADIAN-OWNED FIRMS INNOVATE MORE OR LESS THAN FOREIGN AFFILIATES? . 31

Do Foreign-owned Firms Introduce Process Innovations More Often Than the Canadian-owned Firms? ...... 31

Originality of Innovations......................................................................................................................... 32

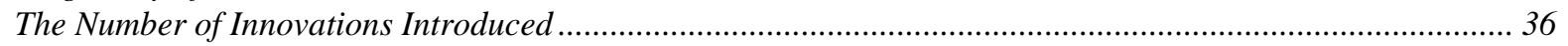

5. USE OF INTELLECTUAL PROPERTY RIGHTS................................................................................................... 36

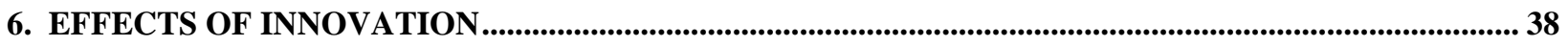

Do Foreign Affiliates Export More or Less Than Canadian-owned Firms? ................................................... 39

The Impact of Innovation on Employment and Skill Requirements ............................................................. 41

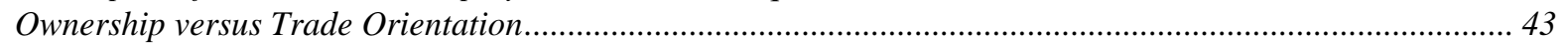

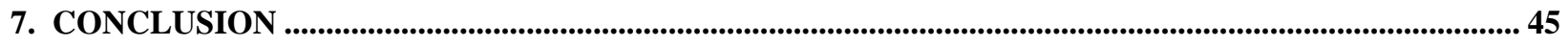

APPENDIX A

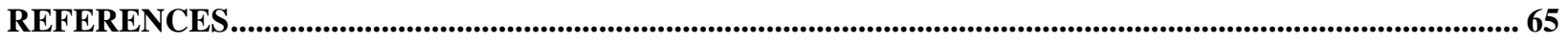




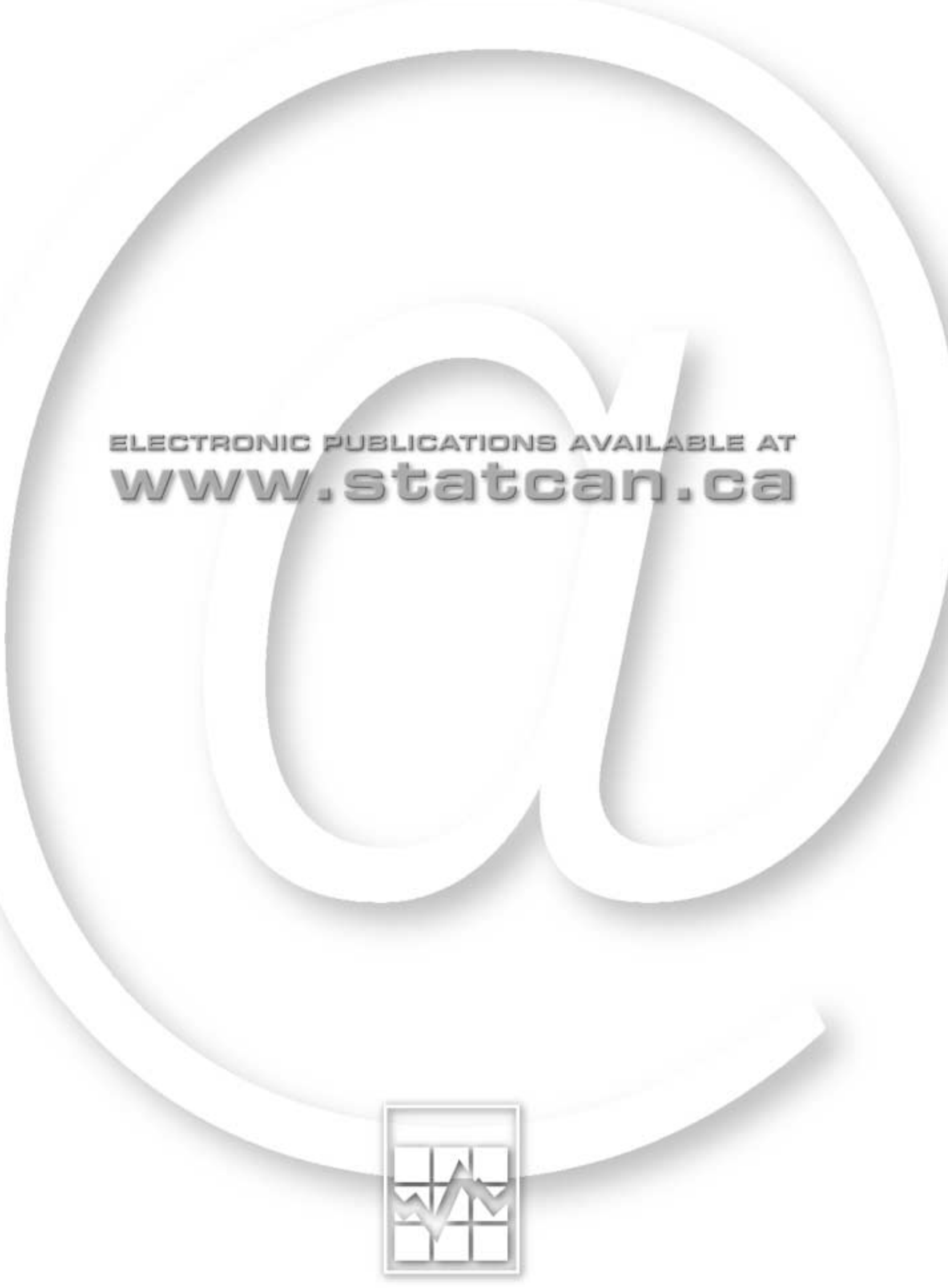




\begin{abstract}
This paper examines whether new views of the multinational that see these firms as decentralizing R\&D activities abroad to exploit local competencies accord with the activities of multinationals in Canada. The paper describes the innovation regime of multinational firms in Canada by examining the differences between foreign- and domestically owned firms. It focuses on the extent to which $R \& D$ is used; the type of $R \& D$ activity; the importance of $R \& D$ relative to other sources of innovative ideas; whether the use of these other ideas indicates that multinationals are closely tied into local innovation networks; the intensity of innovation; and the use that is made of intellectual property rights to protect innovations from being copied by others.
\end{abstract}

We find that, far from being passively dependent on R\&D from their parents, foreign-owned firms in Canada are more active in R\&D than the population of Canadian-owned firms. They are also more often involved in R\&D collaboration projects both abroad and in Canada. As expected, foreign subsidiaries enjoy the advantage of accessing technology from their parent and sister companies. While multinationals are more closely tied into a network of related firms for innovative ideas than are domestically owned firms, their local R\&D unit is a more important source of information for innovation than are these inter-firm links. Surprisingly, foreign subsidiaries also more frequently report that they are using technology from unrelated firms. Moreover, the multinational is just as likely to develop links into a local university and other local innovation consortia as are domestically owned firms. This evidence indicates that multinationals in Canada are not, on the whole, operating subsidiaries whose scientific development capabilities are truncated - at least not in comparison to domestically owned firms.

A comparison of the extent and impact of innovation activity of domestically and foreign-owned firms shows that foreign-owned firms innovate in all sectors more frequently than Canadian-owned companies in almost all size categories. They are also more likely to introduce world-first rather than more imitative innovations. Their superiority is most pronounced in the consumer goods sector. Finally, foreign-owned firms are more likely to protect their innovations with patent protection.

The paper also compares foreign subsidiaries to Canadian corporations that have an international orientation. These additional comparisons show that the two groups of multinationals are quite similar, both with regards to the likelihood that they conduct some form of R\&D and that they introduce innovations. These results indicate that it is as much the degree of globalization that affects the degree of innovativeness as the nationality of ownership.

Overall, the survey results suggest that foreign-owned firms make a significant contribution to technological progress and innovation in Canadian industry.

Keywords: innovation, research and development, intellectual property, multinationals 


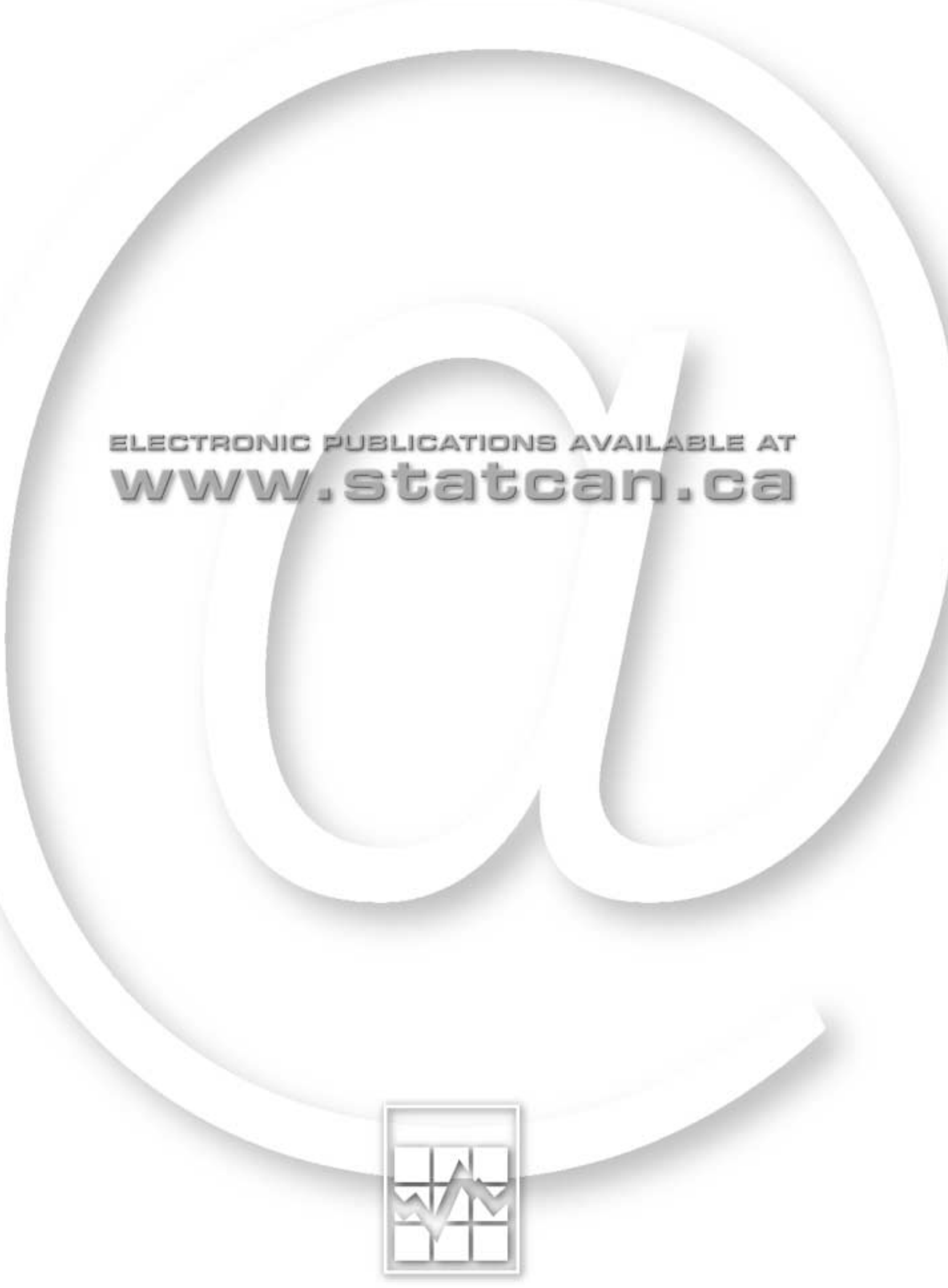




\section{Acknowledgements}

We wish to thank John Vardelas, Jorge Niosi, Ian Stewart, Stew Wells, Dick Lipsey, Tom Wilson and other participants of seminars at the Department of Finance, The National Accounts Advisory Committee at Statistics Canada and at the Centre universitaire de recherche sur la science et la technologies for constructive suggestions. 


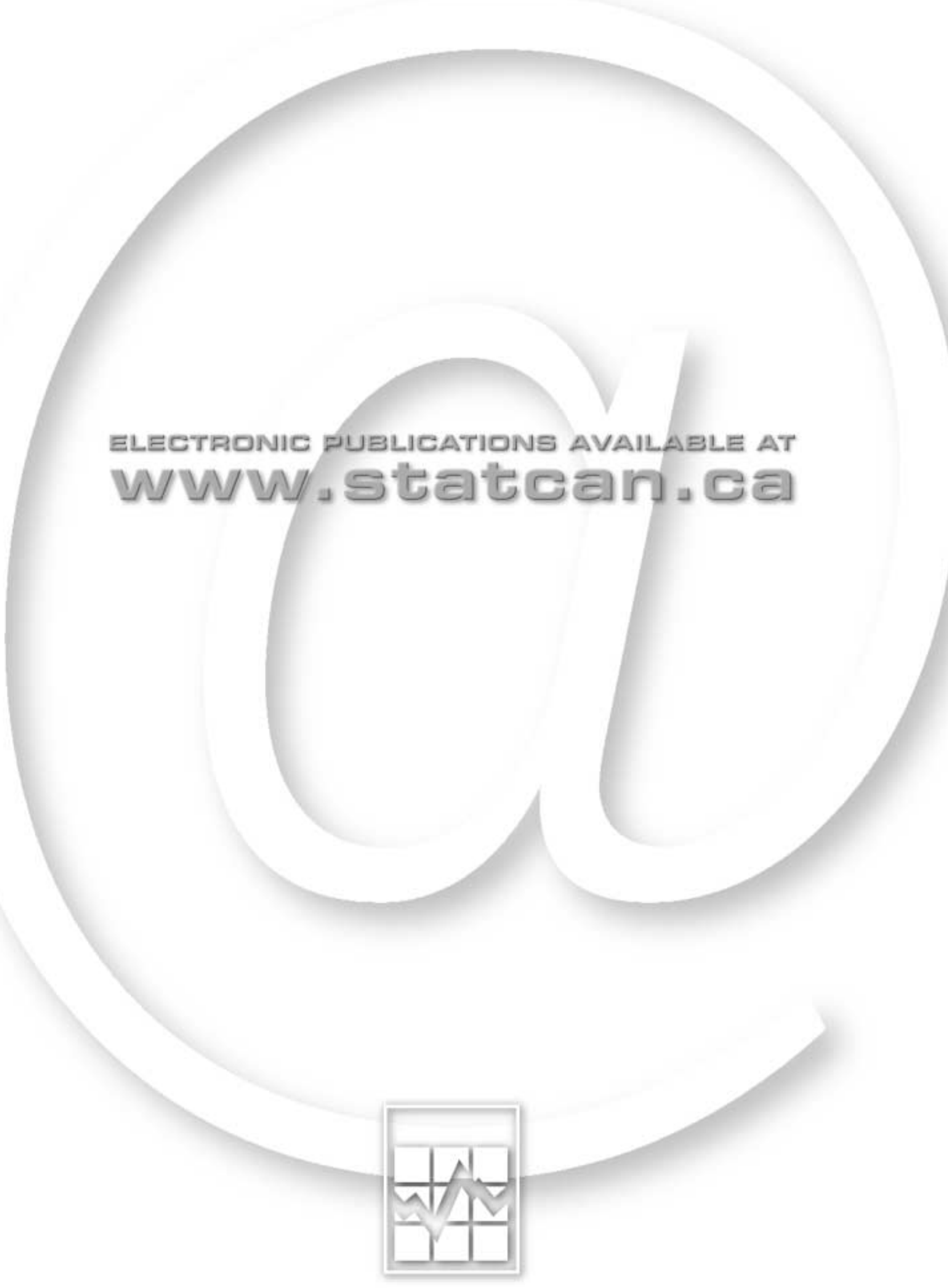




\section{Introduction}

The framework that has been used to analyze the role of multinational corporations (MNCs) in the Canadian innovation system has evolved over the last fifty years, much as these firms have evolved.

Early theories use oligopoly models that portray multinationals as entering the Canadian market to avoid tariffs (Eastman and Stykolt, 1967) or to control strategic Canadian natural resources (Aitken, 1961).

Caves $(1971,1982)$ extends this framework to argue that foreign investment by a firm just as often stems from the exploitation of a key asset, that is lumpy, indivisible, and not easily transferred from one firm to another except through foreign direct investment (FDI). This asset might involve marketing competencies (brand recognition) or scientific-knowledge arising from research and development expenditure. Asymmetric knowledge and an imperfect contractual environment that is associated with the characteristics of these assets means that the exploitation of this key asset is most efficiently done via the extension of the firm across international boundaries via direct investment.

The alternative of licensing a foreign producer can match the profitability of direct investment only in certain cases, namely where the rent-yielding advantage of the parent firm lies in an innovation of a technique or product where the know-how can be readily transferred-perhaps a simple onetime innovation. In these cases, the information on which the parent's advantage rests may be more readily transferred intact via an arm's-length sale to an unrelated firm in a foreign country. In other cases, either the information cannot be transferred without simultaneously providing entrepreneurial manpower, or the uncertainty about the value of the knowledge in the foreign market will preclude agreement on the terms of a licensing agreement that will capture the full expected value of the surplus available to the licensee.

Within this framework, foreign investment allows the host or recipient country to benefit from the specialized competency of the firm. In particular, it facilitates the transfer of the technological asset and technical know-how. But this type of foreign investment was sometimes seen to provide for little in the way of development of local capabilities outside of the multinationals' branch plants. ${ }^{1}$ This model can be described as resembling a hub and spoke system—with the key home-country asset being transferred in a single direction with little development of local capabilities at the end of each artery. Local subsidiaries were regarded as branch-plants, with the capacity to exploit the key asset but little capability to develop assets that could in turn be transferred and exploited in the world-wide operations of the parent company. The benefits of foreign investment were perceived to arise from the direct exploitation of the transferred asset and via indirect spillovers that affected domestic competitors (Dunning, 1958; Globerman, 1979, Saunders, 1980).

\footnotetext{
${ }^{1}$ A summary of this conclusion can be found in Safarian, 1973 and Britton and Gilmour (1978).
} 
The theory of the multinational that is based on the exploitation of its proprietary technological advantage can be viewed as the analogy of the linear model of innovation. Both were derived from observation and based on factual evidence. But both focus on a single representation of the facts and they tend to hide other salient processes at work or to blind observers to changing trends. The linear model of innovation tended to focus narrowly on the importance of R\&D and to underrate the effect of interactions with customers, suppliers and local scientific or technical human resources on innovation. New technology and institutions have made these linkages more important and have changed the nature of the model that has come to be used as a framework. In the same way, changes in technology and the world-trading environment have led to changes in the type of operations characteristic of multinationals.

The growing availability, importance and adoption of information technologies has reduced the need for centralization since it has made it easier to co-ordinate dispersed activities. New transportation systems and communications technologies allow for better co-ordination of the plants of large geographically diversified firms. New organizational structures for the production and distribution process, such as "just in time", shorten the time of delivery and make new types of organizations possible. Flexible design and manufacturing increase the capacity of firms to respond on short notice to orders of customers. Scientific personnel can work at geographically dispersed locations but still have their activities co-ordinated.

These changes in the way of managing manufacturing, marketing and R\&D activities have been associated with a change in the type of activities of foreign affiliates, particularly with regards to their R\&D. Foreign subsidiaries increasingly compete with their sister companies world-wide for product mandates. Recent case studies (Eden, 1994) suggest that those foreign subsidiaries in Canada that are taking an entrepreneurial approach to subsidiary management are increasingly receiving international responsibilities. As part of these initiatives, research and development activity is seen to be a key support activity and, therefore, has taken on a new role in the subsidiaries of multinationals. Activities for which Canadian subsidiaries of MNCs are responsible must be globally competitive and competitiveness requires an advanced scientific and technological foundation.

In addition to these technological and organizational developments, changes in international commercial policies and trading relations have also affected the localization and organization of R\&D and innovation activities in MNCs. These include the creation of regional trading blocs (NAFTA and the EU), the inclusion of intellectual property rights under the jurisdiction of GATT, and more recently the World Trade Organization. The decline in trade barriers that has accompanied these changes has made it easier for the MNC to take advantage of different national capabilities. Multinationals, which originally were highly focused on their country of origin, have begun to become more 'multinational', that is stateless organizations. The MNC is increasingly becoming a complex network of interactions among subsidiaries, the parent company, and their local environments. The central hub-spoke relationship is being replaced in some instances by a matrix-type organizational structure. 
These changes have been accompanied by new theoretical perspectives that reflect the increasing internationalization of R\&D activities. Multinationals based outside the United States have begun to enter the United States to take advantage of local R\&D capabilities. Foreign-owned companies accounted for $18 \%$ of total company-funded R\&D in the United States in 1995 (Serapio, 1999). In contrast with the traditional theorizing about the MNC that stressed the home-base asset-exploiting motive for foreign direct investment (FDI), the recent theories explicitly take into account the contribution to an MNC's technology and expertise from interactions with and spillovers from the human resources and institutional environment in the host country. Thus, the motives ascribed to FDI are believed to have changed since the fifties and sixties, when the prime reason for FDI in manufacturing was believed to be "jumping" over the tariff wall or transforming abundant natural resources. Low labour costs became the chief localization factor in the seventies and eighties only to be replaced by a strategy of global search for sources of technology or for new products and processes in the nineties (Eden, 1994).

Foreign-owned firms are now portrayed as needing to conduct R\&D abroad for more than one reason. The first is to exploit foreign firms' specific capabilities in the foreign environment. The second is to augment a firm's knowledge base by tapping potential spillovers from existing local resources-local firms, higher education, publicly funded or executed R\&D, and the intellectual property regime (Kuemmerle, 1999). This extension of the simple hub and spoke model to a more comprehensive matrix model of the firm can be found earlier in Teece's (1986) model of complementary assets, which argues that firms make foreign direct investments in R\&D performers in order to secure critical assets from abroad that are complimentary to the key assets held by the investing firm or to provide complimentary assets that are essential to the success of the investing firm's international operations (Serapio, 1999).

As intriguing as these new perspectives are, there has been little empirical evidence regarding their applicability to the Canadian economy (Niosi, 1999). The objective of this paper is to ask how the multinational fits into the Canadian innovation system and to ascertain which of the alternative models best describes the activities of MNCs in the early 1990s. We recognize that economic structures change slowly and, therefore, we ask whether both old and new models are needed to explain MNC activity.

The two opposing models outlined above have different predictions. The hub and spoke model suggests that the R\&D functions in Canadian subsidiaries should be relatively truncated. The mature matrix model suggests that we should expect to find that multinationals are more likely to have developed a relatively robust local $R \& D$ capacity. If local assets complement foreign assets held by a multinational, we might expect that MNCs actually are more, not less likely, to engage in local R\&D than are domestically owned firms.

Therefore, this paper examines whether the nationality of firm ownership affects the organization of R\&D activity, the sources of innovative ideas, the incidence and effects of innovation. Throughout, we compare the multinational firm operating in Canada to Canadian, domestically owned firms. By comparing the performance of the MNC to domestic corporations, we allow for the fact that technological opportunities and other structural characteristics will condition the nature of the innovation system in Canada. 
We compare the multinational firm first to all Canadian firms in order to see whether there is any indication that foreign firms are disadvantaged relative to those based in Canada. But we also examine differences between foreign multinationals and Canadian firms with a foreign orientation-those who have operations abroad or who have export sales. The latter allows us to ask whether foreign subsidiaries are disadvantaged relative to Canadian firms that successfully operate in foreign markets, what we shall refer to in this paper as domestic multinationals for the sake of brevity.

The first section deals with similarities and differences in the organization of R\&D activity between Canadian- and foreign-owned firms. It asks if foreign-controlled firms are dependent on R\&D from their parents or just as active with respect to $R \& D$ as their Canadian-owned counterparts.

The second part of the paper compares the foreign and domestic groups with respect to their sources of ideas and technology for innovation. We examine the patterns of internal and external sources of innovative ideas in both domestically and foreign-controlled firms. In doing so, we focus on two issues. The first is the extent to which the foreign-owned firm chooses to use an extensive set of information sources and thus shows that it is making as much use of local information sources as domestically owned firms. The second is the extent to which it makes such heavy use of its own affiliated partners that it neglects the development of a local R\&D capacity.

Throughout, we also investigate the extent to which technological opportunities are an important determinant of the knowledge-sourcing pattern. While this paper focuses primarily on the issue of nationality, we develop several other themes - that size of firm is closely related to the innovation pattern and that technological opportunities differ across industries and often serve to condition interfirm differences. In this vein, we ask whether there are still inherent differences by nationality type, once we have accounted for differences in the proportion of domestic- and foreign-controlled firms performing $\mathrm{R} \& \mathrm{D}$ by sector.

A comparison of the extent and impact of innovation activity of locally and foreign-owned firms concludes the paper. There has been a long-standing interest in productivity differences between Canadian- and foreign-owned firms (Safarian, 1973). Recently, Globerman, Ries and Vetinsky (1994) argue that most of the differences in labour productivity are accounted for by differences in capital intensity. But that still begs the question as to why the latter occur. Are foreign-controlled firms better able to incorporate more advanced techniques into their production process? We know that they are more likely to adopt advanced manufacturing technologies (Baldwin and Diverty, 1995, Baldwin and Sabourin, 1997; Baldwin, Rama and Sabourin, 1999). Is this because they are more adept at innovating? In the last section of the paper, we tentatively address this issue. We ask how the innovation regime that is developed in the first section of the paper is translated into innovation activity. We also ask whether foreign- and domestically owned firms make different use of intellectual property protection. 


\section{The 1993 Innovation Survey}

The data for this study come from the 1993 Survey of Innovation and Advanced Technology (SIAT). This survey was conducted by Statistics Canada in 1993 and is based on a frame of all firms possessing a Canadian manufacturing establishment. The frame is taken from Statistics Canada's Business Register. ${ }^{2}$ Firms were randomly sampled using strata that related to firm size (large versus small), region, and 2-digit SIC industry. The overall response rate to the survey was 86\%. For more details, see Baldwin and Da Pont (1996), or Baldwin (1997).

The material collected in the survey covers a number of issues relating to the innovative and technological capabilities of Canadian manufacturing firms. The questionnaire for the survey consisted of five sections: a general section covering some basic characteristics of the firm; a section on research and development; a third section on innovation; a fourth section on intellectual property rights; and a final section dealing with advanced technology.

Because of the breadth of the survey, a firm's activity in the way of innovation, research and development and intellectual property protection can be linked together. This allows us to investigate both the research and development activity, the innovation intensity, and how firms have learned to protect their intellectual property. In addition, the survey investigates the sources of ideas used by firms for innovation, the nature of impediments and the effect of innovation on the demand for labour at the firm level.

In this study, we generally report company-weighted (c-wts) that represent the population estimates derived from the survey's sample. Standard errors for data in each of the tables are presented in an appendix. We also occasionally report employment-weighted estimates. These give the percentage of employment in firms that fall in a given category. The company-weighted response will differ from the employment-weighted responses if the responses of large firms differ from small firms.

\section{Characteristics of Canadian and Foreign-owned Firms: Size and Industry Differences}

Foreign-owned firms are neither the same average size nor are they located in the same industries as domestically owned firms.

Firms with a majority of Canadian shareholders (Canadian-owned) are generally smaller than those belonging to foreign shareholders (Table 1). In the group of firms with less than 100 employees (small firms), over 90\% are Canadian-owned. In the medium-sized group (100 to 500 employees), about $72 \%$ are Canadian-owned. In the firms with over 2000 employees, only 50\% are Canadian-owned. Since the proportion of foreign-owned firms regularly increases with size, we can expect that many attributes of large firms will be associated with foreign ownership, and vice-versa. Therefore, we shall make most comparisons here between foreign-controlled and domestically owned firms within size classes.

${ }^{2}$ The Business Register maintains a listing of all establishments in the Canadian manufacturing sector. 
Since foreign ownership is really only significant for firms of medium and larger size, our comparison in this paper will concentrate on the sub-sample of the survey-those coming only from that part of the survey sample that consist of the firms referred to as the integrated portion (IP) of Statistics Canada's Business Register. These are firms that generally consist of those with more than 20 employees and exclude micro firms - those with less than 20 employees.

Foreign ownership in the manufacturing sector also varies considerably by industry. In order to examine these differences, we divide the manufacturing sector into labour-intensive industries, natural resource-based industries (separated into food and non-food), scale-based industries, product-differentiated industries, and science-based industries. ${ }^{3}$ Labour intensive industries have a high labour/capital ratio and have had higher tariff protection. Natural resource-based industries are those industries that have a high natural resource content. Scale-based industries are highly capital intensive and use advanced technologies intensively. Product differentiated industries have high advertising intensities and assets associated with brand recognition. Science-based industries rely on $\mathrm{R} \& \mathrm{D}$ assets.

Table 1. Composition of the Sample by Nationality of Ownership, by Size (\% of Larger Firms, Company Weighted)

\begin{tabular}{l|r|r|r|r|r|r}
\hline \multirow{2}{*}{$\begin{array}{c}\text { Employment } \\
\text { Size Class }\end{array}$} & \multicolumn{7}{|c}{ Manufacturing Firms Only—Majority Ownership } \\
\cline { 2 - 7 } & Canadian & \multicolumn{1}{|c|}{$\begin{array}{c}\text { Foreign } \\
\text { Shareholder }\end{array}$} & \multicolumn{1}{c}{ USA } & \multicolumn{1}{c}{ Europe } & Pacific Rim & \multicolumn{1}{c}{ Other } \\
\hline All & 83.5 & 16.5 & 10.0 & 4.8 & 1.2 & 0.6 \\
$0-20$ & 96.5 & 3.5 & 1.6 & 1.9 & 0.0 & 0.0 \\
$21-100$ & 89.9 & 10.1 & 6.5 & 2.5 & 0.9 & 0.2 \\
$101-500$ & 71.7 & 28.3 & 17.4 & 7.5 & 2.1 & 1.6 \\
$501-2000$ & 62.8 & 37.2 & 21.5 & 13.8 & 1.7 & 0.2 \\
$>2000$ & 49.5 & 50.5 & 25.5 & 22.0 & 1.5 & 1.6 \\
\hline
\end{tabular}

In natural-resource based industries that are non-food based, foreign-owned plants accounted for $62 \%$ of shipments in 1973 and $48 \%$ in 1993, a decline that is in keeping with a lessening of the importance of natural resources as an attraction for foreign investment. On the other hand, food and beverages, which is a subgroup of the natural resource sector, increased from $33 \%$ to $41 \%$ over the same period. This increase was probably the result of the increasing importance of hightech and other branded assets in this industry.

In the labour-intensive sector, foreign-owned plants accounted for 34\% of shipments in 1973 and $28 \%$ in 1993 . While foreign investment may have been encouraged by the high tariffs in these industries, it has been relatively unimportant compared to other industries and it has declined as tariffs have fallen.

In industries where size confers considerable advantages (scale-based industries), foreignownership accounted for $62 \%$ of shipments in 1973 and was relatively unchanged at $65 \%$ in 1993. Scale-based industries, with their high capital intensity require capabilities in the

\footnotetext{
${ }^{3}$ See Baldwin and Rafiquzzaman (1994) for a description of these industry groupings.
} 
technological area that are associated with the development of firm-specific assets and this has led to a relatively high and steady level of foreign ownership.

In product-differentiated industries, which are characterized by high advertising intensities and branded assets, foreign output share was $60 \%$ in 1973 and just about the same at 57\% in 1993 . Foreign penetration in those industries referred to as science-based was highest of all sectors in 1973 at $77 \%$; but it had declined to $61 \%$ by $1993 .{ }^{4}$ The decline that has occurred over time is indicative of the development of indigenous capabilities.

The high percentages of foreign ownership in the scale-based, product-differentiated and sciencebased industries confirm the advantages of foreign investment where proprietary assets exist. Corporations with proprietary technology have three ways to appropriate benefits from their technology in foreign markets. They can license their technology to foreign firms, they can export new products from the home base, or they can extend their production to foreign countries through direct investment. As the industry data show, the last alternative is frequently chosen in those industries where there is proprietary technology or related soft assets, such as brand name, marketing and distribution networks. ${ }^{5}$

Because of differences in the importance of foreign ownership, we will compare domestic and foreign firms within industries to correct for those industry characteristics that otherwise would be related to aggregate differences between foreign and domestic firms. For this purpose, we make use of a taxonomy developed by Robson, Townsend and Pavitt (1988) that divides industries into three - the core, secondary, and 'other' sectors.

The core sector (chemical, mechanical, instruments and electronics) is highly innovative, producing mainly innovations or 'technologies' used elsewhere. The secondary sector (rubber and plastics, primary metals, fabricated metals and transportation equipment) is somewhat less innovative and is more equally balanced between 'products' used in other sectors and 'processes' used in the same sector. The secondary sector uses 'technology' from the core sector but also diffuses technology via new 'products' to the other sector-though with less intensity than the core sector. The remaining industries (food and beverages, clothing, textiles, wood) are the least innovative in the sense that they originate less of the new technologies. The other sector absorbs technologies from the core and secondary sectors. Technical progress in the other sector is due in large part to the adoption of innovative 'products' that are produced by the core and secondary sectors-whether these products are material inputs such as chemicals or capital inputs such as machinery and equipment. It should be noted that, while this 'other' sector ingests innovations in the way of products and machinery from the core and secondary sector, this does not make it less innovative. Finding ways to make these products work requires ingenuity—but it probably involves a different set of skills.

The distinction between the core, secondary and other sectors is based on the degree of innovation produced in each sector and the extent to which these innovations are diffused to other sectors. These differences are related to the science-base (either R\&D or technological) of the sectors. We should, therefore, expect to find significant differences in foreign penetration

\footnotetext{
${ }^{4}$ See Baldwin and Rafiquzzaman (1994, 1995).

${ }^{5}$ See Dunning $(1992,1993)$.
} 
across these sectors because some are more likely than others to utilize the type of scientific assets that multinationals specialize in transferring from one country to another. The differences are depicted in Table 2. The core sector has the highest percentage of foreign firms (31\%). The secondary sector follows with $20 \%$. The lowest proportion (9\%) is found in industries belonging to the 'other' sector.

A breakdown by size of employment shows that the share of foreign-owned firms increases with the size of firm in each sector. In the large-firm size categories, foreign affiliates outnumber domestically owned firms in both the core and secondary sectors.

Table 2. Distribution of Firms by Ownership and Sector (\% of Larger Firms, Company Weighted)

\begin{tabular}{l|c|c}
\hline \multirow{2}{*}{\multicolumn{1}{c|}{ Sector }} & \multicolumn{2}{c}{ Majority Ownership } \\
\cline { 2 - 3 } & $\begin{array}{c}\text { Canadian } \\
\text { Shareholder }\end{array}$ & $\begin{array}{c}\text { Foreign } \\
\text { Shareholder }\end{array}$ \\
\hline All & 83.5 & 16.5 \\
Core & 68.8 & 31.2 \\
Secondary & 79.7 & 20.3 \\
Other & 91.3 & 8.7 \\
\hline
\end{tabular}

\section{Incidence and Organization of $R \& D$}

Since innovation inputs like $R \& D$ are essential to innovation outputs and the former have received more attention than the latter, we focus first on whether foreign affiliates perform $R \& D$ in Canada more or less frequently than locally owned firms. If foreign affiliates are operating as truncated branch operations, they would be expected to be less inclined to set up R\&D facilities.

Technology-policy discussions on this matter in Canada have traditionally been characterized by two opposing views on the consequences of truncation. On the one side are those who believe that owing to extensive foreign ownership, Canadian firms have easy access to new technology developed abroad and that R\&D performed in Canada is therefore not very relevant (Globerman, 1979). Others defend the need for a stronger Canadian R\&D involvement (Britton and Gilmour, 1978).

The debate on whether deficiencies exist in multinational R\&D performance has generally occurred without detailed statistics on R\&D incidence. The present survey is the most timely and complete source of information on the similarities and differences between domestically and foreign-owned firms with respect to organization of $\mathrm{R} \& \mathrm{D}$ and innovation in Canada. It also allows us to divide domestically owned firms into those with an international orientation-that operate in foreign markets, either because they possess foreign operations (production or R\&D facilities) or because of any foreign sales_-and those who are purely domestic in scope.

When we examine the differences in the probability of foreign- and domestically controlled firms conducting R\&D (Table 3), it is apparent that foreign-owned firms perform R\&D more often than domestically owned ones, taken as a whole. Since larger firms perform ongoing R\&D more 
often than the smaller ones, the employment-weighted results give higher proportions for both groups but generally do not reverse the pattern revealed by the company-weighted results. When domestically owned firms are broken into two groups, the domestic firms with an international orientation look very much like the foreign subsidiaries with their being no significant difference between the two groups. ${ }^{6}$

There is also a significant difference in the way foreign and Canadian-owned firms approach R\&D activity. Only a minority of pure domestic firms conducting any R\&D engage in ongoing R\&D (39\%). They account for less than half of employment (39\%) in the Canadian-owned segment of manufacturing. In contrast, about half of foreign firms (53\%) perform ongoing research and development and they employ almost three-quarters of employment in their segment of industry. Foreign-controlled firms are also more likely to perform ongoing R\&D than the internationally oriented domestic firms. This suggests that foreign firms operating in Canada are not truncated, at least on the basis of the performance of their domestic counterparts. ${ }^{7}$

Table 3. Incidence and Organization of R\&D (\% of Larger Firms)

\begin{tabular}{|c|c|c|c|c|c|c|c|}
\hline \multirow[b]{2}{*}{ Ownership } & \multirow[b]{2}{*}{ Weight } & & \multicolumn{5}{|c|}{ Population of R\&D Performers } \\
\hline & & $\begin{array}{c}\% \\
\text { Conducting } \\
\text { R\&D }\end{array}$ & $\begin{array}{c}\% \\
\text { Doing } \\
\text { Ongoing } \\
\text { R\&D }\end{array}$ & $\begin{array}{c}\% \\
\text { With } \\
\text { Separate } \\
\text { R\&D } \\
\text { Department }\end{array}$ & $\begin{array}{c}\% \\
\text { Performing } \\
\text { R\&D in } \\
\text { Other } \\
\text { Departments }\end{array}$ & $\begin{array}{c}\% \\
\text { Contracting } \\
\text { Out R\&D }\end{array}$ & $\begin{array}{c}\% \\
\text { Collaborating } \\
\text { on R\&D }\end{array}$ \\
\hline Foreign & Company & 88.5 & 53.4 & 44.0 & 55.1 & 19.6 & 35.3 \\
\hline All Domestic & Company & 77.4 & 42.5 & 28.0 & 63.9 & 23.3 & 20.9 \\
\hline International Domestic & Company & 85.7 & 44.7 & 30.0 & 60.5 & 23.6 & 22.1 \\
\hline Pure Domestic & Company & 66.7 & 38.8 & 24.7 & 69.5 & 22.8 & 18.9 \\
\hline Foreign & Employment & 90.3 & 74.8 & 66.0 & 48.7 & 29.5 & 57.8 \\
\hline All Domestic & Employment & 87.8 & 48.5 & 41.3 & 56.3 & 33.9 & 37.8 \\
\hline International Domestic & Employment & 94.7 & 51.2 & 43.9 & 52.8 & 33.2 & 42.9 \\
\hline Pure Domestic & Employment & 70.5 & 39.3 & 32.2 & 67.9 & 36.3 & 20.3 \\
\hline
\end{tabular}

Foreign-controlled firms are more likely to have a separate R\&D department and Canadian-owned firms tend to perform R\&D activities more often in other departments of the firm as well. But these differences are relatively minor. There are also relatively minor differences in the extent to which foreign-owned firms contract R\&D out. However, the openness of foreign subsidiaries to external sources of expertise is reflected in a more frequent participation in R\&D collaboration agreements. Multinationals take advantage of expertise from networks more frequently than domestically owned firms. Moreover, they do this more intensively than Canadian firms operating in world markets.

\footnotetext{
${ }^{6}$ Domestic multinationals are slightly lower using company-weighted estimates but slightly higher using employmentweighted estimates.

${ }^{7}$ To check whether a foreign-owned firm might be referring to its parent's R\&D capacity in the R\&D question rather than to capacity within Canada, we compared the percentage of foreign-firms reporting doing R\&D in a separate unit to the percentage of foreign firms reporting an R\&D unit in Canada (the latter came from a different question on the geographic location of production, assembly and R\&D units). They were the same.
} 
Figure 1

\section{Performed R\&D on a Regular Basis}

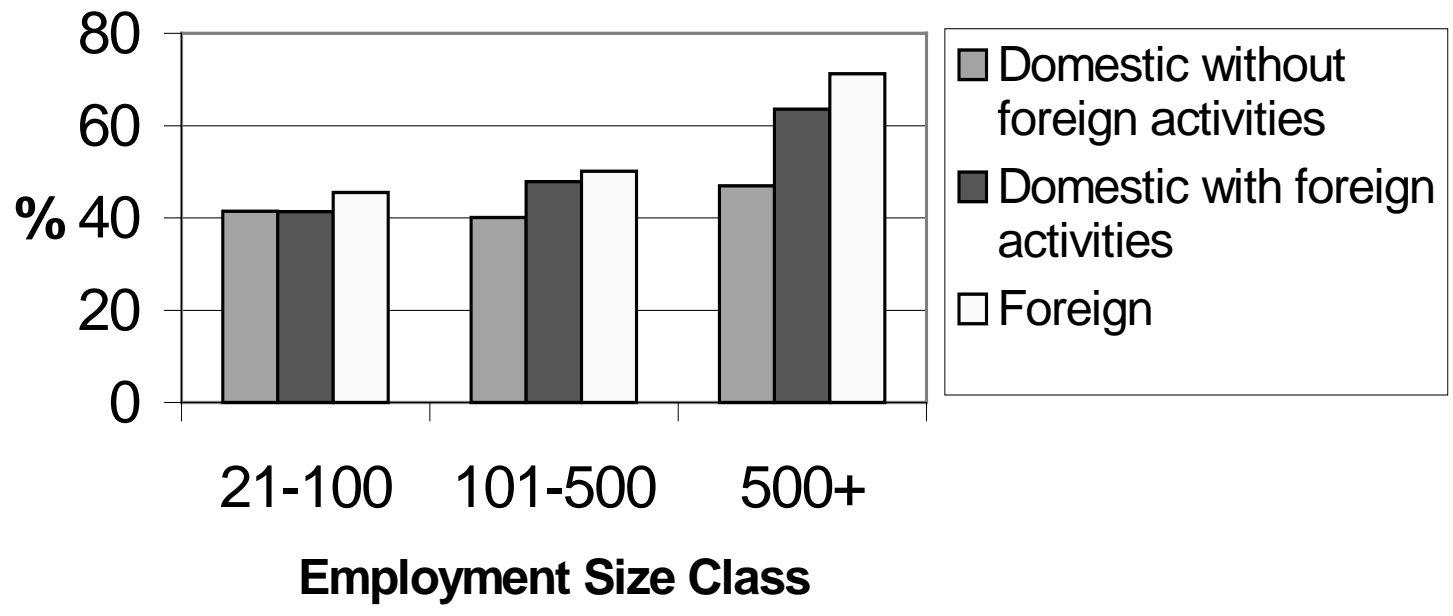

Figure 2

\section{Performed R\&D Occasionally}

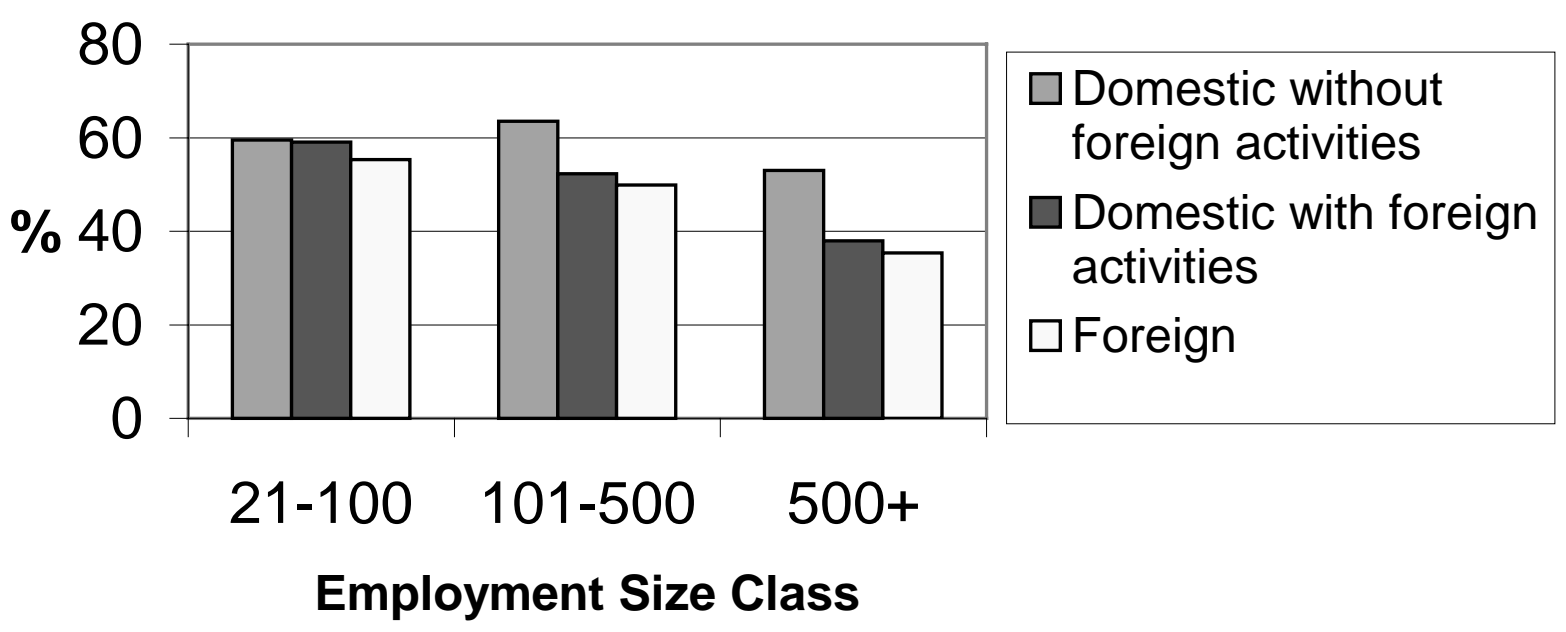


Since Canadian firms are generally smaller than their foreign counterparts, it is possible that the less intensive engagement of Canadian-owned firms in R\&D is due to their smaller size. A breakdown of the type of R\&D by size of firm shows that the proportion of smaller foreign- and domesticallyowned firms that perform ongoing (Figure 1) and occasional R\&D (Figure 2) is rather similar over the smaller size classes.

The most notable difference between the two groups occurs in the largest firm category (firms employing more than 500 employees). Only $47 \%$ of pure domestic Canadian firms and $64 \%$ of domestically owned multinationals in this size group have an ongoing R\&D program, compared to $71 \%$ of foreign-owned firms. On the other hand, domestically owned firms are more likely to conduct R\&D on an occasional basis. This holds true for both domestic firms with and without international activities - though there is much less of a difference between internationally oriented and foreign subsidiaries in the larger two size classes.

Our results then show that foreign firms are more likely to perform R\&D activity, especially compared to purely domestic firms. But these findings bear only on the incidence and not the intensity of R\&D activity. However, Holbrook and Squires (1996) have examined intensity for those firms reporting $R \& D$ expenditure and report that after controlling for size and industry, the largest Canadian-owned firms have a lower R\&D intensity (as measured by the value of $R \& D$ expenditures/sales) than foreign-owned firms. Together, these two sets of findings suggest that in the large firm size class, it is the domestic not the foreign sector that has an underdeveloped R\&D capacity.

\section{Sector Differences}

Technological opportunities are not evenly distributed over all industrial sectors and neither are foreign-owned firms. Since firms that operate in industries exploiting the latest scientific discoveries are naturally more research intensive, it may be that the location of foreign-owned firms explains the striking contrast in R\&D involvement between the largest firms of the two ownership groups.

A tabulation of R\&D involvement and organization by industry sector and by the nationality of ownership in Table 4 reveals that a higher proportion of foreign- than pure domestic firms perform ongoing R\&D in each sector. In the core sector, foreign firms and domestically owned firms with an international orientation do not differ significantly; but in the 'other' sector, foreign firms exceed both domestic groups in their likelihood that they are conducting ongoing R\&D. Two thirds of Canadian firms in the other sector do not have a separate R\&D unit and perform research and development activities in other departments. This suggests that multinationals bring specialized technological assets to all industries, not just those industries that have been characterized as the most advanced technologically. ${ }^{8}$ It also means that differences across these sectors are greater for domestic than for foreign participants.

\footnotetext{
${ }^{8}$ See Baldwin and Caves (1991) for a similar finding about differences in the effect of foreign and domestic mergers.
} 
In related work (Baldwin and Gellatly, 1999 and 2000), we have argued that the classification of industries into high- and low-tech is problematic because there are high-tech firms in every industry. The results here reinforce this point by indicating that foreign firms in all three sectors resemble one another in terms of their innovative capabilities.

The ever-increasing speed and cost of innovation is inducing firms to collaborate in order to spread the risk and cost of pre-competitive research. These collaborative agreements are most frequent in the R\&D-intensive core sector, but foreign-owned firms collaborate in all sectors more frequently than domestically owned firms and collaborate in the 'other' sector just about as much as they do in the core sector. Once again, it appears that foreign firms in the 'other' sector are exploiting technical capabilities that are firm- rather than industry-specific. Since the same cannot be said of domestic-owned firms, their technical capabilities are more likely to be related to the specific characteristics of their industries.

Table 4. Organization of R\&D by Sector and Origin of Ownership (\% of Larger Firms, Company Weighted)

\begin{tabular}{l|r|r|r|r|r}
\hline \multirow{2}{*}{ Sector / Firm Type } & \multicolumn{5}{|c}{ Population of R\&D Performers } \\
\cline { 2 - 5 } & $\begin{array}{c}\text { \% } \\
\text { Doing } \\
\text { Ongoing } \\
\text { R\&D }\end{array}$ & $\begin{array}{c}\text { \% } \\
\text { With } \\
\text { Separate } \\
\text { R\&D } \\
\text { Department }\end{array}$ & $\begin{array}{c}\text { Performing } \\
\text { R\&D in } \\
\text { Other } \\
\text { Departments }\end{array}$ & $\begin{array}{c}\text { Contracting } \\
\text { Out R\&D }\end{array}$ & $\begin{array}{c}\text { Collaborating } \\
\text { on R\&D }\end{array}$ \\
\hline $\boldsymbol{C O R E}$ & & & & & \\
Foreign & 61.7 & 50.1 & 56.2 & 19.6 & 40.3 \\
Domestic With Foreign Operations or Sales & 63.8 & 52.6 & 48.1 & 20.7 & 31.9 \\
Domestic Without Foreign Operations or Sales & 38.5 & 38.0 & 67.7 & 30.0 & 19.9 \\
SECONDARY & & & & \\
Foreign & 47.3 & 33.3 & 60.5 & 19.7 & 30.3 \\
Domestic With Foreign Operations or Sales & 4.1 & 24.7 & 66.3 & 20.7 & 19.2 \\
Domestic Without Foreign Operations or Sales & 37.0 & 23.2 & 63.6 & 20.8 & 18.6 \\
OTHER & 50.2 & 50.7 & 45.7 & 19.2 & 35.4 \\
Foreign & 36.8 & 23.7 & 62.0 & 26.8 & 19.8 \\
Domestic With Foreign Operations or Sales & 40.0 & 22.2 & 73.5 & 22.0 & 18.7 \\
Domestic Without Foreign Operations or Sales & & & & & \\
\hline
\end{tabular}

\section{Probabilistic Models of R\&D Organization}

In the previous sections, we have shown that both firm size and industry affect the nature of R\&D activity and we have presented the effect of each factor when considered by itself. In order to investigate the joint effect of size and industry and the importance of other factors like the competitive environment on the incidence and organization of $\mathrm{R} \& \mathrm{D}$, we use multivariate logit analysis here.

Each statistical model evaluates the correlates that are associated with the probability that a particular outcome occurs. In the first instance, we evaluate which variables are associated with the probability that a firm performs research and development. Here, the dependent variable takes a value of 1 if the firm performs $R \& D$ in any form; it takes a value of 0 if it does not perform R\&D at all. The next set of models estimate the probability that an R\&D-performing 
firm adopts a particular organization of its research and development activities- that it: performs ongoing $R \& D$, has a separate $R \& D$ department, performs ongoing $R \& D$ in a separate department, performs R\&D only through contract research, performs R\&D itself and contracts it out, and performs R\&D and collaborates on R\&D with other firms.

We are interested in examining how firm size, sector of location and ownership jointly affect each of these facets of the $R \& D$ process. While the hypothesis that we test changes from model to model, the set of explanatory variables is, at the beginning, identical for all models. In addition, we test the effect of competition on the choice of an R\&D system because of the importance that has been attached to the variant of the Schumpeterian hypothesis that argues that it is not just size that matters but also the competitive environment.

The following set of explanatory variables are used:

1) A binary variable identifying the nationality of a firm's ownership: DOMESTIC $=1$ if the firm is domestically owned and has neither foreign sales nor production facilities and 0 otherwise.

2) A binary variable identifying the global orientation of a domestic firm: MULTDOM=1 if the firm is domestically owned and has foreign sales or production facilities; and 0 otherwise.

3) The size of the firm is represented by four binary variables representing four separate size classes-firms from 1 to 20 employees (SIZE1); firms from 21 to 100 employees (SIZE2); firms from 101 to 500 employees (SIZE3); firms with more than 500 employees (SIZE4). Each takes on a value of 1 if the firm belongs to that sector and 0 otherwise.

4) A set of binary variables to define the three sectors. These are CORE, SECONDARY, and OTHER. Each takes on a value of 1 if the firm belongs to that sector and 0 otherwise.

5) The degree of competition that a firm faces is captured with two sets of variables. Firms in the survey were asked to identify the extent to which competition came from different regionsCanada, the United States, Europe and the Pacific Rim. In each case, firms were asked to score the degree of competition on a scale of 1 to 5 , with 0 being the least intensive and 5 the most intensive. Two variables were used here (DOMCOMP and FORCOMP). The first variable measures the degree of domestic competition and the second the degree of foreign competition from the United States. ${ }^{9}$

The various models that were estimated are:

For the population of all firms:

Model 1 Probability that a firm performs R\&D versus no R\&D

Model 2 Probability that a firm performs ongoing R\&D versus no $R \& D$

For the population of firms conducting R\&D:

Model 2a Probability that an R\&D performer does ongoing rather than occasional R\&D Model 3 Probability that an R\&D performer has a separate R\&D department

\footnotetext{
${ }^{9}$ We also experimented with an alternate variable— the number of competitors—but found no relationship.
} 
Model 3a Probability that an R\&D performer does ongoing R\&D and has a separate R\&D department

Model $4 \quad$ Probability that an R\&D performer contracts R\&D and does no R\&D himself

Model 4a Probability that a R\&D performer performs R\&D internally and contracts it out

Model 5 Probability that an R\&D performer has R\&D collaboration agreements

Coefficients of the estimated logit function associated with a particular variable are presented in Tables 5 and 7. A positive sign indicates that the variable is associated with more activity. The reference firm against which each effect is estimated is in the core sector, is a foreign firm and has 0 to 19 employees. The coefficients presented in Tables 5 and 7 allow us to evaluate the qualitative importance of each variable, but do not provide an effective mechanism to evaluate the magnitude of the effect of each. This can be done by calculating the probability values attached to each stratum. Table 6 contains the probability that some form of R\&D is performed for each of the strata represented by the dependent variables - for example for foreign as opposed to the domestic categories. In our discussion, our attention is focused on the influence of the nationality of ownership of the firm.

The probability that a firm performs any form of $R \& D$ is higher for firms that are larger, for firms that are in the core as opposed to the secondary and other sectors, and for firms that feel that they face more competition from both domestic and foreign sources (Table 5). There are substantial differences in terms of the probability of R\&D occurrence across size classes (Table 6). The smallest size class only has a $72 \%$ chance of performing R\&D, while the largest has an $89 \%$ chance. The magnitude of the differences across sectors is about the same, ranging from $76 \%$ in the other sector to $93 \%$ in the core sector.

In addition, the incidence of $R \& D$ is significantly higher for foreign-owned firms than for domestically owned firms that are purely domestically oriented (Table 5). But there is no significant difference between foreign and internationally oriented domestic firms. ${ }^{10}$ The probability of conducting R\&D for purely domestic firms is only $76 \%$ whereas it is $86 \%$ for foreign multinationals. Thus, foreign-controlled firms are at least as likely as domestically controlled firms to conduct R\&D in Canada, even after their larger size and industry location is taken into account. Nationality also has the same qualitative effect whether ongoing $R \& D$ is conducted but the difference is not significant.

\footnotetext{
${ }^{10}$ Results of earlier experiments classifying firms by ownership only (foreign versus all domestic) show that the probability of performing $R \& D$ versus no $R \& D$ (Model 1), of having a separate R\&D department (Model 3) and of having R\&D collaboration agreements is significantly higher for foreign-owned firms than for the entire domestic group of firms.
} 
Table 5. Probability Models For Various

Forms of R\&D Organizations

\begin{tabular}{|c|c|c|c|c|}
\hline \multirow{3}{*}{ Variable } & \multicolumn{4}{|c|}{ Population of All Firms } \\
\hline & \multicolumn{2}{|c|}{$\begin{array}{c}\text { Any R\&D } \\
\text { Model } 1 \\
\end{array}$} & \multicolumn{2}{|c|}{$\begin{array}{l}\text { Ongoing R\&D } \\
\text { Model } 2 \mathrm{a}\end{array}$} \\
\hline & \multicolumn{4}{|c|}{ Coefficients and $(\mathrm{P}>\mid \mathrm{t})$} \\
\hline Intercept & 1.23 & .005 & -0.84 & .023 \\
\hline SIZE2 & 0.53 & .031 & 0.75 & .015 \\
\hline SIZE3 & 1.00 & .002 & 0.96 & .004 \\
\hline SIZE4 & 1.21 & .007 & 1.69 & .000 \\
\hline DOMESTIC & -0.62 & .041 & -0.17 & .482 \\
\hline MULTDOM & 0.07 & .810 & 0.06 & .777 \\
\hline DOMCOMP & 0.57 & .030 & -0.18 & .401 \\
\hline FORCOMP & 0.61 & .004 & 0.35 & .054 \\
\hline SECONDARY SECTOR & -0.90 & .006 & -0.63 & .002 \\
\hline OTHER SECTOR & -1.39 & .000 & -0.91 & .000 \\
\hline \multirow{4}{*}{$\begin{array}{l}\text { Log Likelihood } \\
\text { Number of Observations } \\
\text { F } \\
\text { P>F }\end{array}$} & \multirow{2}{*}{\multicolumn{2}{|c|}{1320}} & \multirow{2}{*}{\multicolumn{2}{|c|}{1320}} \\
\hline & & & & \\
\hline & & 10.07 & & 8.03 \\
\hline & & .0000 & & .0000 \\
\hline
\end{tabular}

Table 6. Probability of R\&D

\begin{tabular}{l|c|c}
\hline \multirow{2}{*}{\multicolumn{1}{c|}{ Variable }} & Any R\&D & $\begin{array}{c}\text { Ongoing } \\
\text { R\&D }\end{array}$ \\
\cline { 2 - 3 } & \multicolumn{2}{|c}{ Probability (\%) } \\
\hline SIZE1 & 72 & 22 \\
SIZE2 & 81 & 37 \\
SIZE3 & 87 & 42 \\
SIZE4 & 89 & 60 \\
DOMESTIC & 76 & 38 \\
MULTDOM & 86 & 38 \\
FOREIGN & 86 & 38 \\
CORE SECTOR & 93 & 54 \\
SECONDARY SECTOR & 84 & 39 \\
OTHER SECTOR & 76 & 32 \\
DOMCOMP + 1 st.dev. & 85 & 38 \\
DOMCOMP - 1 st.dev & 79 & 38 \\
FORCOMP + 1 st.dev & 86 & 42 \\
FORCOMP - 1 st.dev. & 78 & 34 \\
\hline
\end{tabular}

Table 7. Probability Models for Various Forms of R\&D Organization

\begin{tabular}{|c|c|c|c|c|c|c|}
\hline \multirow{3}{*}{ Variables } & \multicolumn{6}{|c|}{ Population of R\&D Performers } \\
\hline & Ongoing & $\begin{array}{c}\text { Separate } \\
\text { R\&D } \\
\text { Department }\end{array}$ & $\begin{array}{l}\text { Ongoing and } \\
\text { Separate R\&D } \\
\text { Department }\end{array}$ & $\begin{array}{c}\text { No In-house } \\
\text { R\&D and } \\
\text { Contracts Out }\end{array}$ & $\begin{array}{c}\text { R\&D } \\
\text { In-house and } \\
\text { Contracts Out }\end{array}$ & Collaborative \\
\hline & Model 2a & Model 3 & Model 3a & Model 4 & Model 4a & Model 5 \\
\hline Intercept & -0.22 & -0.10 & 0.90 & $-2.00^{\mathrm{a}}$ & $-2.21^{\mathrm{a}}$ & $-1.17^{\mathrm{a}}$ \\
\hline SIZE2 & $0.64^{\mathrm{c}}$ & 0.32 & 0.01 & -0.23 & 0.29 & 0.53 \\
\hline SIZE3 & $0.75^{\mathrm{b}}$ & $0.80^{\mathrm{b}}$ & 0.43 & -0.44 & 0.64 & $0.80^{\mathrm{b}}$ \\
\hline SIZE4 & $1.52^{\mathrm{a}}$ & $1.49^{\mathrm{a}}$ & $1.44^{\mathrm{b}}$ & -0.57 & $1.09^{\mathrm{c}}$ & $1.65^{\mathrm{a}}$ \\
\hline DOMESTIC & 0.01 & -0.19 & -0.45 & -0.45 & $0.63^{\mathrm{c}}$ & -0.15 \\
\hline MULTDOM & 0.34 & -0.16 & -0.21 & 0.91 & 0.37 & -0.24 \\
\hline DOMCOMP & -0.44 & $-0.50^{b}$ & -0.11 & 0.23 & -0.38 & $-0.68^{\mathrm{a}}$ \\
\hline FORCOMP & 0.18 & -0.03 & -0.13 & $-0.62^{b}$ & -0.04 & $0.37^{\mathrm{c}}$ \\
\hline Secondary sector & $-0.51^{b}$ & $-0.89^{\mathrm{a}}$ & $-0.98^{\mathrm{a}}$ & $0.67^{\mathrm{c}}$ & $-0.62^{b}$ & -0.35 \\
\hline Other sector & $-0.68^{\mathrm{a}}$ & $-0.89^{a}$ & $-0.87^{\mathrm{a}}$ & $0.77^{\mathrm{c}}$ & -0.47 & -0.34 \\
\hline Log Likelihood & -730.4 & -638.1 & -329.2 & -396.3 & -369.1 & -565.1 \\
\hline Number of observations & 1094 & 1094 & 510 & 1094 & 1094 & 1094 \\
\hline
\end{tabular}

Note: $\quad$ Significance level $\mathrm{a}=0.01, \mathrm{~b}=0.05, \mathrm{c}=0.1$ 
Once firms conduct $R \& D$, there are fewer variables that determine how they do it, whether it is ongoing, in a separate $R \& D$ department, whether it is ongoing and has a separate $R \& D$ department, whether it is contracted out, or whether collaboration occurs (Table 7). In almost all cases, larger firms are more likely to engage in these activities (the one exception being the case of contracting out and not doing R\&D in-house). But the degree of competition and the nationality of ownership rarely have a significant effect on the type of R\&D process that is undertaken. Again a notable exception is that purely domestic firms are more likely to contract out R\&D.

\section{R\&D Collaboration Partnerships}

R\&D activity is increasingly performed in partnerships, alliances and joint ventures. These forms of collaborative research efforts are motivated by the necessity to reduce the cost, to speed up the innovation and the product cycle, and to share the risk involved in discovering, inventing and innovating (Niosi, 1995).

When all R\&D performers in the survey report their partnerships, foreign affiliates report that they have collaborative partners almost twice as often as pure domestic firms (Table 3). Their likelihood of collaboration is higher than for domestic multinationals as well. This difference could, however, be unduly influenced by the large number of small firms included in the Canadian-owned sub-sample. Like many other aspects of the organization of R\&D, setting up a partnership requires information, time and money, all in short supply in the smallest firms. However, even after controlling for the size of the firms, foreign-owned firms report R\&D partnerships more frequently than Canadian ones in all size categories, though the differences are only marked in the largest size group (Figure 3).

In order to separate out the different influences on R\&D collaboration, we estimated the probability of a firm having a collaboration agreement using a logit regression (model 5 in Table 7). The results show that after the size of the firm, the extent foreign competition and the industry sector are taken into account, foreign affiliates are more likely to participate in R\&D partnership than Canadian-owned firms though these differences are not statistically significant.

Facing foreign rather than domestic competitors also increases the probability of R\&D collaboration. The relationship between the ownership structure, competitive environment and the size of the firm on the probability of an R\&D partnership provides evidence that the conduct of firms in a given industry sector is affected by the technological opportunity inherent in and the structural characteristics of the industry.

R\&D collaboration is not a substitute for own research and development activity but a complement to it (Cohen and Levinthal, 1989). Firms conduct their own research in order to develop in-house expertise that enables them to absorb the research output of co-operative research, to develop the in-house expertise so as to contribute to co-operative projects and to monitor the development of science and technology in a particular field (Mowery and Rosenberg, 1989). We should, therefore, expect to find that those firms that are more likely to conduct R\&D are also more likely to engage in collaborative ventures. 
The findings of the present survey support this view. The fact that foreign affiliates have a higher propensity to conduct $R \& D$ in a separate department and to participate in partnerships than do purely Canadian companies are two related aspects of their innovation strategy. In addition to the capabilities that arise from their conducting $R \& D$ in Canada, foreign affiliates bring technological and other intangible assets of their parent multinational enterprise to an R\&D partnership. Their 'entry ticket' to co-operative ventures is thus provided by their 'family' connection and the 'membership fee' by their ongoing R\&D (Kumar, 1995).

Foreign innovators establish research partnerships just as frequently as do domestic innovators, not only abroad, but also in Canada, e.g. with customers, universities and research institutions and other partners. In Figure 4, we present the percentage of firms reporting a partnership with a particular type of partner (customers, suppliers, etc.). In addition, we subdivide this information by the nationality of the partner (domestic and foreign). The results show that foreign firms have collaborative agreements more frequently than Canadian ones with foreign partners and often more frequently with domestic partners. For example, $41 \%$ of foreign-owned innovating firms have a partnership with customers, but only $33 \%$ of domestic partners do. Part of this difference is the result of differences in terms of partnerships with customers located abroad-29\% and $22 \%$ for foreign and domestic firms, respectively. This pattern also exists for R\&D institutions and Canadian universities. In contrast, domestic firms are more likely to have domestic collaborative agreements with domestic suppliers and domestic competitors.

In summary, we conclude that multinationals operating in Canada are not operating as truncated firms without a research and development capacity. While they are larger and tend to be more concentrated in the high-tech sectors, they are as likely to possess an R\&D capacity, and to develop separate $R \& D$ facilities as their domestic counterparts. Canadian firms with an international orientation approach foreign firms with regard to their likelihood of performing $\mathrm{R} \& \mathrm{D}$, but they lag slightly behind with respect to their tendency to conduct ongoing $\mathrm{R} \& \mathrm{D}$. Another important conclusion is that foreign-owned firms do not collaborate less frequently than domestically owned firms with Canadian partners (customers, R\&D institutions, universities and colleges and other partners). Thus, as far as R\&D collaboration is concerned, there is no evidence in support of the once popular argument (Britton and Gilmour, 1978: Britton, 1980) that foreignowned firms do not develop links in Canada and are thus responsible for a truncated pattern of corporate innovative behaviour in Canadian manufacturing. 
Figure 3

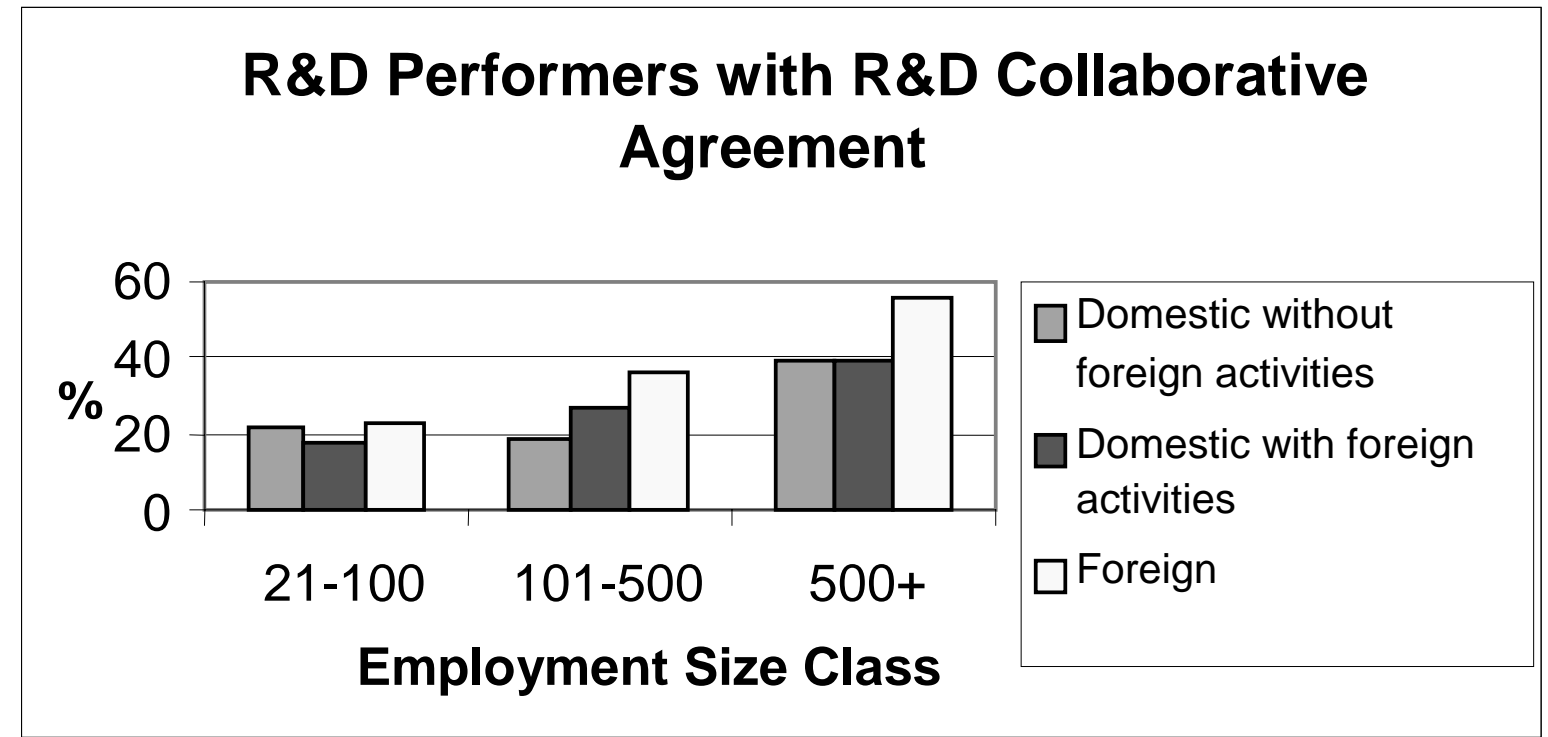

Figure 4

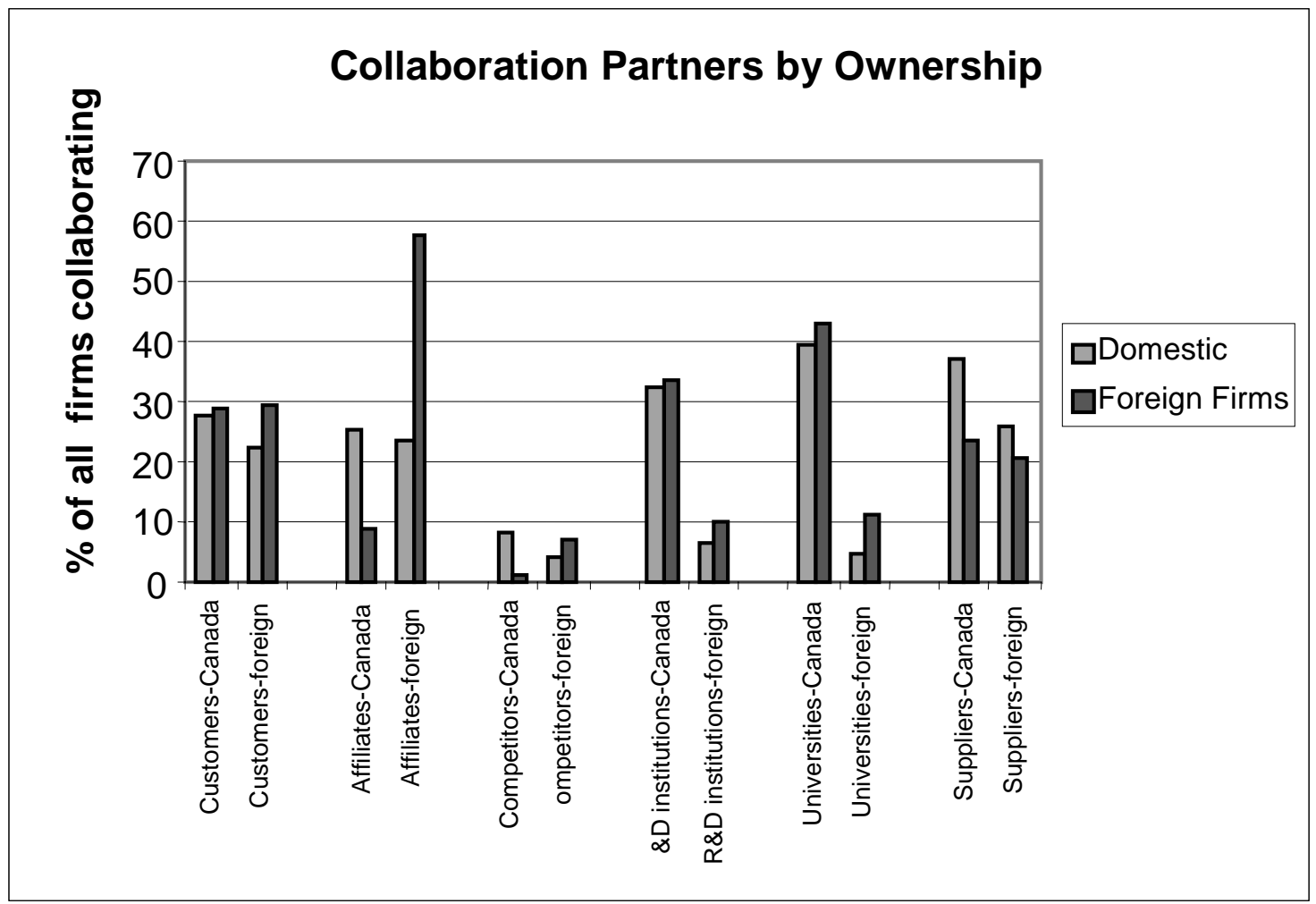




\section{Sources of New Ideas and Inspiration for Innovation}

Interactions between foreign affiliates in Canada and their parent and sister companies provide a fertile ground for innovative ideas and inspiration. Increasingly, the R\&D activity of foreign affiliates serves a double purpose. On the one hand, it serves to adapt technologies developed by their group of companies to local conditions. On the other hand, it acts as a corporate antenna for capturing new ideas and technological spillovers for potential use in their MNC's innovation activity.

Yet R\&D provides only one of the sources of ideas for innovation. R\&D is neither necessary nor sufficient for innovation. In some sectors, sources such as management partially substitute for it. In some cases, it is combined with external sources to facilitate the ingestion of outside ideas. This section examines the importance that is attributed to both inside sources of ideas for innovation, including R\&D, and outside sources, such as affiliates. It builds on the previous section by asking whether multinationals not only rely on their sister firms but whether there is any indication that this reliance occurs to the detriment of the R\&D capacity of the firm.

This section also provides an indirect measure of the importance of the R\&D unit. The previous section provided evidence only on the incidence of R\&D, though its description of the type of organization associated with the establishment of an $R \& D$ facility provided a measure of the capacity of the firm. Firms that perform ongoing rather than only occasional R\&D are perceived by themselves to be more competitive. In this regard, multinationals were found to be more likely to be conducting $\mathrm{R} \& \mathrm{D}$ but also to be more likely to be conducting ongoing $\mathrm{R} \& \mathrm{D}$, which involves a greater commitment to the innovation process. In this section, we therefore ask whether there is evidence to suggest that really very little is contributed by local R\&D units to the local innovation process of multinationals. We do so by comparing the importance attributed to R\&D as opposed to other sources. If the multinational attributes little importance to its R\&D unit as a source of ideas, especially compared to the importance it attributes to information coming from its parent company, then we shall infer that the local R\&D operation is little used.

The personal interactions and exchanges between member firms of the multinational enterprise potentially provide a favourable environment for innovation. The rigid, hierarchical organizational structure still typical of some multinational enterprises may, however, prevent this potential advantage from being fully realized. Thus it remains an empirical question whether most foreign affiliates in Canada succeed in realising this potential advantage over their locally owned counterparts.

Since Canadian firms are on average smaller than foreign affiliates, observed differences in the source of innovative ideas between the two groups may simply reflect differences in the organization of smaller and larger firms. There is some evidence of this in the type of internal sources that are used by foreign and domestically owned firms. R\&D personnel is the most frequently mentioned internal source of innovative ideas in foreign-owned firms, while Canadianowned firms rely more on management for inspiration (Table 8). 
Of equal interest is whether there are differences between Canadian and foreign firms once we allow for industry effects. There do not appear to be. Once industry differences are accounted for (Table 8), there are few consistent differences between the foreign and the domestic groups for management, sales, and production as internal sources of innovative ideas. But it is the case that foreign firms report a significantly greater tendency to use R\&D facilities in the 'other' sector.

This difference in the emphasis given to $\mathrm{R} \& \mathrm{D}$ also exists if we compare foreign firms to those domestic firms with an international orientation (Figure 5). The differences are largest in the 'other' sector.

In conclusion, except in the area of $\mathrm{R} \& \mathrm{D}$, foreign firms look very similar to domestically owned firms when it comes to their source of ideas. Previously, we found that foreign firms were generally more likely to have an R\&D unit compared to domestically owned firms. They are also considerably more likely to make use of their R\&D unit as a source of ideas for innovation. 
Table 8. Internal sources of innovative ideas by origin of ownership by sectors (\% of innovating large firms, company weighted)

\begin{tabular}{|c|c|c|c|c|c|c|c|c|}
\hline \multirow[b]{3}{*}{ SECTORS } & \multicolumn{8}{|c|}{ SECTORS } \\
\hline & \multicolumn{2}{|c|}{ ALL } & \multicolumn{2}{|c|}{ CORE } & \multicolumn{2}{|c|}{ SECONDARY } & \multicolumn{2}{|c|}{ OTHER } \\
\hline & $\begin{array}{c}\text { Canadian } \\
\text { Shareholder }\end{array}$ & $\begin{array}{c}\text { Foreign } \\
\text { Shareholder }\end{array}$ & $\begin{array}{c}\text { Canadian } \\
\text { Shareholder }\end{array}$ & $\begin{array}{c}\text { Foreign } \\
\text { Shareholder }\end{array}$ & $\begin{array}{c}\text { Canadian } \\
\text { Shareholder }\end{array}$ & $\begin{array}{c}\text { Foreign } \\
\text { Shareholder }\end{array}$ & $\begin{array}{c}\text { Canadian } \\
\text { Shareholder }\end{array}$ & $\begin{array}{c}\text { Foreign } \\
\text { Shareholder }\end{array}$ \\
\hline Management & 53.5 & 48.9 & 46.5 & 39.9 & 53.1 & 60.1 & 57.9 & 47.7 \\
\hline $\mathrm{R} \& \mathrm{D}$ & 40.6 & 55.2 & 60.3 & 67.9 & 45.7 & 41.7 & 25.9 & 52.6 \\
\hline Sales \& Marketing & 43.6 & 40.6 & 48.4 & 40.4 & 41.0 & 44.6 & 42.3 & 34.2 \\
\hline Production & 36.5 & 33.7 & 21.1 & 20.5 & 49.8 & 43.6 & 37.7 & 43.1 \\
\hline Other & 3.3 & 3.9 & 0.6 & 2.2 & 2.5 & 5.6 & 5.4 & 4.6 \\
\hline
\end{tabular}

Table 9. Main external sources of innovative ideas, by industry sectors and by origin of ownership (\% of innovating firms, companyweighted)

\begin{tabular}{|c|c|c|c|c|c|c|c|c|}
\hline \multirow[b]{3}{*}{ SECTORS } & \multicolumn{8}{|c|}{ SECTORS } \\
\hline & \multicolumn{2}{|c|}{ ALL } & \multicolumn{2}{|c|}{ CORE } & \multicolumn{2}{|c|}{ SECONDARY } & \multicolumn{2}{|c|}{ OTHER } \\
\hline & $\begin{array}{c}\text { Canadian } \\
\text { Shareholder }\end{array}$ & $\begin{array}{c}\text { Foreign } \\
\text { Shareholder }\end{array}$ & $\begin{array}{c}\text { Canadian } \\
\text { Shareholder }\end{array}$ & $\begin{array}{c}\text { Foreign } \\
\text { Shareholder }\end{array}$ & $\begin{array}{c}\text { Canadian } \\
\text { Shareholder }\end{array}$ & $\begin{array}{c}\text { Foreign } \\
\text { Shareholder }\end{array}$ & $\begin{array}{c}\text { Canadian } \\
\text { Shareholder }\end{array}$ & $\begin{array}{c}\text { Foreign } \\
\text { Shareholder }\end{array}$ \\
\hline Suppliers & 28.6 & 27.4 & 22.1 & 28.4 & 25.0 & 16.6 & 34.6 & 44.4 \\
\hline Clients \& Customers & 48.3 & 37.9 & 50.7 & 37.4 & 51.0 & 43.3 & 45.3 & 29.4 \\
\hline Related Firms & 9.0 & 39.6 & 10.3 & 41.9 & 8.4 & 36.6 & 8.6 & 40.1 \\
\hline Competitors & 29.9 & 19.3 & 26.1 & 18.2 & 35.3 & 22.8 & 29.0 & 15.1 \\
\hline $\begin{array}{l}\text { Government Regulations \& } \\
\text { Standards }\end{array}$ & 8.9 & 5.8 & 15.5 & 4.8 & 12.2 & 4.9 & 3.0 & 9.7 \\
\hline Consultants & 13.8 & 10.6 & 13.6 & 14.9 & 22.0 & 6.6 & 9.0 & 8.7 \\
\hline Trade Fairs & 18.6 & 12.9 & 10.2 & 15.5 & 13.4 & 10.2 & 26.6 & 12.1 \\
\hline Professional Publications & 13.2 & 10.7 & 12.1 & 18.2 & 8.1 & 5.2 & 17.0 & 5.2 \\
\hline
\end{tabular}




\section{How Important a Source of Innovative Ideas Are Foreign Parents and Sister Companies of Foreign-owned Firms?}

A principal advantage of the presence of foreign-owned firms in Canada is their access to the knowledge and technology pool of their parent and sister companies abroad (Globerman, 1979). Confirming this, related firms were mentioned most frequently as an external source of innovation ideas by $40 \%$ of foreign-owned firms (Table 9). In comparison, only $9 \%$ of Canadian-owned firms reported a related firm as their source of innovation ideas. Differences in the importance of related firms extend to both groups of domestically owned firms - those with and without an international orientation (Figure 6). Access to the knowledge, information and contacts provided by related firms constitute the principal difference between the external sources of innovative ideas of locally and foreign-owned firms.

This finding does not mean that the connection with related firms leaves foreign firms with underdeveloped facilities in other areas. Local initiatives of foreign subsidiaries that develop their own path-dependent process of learning-by-doing and innovation are as important as are intracompany linkages. Even though foreign-owned firms reported their parent or sister firms often as the source of inspiration for innovation, their own R\&D was even more important. It is reported as a source of innovation ideas by 55\% of foreign-owned firms-significantly more often than inspiration from their parent or sister companies $(40 \%)$. This difference is even greater in the core sector. $R \& D$ is mentioned as a source of ideas by more than two out of three foreign-owned firms in the core sector, significantly more frequently than ideas from the parent or sister companies (42\%). A breakdown by firm-size category (not presented here) indicates that in the core sector, only smaller foreign-owned firms rely on their parents for ideas more frequently than on R\&D. Those employing more than 100 persons report that their own $R \& D$ is a more frequent source of innovative ideas than their parent or sister firms.

Foreign-controlled firms also use information from customers about as frequently as they make use of ideas from their parents. The creation and maintenance of a dense set of local linkages lessens the parent's influence over the subsidiary (Ghoshal and Bartlett, 1990). Thus, foreign firms draw their ideas for innovation from a variety of sources and not exclusively from their parent's corporate headquarters. 
Figure 5

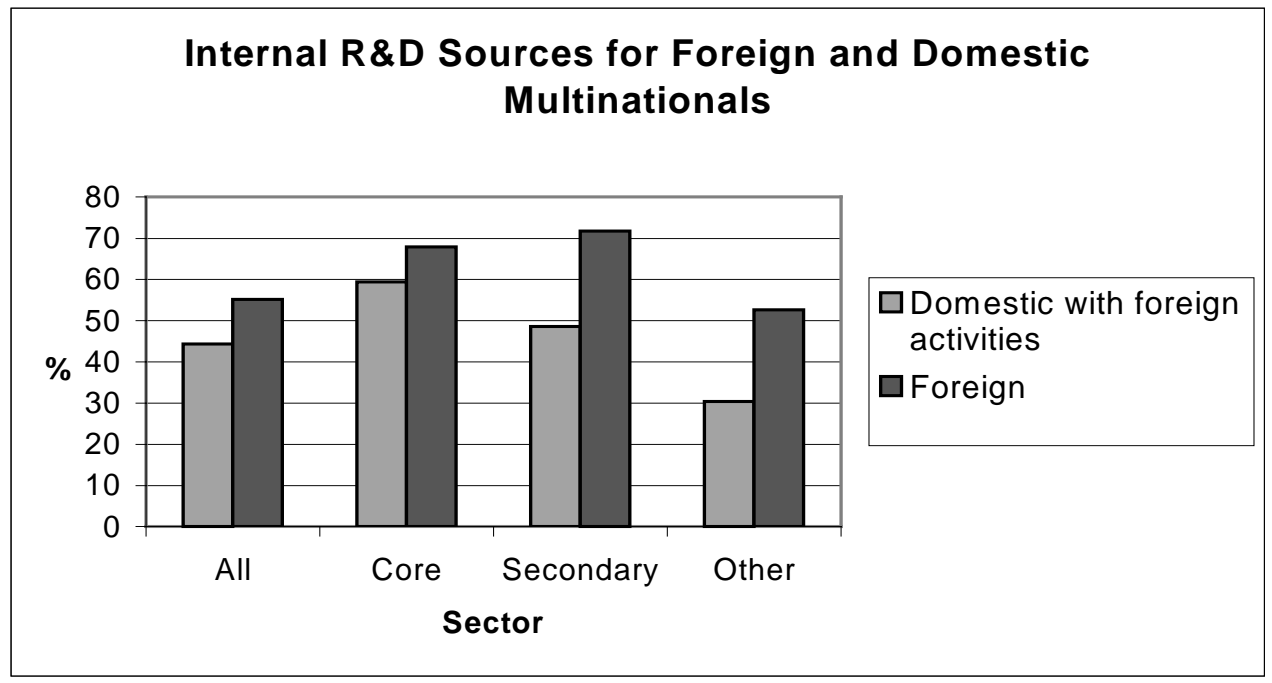

Figure 6

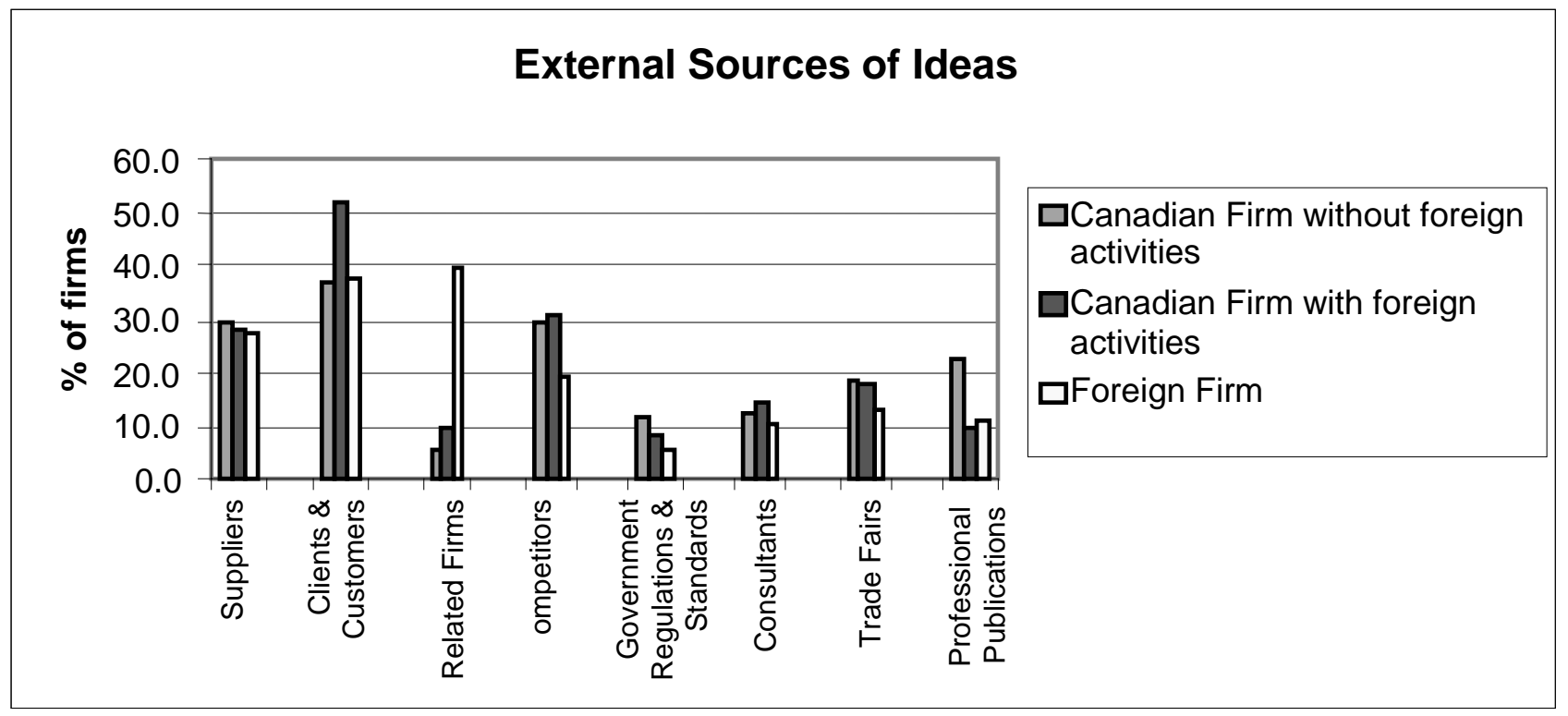


In order to investigate differences across different types of foreign affiliates, these firms were separated into those that used innovation ideas received from their parent or sister company and those that did not. These two types will be referred to here as dependent and independent foreign affiliates (Table 10, columns 1 and 2, respectively).

Dependent affiliates implement ideas received from parent companies and suppliers. These are channelled and adapted to Canadian conditions more often by affiliates' management and R\&D departments than by their suppliers, and sales and marketing services. Technologically dependent affiliates are also less receptive to innovative ideas from their Canadian customers. Their information sourcing fits the image of the more traditional 'branch plant' operation.

The second group of technologically more independent foreign affiliates rely relatively more on their own R\&D, in that it is the most important source of ideas. The second most important group providing innovative ideas are customers, and sales \& marketing departments. Management is relatively unimportant. The independent affiliates, therefore, not only have a more developed R\&D department but they are also closer to their customers, which are credited to be the source of ideas for innovations in one out of every two of these firms.

The degree of reliance on ideas from related firms is not associated with the size of foreign affiliates, but size is a significant factor determining the strategy of information sourcing in other areas. As was shown previously, there is a close relationship between the size of firm and the reliance on management or R\&D for innovation ideas. Small and medium-sized foreign-owned firms are, therefore, more likely to fit the characteristics of the 'dependent' type than larger ones. Since reliance on internal $R \& D$ is also positively associated with the technological intensity of the industry sector and with the originality of innovation, one could expect to find a higher proportion of 'dependent' affiliates in the technologically less intensive secondary and 'other' sectors.

Table 10. Main Sources of Innovation Ideas Reported by Foreign Affiliates Broken Down by Whether Innovation Ideas Come From Related Firms (\% of Larger Innovating Firms, Company Weighted)

\begin{tabular}{lr|r}
\hline \multicolumn{1}{c}{ Source of Idea } & \multicolumn{2}{c}{ Idea From Related Firms } \\
\hline Management & Used & Did not use \\
R\&D & 67.3 & 36.9 \\
Production & 48.8 & 59.3 \\
Sales \& marketing & 40.2 & 29.4 \\
Suppliers & 34.3 & 44.8 \\
Clients and customers & 38.9 & 20.0 \\
\hline
\end{tabular}




\section{Internal and External Sources of Technology}

Innovation is accompanied by problems associated with accessing technology. Firms solve some of these with their own resources, others with the help of suppliers, clients and related firms, with consultants, or with other private and public sources of technical information.

Foreign-owned subsidiaries are part of a multinational corporation that can offer its corporate members many technical services that the mostly unaffiliated Canadian-owned firms must either provide for themselves, contract out or find in the public domain.

This difference is confirmed by the finding that 'related firms' are an important source of technology for foreign-owned firms but not for domestic firms (Table 11). Domestically owned firms generally do not have the same options of drawing technical assistance from affiliated firms. They make up for it by relying more on their suppliers and customers.

Despite the importance of the technological contribution provided by related firms to their subsidiaries in Canada, foreign-owned firms still develop local capabilities as a source for ideas in this area. They use own research about as often (33\%), and experimental development more frequently (51\%), than technology from related firms (32\%). Notwithstanding differences in the access to their parent's technology, the most significant single difference between foreign and domestically owned firms is that the former relies more often than the latter on production engineering.

In summary, foreign affiliates, far from relying exclusively on their parent and sister companies, tap a larger variety of internal and external sources in Canada than most of their Canadian counterparts in their quest for technology.

\section{Transfer of Technology}

One of the raisons d'être of multinational firms is their advantage in internalising activities in areas where market transactions are inefficient and costly. Among the most important of these is the transfer of technology. Multinational firms prefer to exploit their technological lead through foreign direct investment as compared to other forms of technology transfer such as licensing (Caves, 1971).

Easy and efficient transfer of technology between parent and sister companies is one of the principal advantages of foreign ownership (Teece, 1977). Ease of technology transfer is accomplished by multinationals through a continuous transfer of technology rather than costly one-time contracts with all their attendant negotiation costs. For several reasons, technology transfer is more difficult when arm's-length contracts have to be negotiated. First, asymmetric information leads to high negotiation and monitoring costs. Secondly, one-time contracts need to take into account the need to transfer knowledge about improvements in technology, which are often an important part of the technological process. Without codicils that allow for these improvements, the technology that is transferred rapidly becomes obsolete. 
Table 11. Internal and Principal External Sources of Technology, by Ownership and by Industry Sectors (\% of Larger Innovating Firms, Company-weighted)

\begin{tabular}{|c|c|c|c|c|c|c|c|c|}
\hline \multirow[b]{2}{*}{ SECTORS } & \multicolumn{2}{|c|}{ ALL } & \multicolumn{2}{|c|}{ CORE } & \multicolumn{2}{|c|}{ SECONDARY } & \multicolumn{2}{|c|}{ OTHER } \\
\hline & $\begin{array}{c}\text { Canadian } \\
\text { Shareholder }\end{array}$ & $\begin{array}{c}\text { Foreign } \\
\text { Shareholder }\end{array}$ & $\begin{array}{c}\text { Canadian } \\
\text { Shareholder }\end{array}$ & $\begin{array}{c}\text { Foreign } \\
\text { Shareholder }\end{array}$ & $\begin{array}{c}\text { Canadian } \\
\text { Shareholder }\end{array}$ & $\begin{array}{c}\text { Foreign } \\
\text { Shareholder }\end{array}$ & $\begin{array}{c}\text { Canadian } \\
\text { Shareholder }\end{array}$ & $\begin{array}{c}\text { Other Foreign } \\
\text { Shareholder }\end{array}$ \\
\hline Research & 31.3 & 33.0 & 57.4 & 48.9 & 28.1 & 18.0 & 17.0 & 24.4 \\
\hline Experimental Development & 52.7 & 50.8 & 68.3 & 54.3 & 57.5 & 52.8 & 40.2 & 40.2 \\
\hline Production Engineering & 47.8 & 65.0 & 39.8 & 53.1 & 59.0 & 85.3 & 46.2 & 56.5 \\
\hline Related Firm & 11.0 & 32.0 & 7.7 & 36.5 & 11.4 & 32.1 & 12.8 & 22.5 \\
\hline Unrelated Firm & 14.2 & 19.6 & 8.6 & 20.2 & 5.9 & 16.0 & 22.4 & 24.1 \\
\hline Consultants and Service Firms & 17.0 & 11.3 & 12.0 & 9.9 & 20.0 & 10.2 & 18.4 & 15.9 \\
\hline Publications & 8.6 & 8.8 & 17.3 & 13.7 & 0.5 & 7.1 & 7.9 & 1.4 \\
\hline Trade Fairs \& Conferences & 13.8 & 13.6 & 9.8 & 17.7 & 10.5 & 13.1 & 18.1 & 5.9 \\
\hline Government Laboratories & 3.6 & 4.4 & 4.4 & 4.6 & 1.9 & 6.8 & 4.1 & 0.0 \\
\hline University Laboratories & 3.3 & 7.8 & 4.9 & 9.9 & 2.0 & 6.5 & 3.0 & 5.8 \\
\hline Customer Firm & 15.9 & 8.5 & 9.4 & 5.6 & 20.8 & 7.1 & 17.2 & 16.6 \\
\hline Supplier Firm & 33.5 & 29.2 & 22.7 & 25.5 & 25.0 & 33.1 & 45.2 & 30.6 \\
\hline
\end{tabular}


The survey results on the nature of technology transfer confirm that substantial differences exist between foreign and domestically controlled firms with regards to technological transfer (Table 12). Foreign-owned firms have an advantage over locally owned firms in that they more frequently arrange a continuous transfer of technology, listed respectively by $52 \%$ and $30 \%$ of respondents from each group. Domestically owned firms have more difficulties in arranging a continuous technology transfer and use one time transfer more often than foreign subsidiaries ( $27 \%$ and $19 \%$, respectively). These differences confer a competitive edge to foreign affiliates in sectors where the rate of technological change is fastest.

Since domestically owned firms use one-time contracts more frequently for technology transfer, their contracts are more often subject to conditions that need to be spelled out in detail in these types of contracts; however, these differences are not very significant. Technology transfer contracts signed by domestically owned firms more frequently contain clauses conferring a specific right to sell and to use in manufacture. The difference between the two ownership groups is negligible in other areas. About one-third of contracts in each case restrict manufacturing or sales of transferred technology to a specified territory.

Table 12. Type of Transferred Technology and Associated Restrictions (\% of Firms, Companyweighted)

\begin{tabular}{l|r|r}
\hline \multirow{2}{*}{ Type of Transfer } & \multicolumn{2}{|c}{ Ownership } \\
\cline { 2 - 3 } & Canadian Shareholder & Foreign Shareholder \\
\hline Part of continuous transfer & 29.8 & 52.0 \\
One-time transfer & 27.4 & 19.0 \\
Cross-licensing & 2.1 & 4.9 \\
Right to manufacture & 33.8 & 32.6 \\
Right to sell & 33.0 & 18.0 \\
Right to use in manufacturing & 30.7 & 24.0 \\
Right to use patents & 19.8 & 20.8 \\
Right to use industrial designs & 16.0 & 12.9 \\
Right to use trade marks & 12.8 & 14.2 \\
Right to use trade secrets & 19.1 & 21.1 \\
Other rights & 8.5 & 9.6 \\
\hline
\end{tabular}

The survey also offers an insight into differences in the channels through which innovations are spread to the rest of the economy. The survey investigated whether an innovation was sold (that is transferred) to other firms. Domestic- and foreign-owned firms transfer or sell their innovations by different means. The large foreign-owned firms transfer their innovations primarily through sales of capital goods while domestically owned firms do so through sales of intermediate products. 
Since new or improved capital goods are among the most important vehicles of technological change, the large foreign affiliates generate process innovation in downstream industries. This is also corroborated by the fact that a larger proportion of foreign firms introduce new production techniques $(68.3 \%)$ than locally owned firms $(57 \%)$. Since foreign-owned firms tend to introduce world-first innovations more frequently than locally owned firms, they also transfer intellectual property more frequently.

\section{Impediments to Innovations}

Because of the extent of foreign ownership in the Canadian manufacturing sector, the previous sections have focused on the type of innovation system possessed by the Canadian affiliates of multinationals. It finds that foreign-owned firms have an advantage in that they rely heavily on foreign affiliates, and that they have developed local innovative capacities in the form of R\&D units as well as local supply networks.

Foreign innovation rates are influenced not just by problem of developing local R\&D units; they also are affected by other problems - the extent to which local labour markets do not provide the type of skills required, the effectiveness of technology information networks, or the extent to which government regulations present obstacles.

Obstacles reported by both domestic- and foreign-owned firms are remarkably similar (Table 13). The most frequent one is the lack of skilled personnel, but here foreign firms are slightly less likely to have this problem than domestically owned firms, probably because they can draw on their affiliates for help. Foreign firms are slightly more likely to report problems with lack of information on markets and on technology, but these differences are not significant.

A sectoral breakdown reveals some sector-specific differences. Foreign firms operating in the secondary sector have more difficulties than their Canadian counterparts, particularly with regards to inter-firm co-operation and government standards.

The situation is reversed in the 'other' sector, where Canadian-owned firms report impediments to innovation more frequently, except for government standards and regulations. Complaints of foreign affiliates regarding government standards and regulations were particularly frequent $(51 \%)$ in the 'other' sector. 
Table 13. Impediments to Innovation (\% of Large Firms by Sector and Ownership)

\begin{tabular}{|c|c|c|c|c|c|c|c|c|}
\hline \multirow{2}{*}{ SECTORS } & \multicolumn{2}{|c|}{ ALL } & \multicolumn{2}{|c|}{ CORE } & \multicolumn{2}{|c|}{ SECONDARY } & \multicolumn{2}{|c|}{ OTHER } \\
\hline & $\begin{array}{c}\text { Canadian } \\
\text { Shareholder }\end{array}$ & $\begin{array}{c}\text { Foreign } \\
\text { Shareholder }\end{array}$ & $\begin{array}{c}\text { Canadian } \\
\text { Shareholder }\end{array}$ & $\begin{array}{c}\text { Foreign } \\
\text { Shareholder }\end{array}$ & $\begin{array}{c}\text { Canadian } \\
\text { Shareholder }\end{array}$ & $\begin{array}{c}\text { Foreign } \\
\text { Shareholder }\end{array}$ & $\begin{array}{c}\text { Canadian } \\
\text { Shareholder }\end{array}$ & $\begin{array}{c}\text { Foreign } \\
\text { Shareholder }\end{array}$ \\
\hline Lack of Skilled Personnel & 48.7 & 40.8 & 40.0 & 37.9 & 42.8 & 41.1 & 56.9 & 46.3 \\
\hline Lack of Information on Technology & 30.0 & 34.4 & 30.1 & 37.3 & 32.6 & 38.9 & 28.4 & 19.8 \\
\hline Lack of Information on Markets & 28.0 & 31.2 & 36.3 & 43.0 & 26.5 & 30.6 & 24.5 & 6.6 \\
\hline Lack of External Technological Services & 15.9 & 11.8 & 19.6 & 6.8 & 9.2 & 17.1 & 18.0 & 12.9 \\
\hline Barriers to Interfirm Coop. & 14.8 & 14.5 & 16.9 & 10.9 & 8.8 & 24.8 & 17.4 & 3.2 \\
\hline Barriers to University Coop. & 6.3 & 4.1 & 5.8 & 7.3 & 5.2 & 2.6 & 7.2 & 0.0 \\
\hline Government Standards \& Regulations & 21.3 & 30.3 & 26.5 & 23.3 & 17.6 & 27.5 & 20.8 & 50.8 \\
\hline Other & 22.3 & 17.0 & 20.2 & 18.3 & 25.6 & 18.5 & 21.5 & 11.2 \\
\hline
\end{tabular}

Table 14. Firms that Introduced, or Were in the Process of Introducing, an Innovation During the Period 1989-91, by Ownership Class and by Size (\% of Large Firms)

\begin{tabular}{l|c|c|c|c}
\hline \multicolumn{1}{c}{ Ownership } & \multicolumn{3}{c}{ Employment Size Class } \\
\cline { 2 - 5 } & $21-100$ & $101-500$ & 501 plus & All \\
\hline Canadian without foreign operations or sales & 27 & 33 & 39 & 29 \\
Canadian with foreign operations or sales & 45 & 48 & 64 & 47 \\
Foreign & 56 & 39 & 72 & 52 \\
\hline
\end{tabular}


Table 15. Distribution of Innovations by Ownership, Size of Firm and Sector (\% of Large Firms)

\begin{tabular}{|c|c|c|c|c|c|}
\hline \multirow[t]{2}{*}{ Sector } & \multirow[t]{2}{*}{ Ownership } & \multicolumn{4}{|c|}{ Employment Size Class } \\
\hline & & $21-100$ & $101-500$ & $500+$ & All \\
\hline \multirow[t]{3}{*}{ Core } & Canadian without Foreign Operations & 40 & NA & NA & 52 \\
\hline & Canadian with Foreign Operations & 62 & 69 & 75 & 66 \\
\hline & Foreign & 67 & 45 & 77 & 60 \\
\hline \multirow[t]{3}{*}{ Secondary } & Canadian without Foreign Operations & 27 & 35 & NA & 28 \\
\hline & Canadian with Foreign Operations & 40 & 45 & 72 & 44 \\
\hline & Foreign & 64 & 41 & 70 & 57 \\
\hline \multirow[t]{3}{*}{ Other } & Canadian without Foreign Operations & 25 & 24 & 41 & 26 \\
\hline & Canadian with Foreign Operations & 41 & 42 & 51 & 42 \\
\hline & Foreign & 18 & 30 & 69 & 36 \\
\hline
\end{tabular}

Table 16. Product, Process and Combination of Product and Process Innovation Features By Ownership and Size (\% of larger innovating firms, company -weighted)

\begin{tabular}{|c|c|c|c|c|}
\hline Size & Ownership & Product & Process & Product \& Process \\
\hline \multirow[t]{2}{*}{ All } & Canadian & 39.1 & 49.0 & 53.4 \\
\hline & Foreign & 45.5 & 60.5 & 57.7 \\
\hline \multirow[t]{2}{*}{$21-100$} & Canadian & 37.3 & 46.8 & 53.3 \\
\hline & Foreign & 41.2 & 59.9 & 59.6 \\
\hline \multirow[t]{2}{*}{$101-500$} & Canadian & 38.1 & 47.2 & 54.9 \\
\hline & Foreign & 41.6 & 64.2 & 51.9 \\
\hline \multirow[t]{2}{*}{$501-2000$} & Canadian & 51.0 & 62.5 & 64.1 \\
\hline & Foreign & 41.1 & 58.2 & 59.7 \\
\hline \multirow[t]{2}{*}{$2000+$} & Canadian & 38.4 & 82.5 & 57.5 \\
\hline & Foreign & 78.0 & 57.2 & 64.2 \\
\hline
\end{tabular}




\section{Do Canadian-owned Firms Innovate More or Less than Foreign Affiliates?}

The impact of foreign ownership on the structure and performance of Canadian industry has often been at the centre of controversy. Our overview of R\&D activities, sources of innovation and the method used to transfer technology suggests that foreign-owned firms are more likely than domestically owned firms to build a stock of proprietary knowledge, which is one of the essential conditions for successful innovation strategy.

These differences are reflected in innovation activity. Foreign firms exploit their superior innovation potential and they are more likely to introduce innovations than their domestic counterparts. The foreign-owned rate of innovation is $52 \%$, while the rate for domestically owned firms with no foreign orientation it is just $27 \%$ and for domestically owned firms that are internationally oriented, it is 47\%.11 Thus, domestically owned firms with an international orientation are not very different in terms of their innovativeness than multinationals. Innovation gaps are largest between the group of firms with an international orientation (both foreign and domestic) and those who serve only domestic markets (Table 14).

The difference in the innovation rate varies across size categories, across sectors, and industry groups. Foreign-owned firms innovate more frequently than all domestically owned firms in the smallest and largest size categories; but not in medium-size companies (100 to 500 employees), where Canadian-owned multinationals have an edge over their foreign counterparts (Table 14).

When the proportion of innovating firms is broken-down by industrial sector and by size of firm (Table 15), the previously revealed relationship between the size of firm, nationality and innovation incidence remains broadly unchanged. The purely domestic firms generally innovate less than both types of multinationals across all size classes. There are no consistent differences between the two types of multinationals (Figure 7). In the core sector, domestic multinationals are more innovative overall but not in every size class; in the secondary sector, the domestic multinationals are less innovative overall but this stems primarily from differences in the smallest size class. In the two largest size classes, there is little difference between the two groups.

\section{Do Foreign-owned Firms Introduce Process Innovations More Often Than the Canadian- owned Firms?}

A distinguishing feature of the innovation activity of foreign-owned firms in Canada that was noted in the Economic Council's innovation survey was the tendency of foreign-owned firms to introduce process innovations more often than Canadian-owned companies (De Melto et al., 1980). However, the Council's survey covered only a limited number of manufacturing sectors. The present survey provides information on whether this result holds across the manufacturing sector, not just for process innovations but also for product innovations that are made without a

\footnotetext{
${ }^{11}$ This sample, as all others in this paper, uses just the integrated portion of Statistics Canada's Business Register group, which is generally larger than 20 employees.
} 
change in process technology and product innovations that are accompanied by changes in technology (See Table 16).

In comparison with their domestically owned counterparts, foreign-owned firms are relatively more likely to introduce pure process innovations than product innovations (both without and with a change in manufacturing technology). While foreign-owned firms introduced all three types of innovations more frequently than the locally owned firms, the largest differences between foreign- and domestically owned firms occur for process innovations. The tendency of foreign-owned firms to introduce pure process innovations somewhat more often than Canadianowned companies can also be found within each industry sector.

There are, however, some differences in this pattern when the relationship is broken down by size of the firm. Small and medium size foreign-owned firms introduce process innovations more frequently than comparable Canadian-owned firms. The opposite is true for the two largest size categories, where Canadian-owned firms introduce pure process innovations more frequently than foreign-owned ones. A possible explanation of this pattern is that Canadian and foreignowned firms of similar size in terms of Canadian employment (or sales) are not really comparable. A foreign affiliate employing say less than 500 persons in Canada may be related to a parent company abroad that is several times its Canadian size. If so, the affiliates' performance in Canada reflects in many respects the structure, conduct and performance of a much larger parent firm and cannot be readily compared to a Canadian-owned company of a similar size. As evidence of this, size affects the introduction of process innovation more for Canadian-controlled firms than for foreign-controlled affiliates. Smaller foreign affiliates can viably introduce pure process innovations because their cost is spread over the volume of production of the whole multinational enterprise.

The ownership-specific innovation features (not presented here) emphasize and illustrate the difference between the two groups. On the one hand, close to one third of domestically owned firms specialize in product innovations with functional novelties. On the other hand, almost two thirds of foreign affiliates list the major characteristic of their innovation as involving an improvement in production techniques.

\section{Originality of Innovations}

Another significant difference between domestically and foreign-owned firms is that the latter introduce a higher proportion of world-first and Canada-first innovations (Table 17). This difference applies to both purely domestic firms and multinational domestic firms (Figure 8). The imitative innovations that were neither world-firsts nor Canadian-firsts are introduced more frequently by Canadian-owned firms.

This pattern is partly but not entirely related to the sectoral distribution of foreign ownership and the average size of foreign affiliates. Since foreign affiliates are concentrated in the core sector and are on average larger than their Canadian-owned counterparts, it is to be expected that they will display characteristics of the core sector and of large firms, i.e. a heavier involvement in R\&D and a corresponding higher proportion of original innovations. 
However, there are other factors at work because a comparison by sector shows that foreign-owned firms tend to introduce more original innovations in all sectors. About one in three affiliates in the core sector introduced a world-first innovation, compared to less than one in four Canadian-owned firms. There are also major differences in the secondary sector.

Only in the imitative 'other " sector is the rate of world-first innovations that are created by both ownership groups about equal. ${ }^{12}$ Moreover, these results are not just caused by larger firm size-as a comparison of the company and employment-weighted results in Table 17 shows.

According to the conventional wisdom, foreign-owned subsidiaries introduce new technology only after it has been first introduced in the country of origin of the parent company. Accordingly one would expect foreign affiliates to be in the forefront introducing Canada-first innovations, thus confirming their role as the prime means of transferring foreign technology to Canadian industry. This is the case. Foreign affiliates report a higher proportion of those innovations than locally owned companies in all sectors. However, it should be noted that this superiority disappears when innovation rates, weighted by employment, are compared. These are higher for domestically controlled than for foreign firms. Thus, it is the smaller foreign firms operating in Canada who are most likely to be bringing in technology that has already been introduced abroad. A similar comparison of the company and employment-weighted estimates for world-firsts indicates that it is the larger firms that are introducing the most innovative products simultaneously in Canada and abroad.

This provides evidence of the increasing interdependence of the largest foreign affiliates operating in Canada. One effect of the world-wide improvements in communication and transportation infrastructures is the development of increasing linkages among actors, both within and across national boundaries. World-wide companies are increasingly striving to combine advantages of development and application of 'central innovations'-innovations that are borne from the union of key capabilities of a large MNC, which must remain at the headquarters to both protect core competencies of the company and to achieve economies of specialization and scale in $\mathrm{R} \& \mathrm{D}$, and local innovations, which are essential to meet the needs of the various national environments in which the company operates (Bartlett and Ghoshal, 1989).

Finally, it should be noted that imitative innovations, which are neither world- firsts nor Canadafirsts, are introduced in all sectors more frequently by Canadian-owned firms. The contribution of domestically owned firms to diffusion of technological change within Canada is negatively correlated with R\&D intensity. It is least pronounced in the core sector and most notable in the 'other' sector.

\footnotetext{
${ }^{12}$ Even though these results concern only the most profitable innovation per firm, they would not be reversed by taking into account the number of innovations introduced by each firm. Foreign-owned firms introduced on average more innovations per firm than Canadian-owned ones.
} 


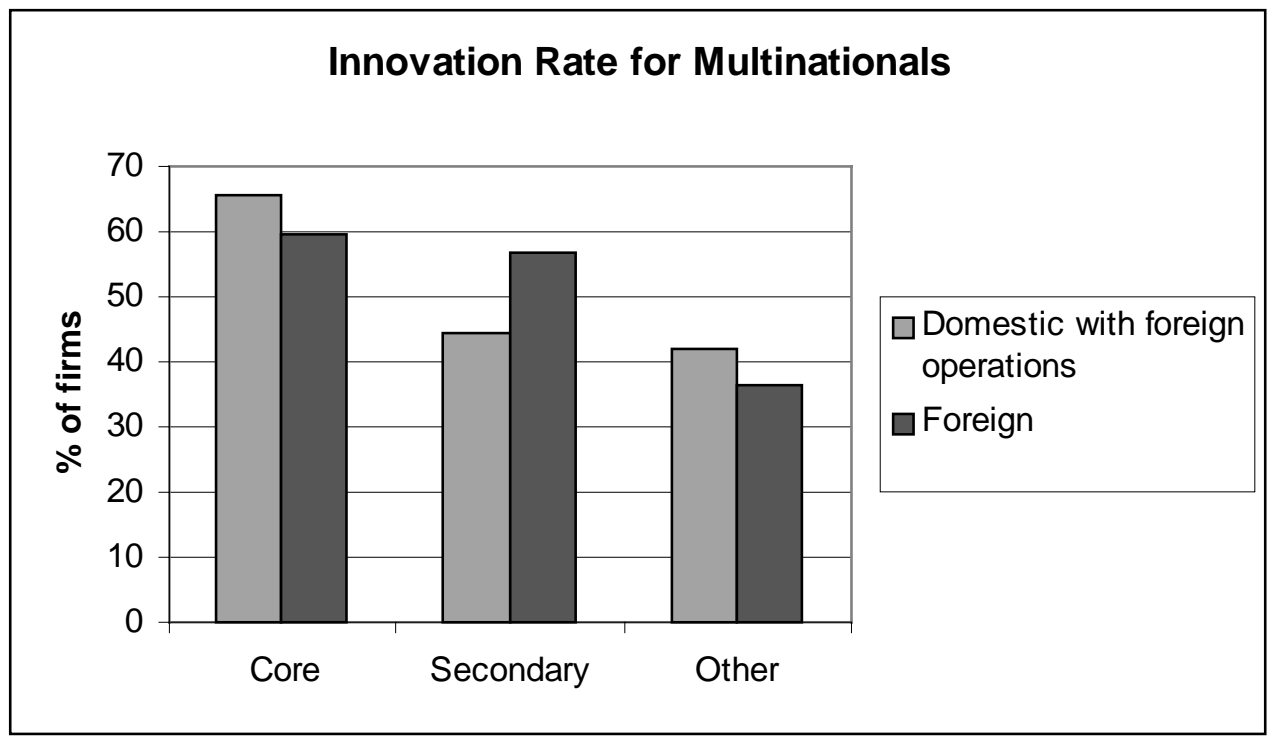

In summary, the evidence unequivocally supports the hypothesis that foreign-owned firms contribute significantly to technological progress in Canadian industry. A further break down of the data by size of firm could reveal that part of the lead of foreign-owned firms over Canadianowned firms is related to their larger size and other activities like R\&D. This issue is investigated at greater length in Baldwin, Hanel and Sabourin (2000). However, a finding that other factors account for most foreign versus domestic differences would not invalidate the conclusion that foreign-owned firms make a greater contribution to industrial innovation in this country than their domestically owned counterparts that have no international orientation. In addition to the "direct" contribution of foreign-owned firms through R\&D and innovation in Canada, foreignowned firms also contribute through the development of a cadre of skilled technical and managerial personnel and spillovers that accrue to domestic firms.

\section{Figure 8}

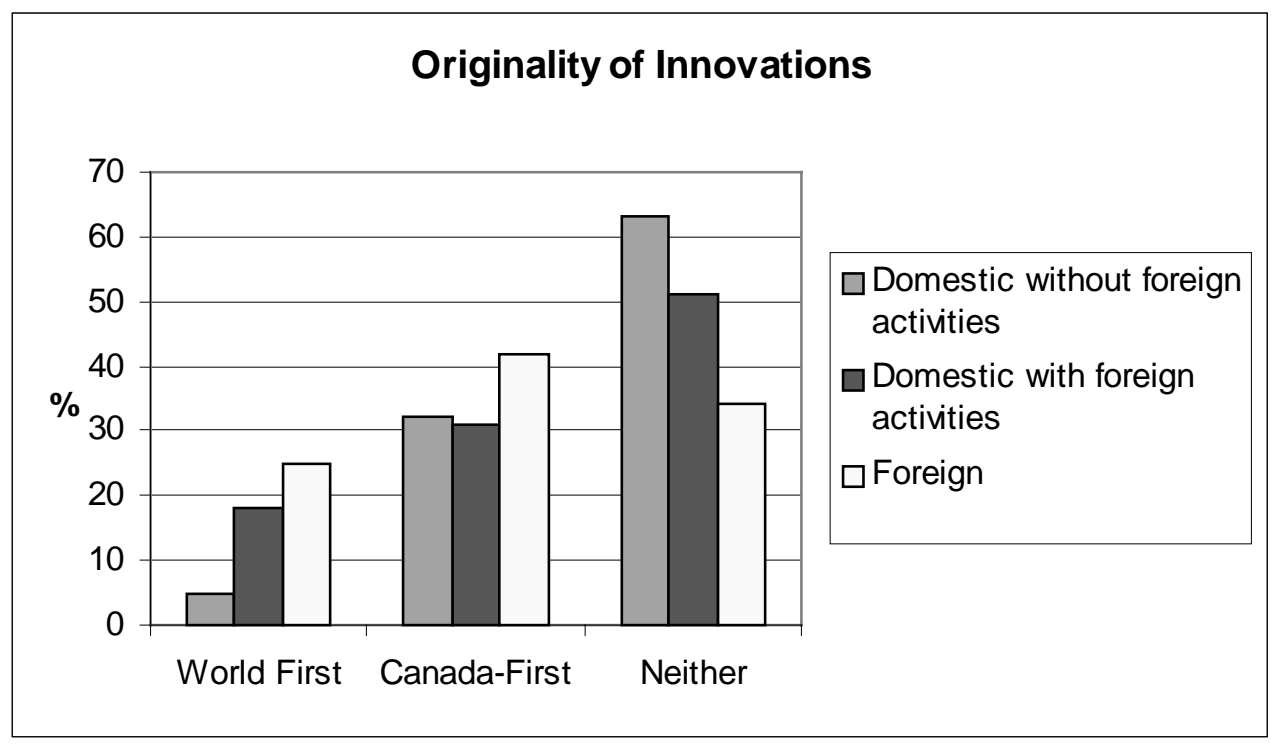




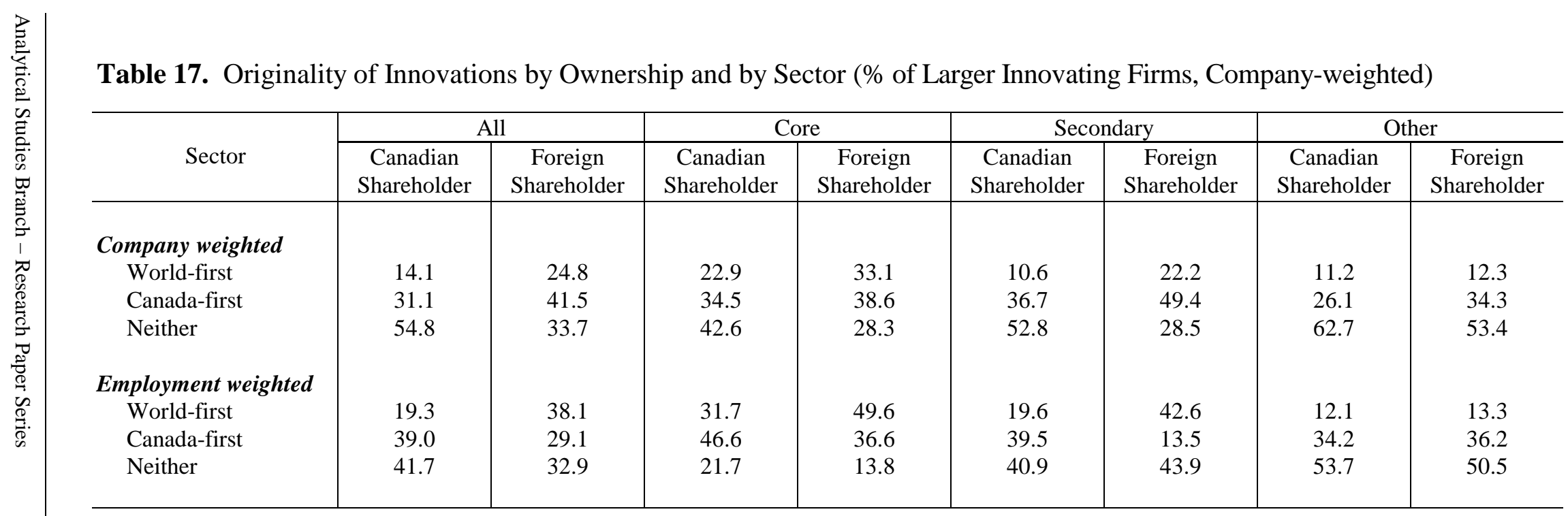

Table 18. Number of Innovations Introduced and in Progress by Type of Innovation and By Ownership (\% of Firms)

\begin{tabular}{|c|c|c|c|c|c|c|}
\hline \multirow[b]{2}{*}{ Ownership } & \multicolumn{2}{|c|}{ World-first } & \multicolumn{2}{|c|}{ Canada-first } & \multicolumn{2}{|c|}{ Other } \\
\hline & $\begin{array}{c}\text { Company } \\
\text { Weight }\end{array}$ & $\begin{array}{c}\text { Employment } \\
\text { Weight }\end{array}$ & $\begin{array}{c}\text { Company } \\
\text { Weight }\end{array}$ & $\begin{array}{c}\text { Employment } \\
\text { Weight }\end{array}$ & $\begin{array}{c}\text { Company } \\
\text { Weight }\end{array}$ & $\begin{array}{c}\text { Employment } \\
\text { Weight }\end{array}$ \\
\hline $\begin{array}{l}\text { Introduced innovations } \\
\text { Canadian-owned }\end{array}$ & 28 & 4.6 & 24 & 4.3 & 19 & 29 \\
\hline Foreign-owned & 4.9 & 6.3 & 0.6 & 2.8 & 1.9 & 1.9 \\
\hline Innovation in progress & & & & & & \\
\hline Canadian-owned & 2.2 & 2.7 & 2.2 & 1.5 & 1.2 & 1.9 \\
\hline Foreign-owned & 0.3 & 5.0 & 1.9 & 2.2 & 1.5 & 1.7 \\
\hline
\end{tabular}




\section{The Number of Innovations Introduced}

To this point, we have concentrated our analysis on differences in the incidence of innovation using information concerning the single most profitable innovation introduced by the firm in the 1989-1991 period. In order to assess the quantitative importance of innovation activity, we can also examine how many major innovations were introduced by firms during the period 19891991. The results (Table 18) show that foreign-owned firms were more prolific in creating product innovations (4.9 per firm) not involving any change in manufacturing technology than were Canadian-owned firms ( 2.8 per firm).

This pattern indicates that foreign affiliates have an advantage in introducing new and improved products developed by their parents. However, in the other two innovation categories, there are few differences, at least in the company-weighted estimates and domestically owned firms do slightly better in the employment-weighted estimates. Thus, the large domestically owned firms outperform foreign affiliates in the other two categories. Differences between foreign-owned and domestically owned firms for the number of innovations in progress-presented in the lower section of Table 18-generally mirror the results for the number of innovations introduced.

\section{Use of Intellectual Property Rights}

Firms vary in their innovation strategy. Some emphasize research and development and appropriability. Others pursue an imitative strategy. Intellectual property is protected and valued to different degrees by firms with different innovation strategies.

Foreign- and domestically owned firms might be expected to differ considerably in terms of their use of these forms of property protection. Foreign-owned firms are larger and tend to be located within high-tech sectors. More importantly, one of the advantages possessed by multinationals is their superior technological skills and their ability to transfer these skills across national boundaries (Caves, 1982). They might, therefore, be expected to make greater use of intellectual property protection than domestically owned firms.

Since foreign-owned firms are larger than domestically owned firms, differences between the two will be partly the result of nationality and partly the result of size. In order to account for size differences, the population was divided into large and small firms and differences between domestically owned and foreign-owned firms within each size class were examined. For the purpose of this exercise, small firms are defined as those with less than 200 employees, large firms as those with more than 200 employees. Comparisons of domestically owned and foreignowned firms within a size class allow the effect of nationality to be examined, holding size-class constant. 
Table 19. Multiple Use of Intellectual Property Protection

\begin{tabular}{c|c|c|c|c}
\hline \multirow{2}{*}{$\begin{array}{c}\text { Number of Intellectual } \\
\text { Property Types }\end{array}$} & \multicolumn{4}{|c}{ \% of Firms Using } \\
\cline { 2 - 5 } & $\begin{array}{c}\text { Small } \\
\text { Domestically } \\
\text { Owned }\end{array}$ & $\begin{array}{c}\text { Small } \\
\text { Foreign-Owned }\end{array}$ & $\begin{array}{c}\text { Large } \\
\text { Domestically } \\
\text { Owned }\end{array}$ & $\begin{array}{c}\text { Large } \\
\text { Foreign-Owned }\end{array}$ \\
\hline Any & 22 & 36 & 57 & 65 \\
1 & 13 & 21 & 28 & 26 \\
2 & 6 & 7 & 18 & 20 \\
3 & 2 & 6 & 6 & 9 \\
$4+$ & 1 & 1 & 4 & 10 \\
\hline
\end{tabular}

Table 20. Usage of Intellectual Protection by Foreign and Canadian Firms

\begin{tabular}{l|c|c|c|c}
\hline \multirow{2}{*}{ Form of Protection } & \multicolumn{4}{|c}{ \% of Firms Using } \\
\cline { 2 - 5 } & \multicolumn{3}{c}{ Firm Type } \\
\cline { 2 - 5 } & $\begin{array}{c}\text { Small } \\
\text { Domestically } \\
\text { Owned }\end{array}$ & $\begin{array}{c}\text { Small } \\
\text { Foreign-Owned }\end{array}$ & $\begin{array}{c}\text { Large } \\
\text { Domestically } \\
\text { Owned }\end{array}$ & $\begin{array}{c}\text { Large } \\
\text { Foreign-Owned }\end{array}$ \\
\hline Copyrights & 4 & 9 & 11 & 15 \\
Patents & 6 & 12 & 22 & 39 \\
Industrial Designs & 5 & 7 & 14 & 21 \\
Trade Secrets & 8 & 9 & 19 & 20 \\
Trade Marks & 10 & 21 & 31 & 42 \\
\hline
\end{tabular}

Table 21. Effectiveness of Intellectual Property Protection (company-weighted)

\begin{tabular}{l|c|c|c|c|c|c}
\hline \multirow{2}{*}{\begin{tabular}{c} 
Form of Protection \\
\cline { 2 - 6 }
\end{tabular}} & $\begin{array}{c}\text { All } \\
\text { Foreign }\end{array}$ & $\begin{array}{c}\text { Foreign } \\
\text { Users }\end{array}$ & $\begin{array}{c}\text { Foreign } \\
\text { Non-Users }\end{array}$ & $\begin{array}{c}\text { All } \\
\text { Canadian }\end{array}$ & $\begin{array}{c}\text { Canadian } \\
\text { Users }^{2}\end{array}$ & $\begin{array}{c}\text { Canadian } \\
\text { Non-Users }\end{array}$ \\
\cline { 2 - 7 } & 1 & 2 & 3 & 4 & 5 & 6 \\
\hline $\begin{array}{l}\text { Statutory Protection } \\
\text { Copyrights }\end{array}$ & 2.0 & 2.8 & 1.4 & 1.6 & 2.8 & 1.3 \\
Patents & 2.7 & 3.4 & 1.7 & 1.8 & 3.0 & 1.4 \\
Industrial Designs & 2.1 & 2.9 & 1.5 & 1.6 & 2.5 & 1.2 \\
Trade Secrets & 2.7 & 3.2 & 2.5 & 2.0 & 3.2 & 1.5 \\
$\quad$ Trade Marks & 2.6 & 3.1 & 1.6 & 2.0 & 3.1 & 1.4 \\
Other Strategies & 3.1 & 3.2 & 3.1 & 2.6 & 3.0 & 2.2 \\
Complexity of Product Designs & 3.1 & 3.4 & 2.7 & 3.2 & 3.4 & 3.0 \\
Being First in the Market & 2.5 & 3.5 & 1.3 & 2.3 & 2.6 & 2.1 \\
Other
\end{tabular}

${ }^{1}$ Rating Scale Used: 1: Not at All Effective; 2: Somewhat Effective; 3: Effective; 4: Very Effective; 5: Extremely Effective.

${ }^{2}$ Users are defined as those having the particular property right being scored. 
Not only do domestically owned firms use intellectual protection less frequently than foreign firms, they also value it less. When asked to score the efficacy of the different forms of intellectual property, foreign-owned firms rank every form of protection higher than do domestically owned firms (Table 21 , columns 1 versus 4).

This may be the result of inherent differences in the attitude taken by domestically owned and foreign-owned firms towards intellectual property protection. Whether there are inherent differences in attitudes can be tested by examining whether domestically owned and foreignowned firms that use statutory intellectual property rights view the effectiveness of these rights differently. When these two groups are compared (Table 21, columns 2 and 5), the differences are reduced and sometimes eliminated.

The differences between the scores given by foreign-owned and domestically owned populations to the efficacy of intellectual property protection thus come partially from the larger percentage of Canadian firms who do not make use of the form of protection and the lower scores that these firms give to the efficacy of protection in most areas. This non-using group tends not to be innovative, tends to utilise imitator strategies, and thus finds intellectual property law to be relatively unimportant. But in the case of patents, the fact that this difference persists even when users are examined suggests a difference in the extent to which Canadian firms manage their intellectual property assets.

This interpretation is born out by the fact that Canadian firms tend to have about the same attitude to the 'innate' forms of protection-whether complexity, being first in the market, or "other" are compared.

\section{Effects of Innovation}

That innovation activity, innovation intensity and the tendency to use intellectual property protection are higher in foreign-owned firms than in domestically owned firms may be either benefit or cost related. Foreign firms may be better able to reap particular types of benefits or domestically owned firms may experience more barriers to innovation.

The effects of innovation range from improved profits, quality, supplier and customer interactions, to increased market share, to reductions in costs. A comparison of the frequency of occurrence of these effects between foreign and domestic firms (Table 22) indicates that there are few major differences between the two groups. Exceptions occur. Canadian firms are more likely to note that innovation increased domestic market share and improved customer relations. Foreign-owned firms are more likely to associate innovation with increased foreign market share. But elsewhere about the same percentage of each group noted each benefit. 
Table 22. Effects of Innovation, by Ownership (\% of Firms, Company-weighted)

\begin{tabular}{l|r|r}
\hline \multirow{2}{*}{ Effects of Innovation } & \multicolumn{2}{|c}{ Ownership } \\
\cline { 2 - 3 } & $\begin{array}{c}\text { Canadian } \\
\text { Shareholder }\end{array}$ & $\begin{array}{c}\text { Foreign } \\
\text { Shareholder }\end{array}$ \\
\hline Improvements & 63.3 & 60.5 \\
Improved profit margin & 61.2 & 57.5 \\
Improved quality of products & 51.1 & 49.3 \\
Improved technological capabilities & 75.2 & 64.0 \\
Improved customer interactions & 26.5 & 18.8 \\
Improved suppliers interactions & 31.3 & 26.7 \\
Improved working conditions & 55.7 & 57.5 \\
Extended product range & & \\
Increased share & 67.8 & 56.7 \\
In domestic market & 37.0 & 48.3 \\
In foreign markets & & 27.8 \\
Cost reduction & 32.7 & 33.0 \\
Reduced lead times & 32.1 & 6.2 \\
Reduced labor requirements & 14.7 & 19.3 \\
Reduced design costs & 18.9 & 4.0 \\
Reduced material requirements & 6.4 & 16.6 \\
Reduced capital requirements & 16.8 & 15.8 \\
Regulations & 17.9 & \\
Environmental regulations & & \\
Health and safety regulations &
\end{tabular}

A breakdown by sector (not reported here) finds somewhat greater differences between the groups, but the differences are still mostly minor. Since foreign-owned firms are more likely to introduce process innovations than their Canadian counterparts, it follows that their innovations in the core sector tend to increase plant specialization and the scale of production, to reorganize work flows and to increase production flexibility more often than in Canadian firms. On the other hand, domestically owned firms are more likely to introduce product innovations fulfilling new functions and supplying new functional parts requiring improved interaction with customers and suppliers. Canadian-owned firms report these two effects significantly more often $(73.2 \%$ and $27.6 \%)$ than their foreign-owned counterparts (49.7\% and $14.0 \%)$.

\section{Do Foreign Affiliates Export More or Less Than Canadian-owned Firms?}

The important differences outlined above suggest that innovation differences between foreignowned and domestically owned firms are closely related to their different abilities to penetrate foreign markets. Innovation is costly. It might, therefore, be expected that firms that can spread their costs across both domestic and foreign sales have a greater ability to innovate. It is also the case that operations in foreign markets receive greater competitive stimuli than firms operating solely in domestic markets. While not all domestically controlled firms operate only in domestic markets, the group as a whole is less likely to be doing so than multinationals. 
Table 23. Export Incidence and Propensity, by Industrial Sector and Ownership (Innovating firms only)

\begin{tabular}{|c|c|c|c|c|c|c|c|c|c|}
\hline & & \multicolumn{2}{|c|}{ All } & \multicolumn{2}{|c|}{ Core } & \multicolumn{2}{|c|}{ Secondary } & \multicolumn{2}{|c|}{ Other } \\
\hline$\%$ of firms that exported* & Company-weighted & \multicolumn{2}{|c|}{0.41} & \multicolumn{2}{|c|}{0.51} & \multicolumn{2}{|c|}{0.43} & \multicolumn{2}{|c|}{0.32} \\
\hline Exports / sales & Employment-weighted & \multicolumn{2}{|c|}{0.29} & \multicolumn{2}{|c|}{0.39} & \multicolumn{2}{|c|}{0.27} & \multicolumn{2}{|c|}{0.22} \\
\hline Ownership & & Domestic & Foreign & Domestic & Foreign & Domestic & Foreign & Domestic & Foreign \\
\hline$\%$ of firms that exported* & Company-weighted & 0.38 & 0.57 & 0.51 & 0.54 & 0.32 & 0.74 & 0.33 & 0.25 \\
\hline Exports/sales by ownership & Employment-weighted & & & & & & & & \\
\hline All firms that declared sales & & 0.27 & 0.33 & 0.34 & 0.43 & 0.20 & 0.34 & 0.27 & 0.12 \\
\hline Only firms that exported & & 0.53 & 0.76 & 0.52 & 0.74 & 0.57 & 0.77 & 0.52 & 0.77 \\
\hline
\end{tabular}

Source : Table 29-Question 26-IPS only, December 22, 1998 and 5 January 1999

Note: * The ratio of the number of firms that export relative to the number of firms that declared sales (company-weighted). Ratios export/sales are employment weighted. 
The importance of foreign markets to the innovation process is investigated further by examining differences in the extent to which an innovation is sold in foreign markets and whether the share of sales derived from exports of an innovation is larger for foreign firms. These data, of course, are more likely to cover product innovations since sales data resulting from process innovations are not readily available.

About forty percent of all respondents who provided information ${ }^{13}$ on the value of domestic and foreign sales arising from their innovations are exporters. Core-sector firms export more often than those in the other two sectors. The proportion of foreign-owned firms that export is larger (57\%) than that of Canadian-owned firms (Table 23). More importantly, foreign affiliates also export a higher proportion of their sales from an innovation than do Canadian-owned firms. When this ratio is computed for all firms that declared reported sales from an innovation (but did not necessarily export), $33 \%$ of foreign affiliates sales but only $27 \%$ of domestically owned firms sales from an innovation are derived from exports. When this is calculated for just firms that do export, foreign-owned firms export a higher share of sales $(76 \%)$ than domestically owned firms $(53 \%)$. Thus, foreign-owned firms are more likely to export than domestically owned firms and the former export more intensively.

These differences vary to some extent across industry sectors. Canadian-owned firms operating in the core sector are almost as likely to export as their foreign counterparts. The reverse is true in the secondary sector, where foreign firms are more likely to export than domestically owned firms. However, the large majority of foreign-owned firms operating in the 'other' sector are not export oriented; only $25 \%$ declare export sales. And this is less than domestically owned firms. This suggests that most of the foreign-owned firms belonging to the 'other' sector innovate in Canada in order to adapt their products to the local market.

Despite differences across sectors in the probability of exporting an innovation, the export intensity of foreign-owned firms is always greater than for domestically owned firms. When an innovation results in export sales, it is more reliant on these sales in foreign-owned firms than in domestically owned firms.

\section{The Impact of Innovation on Employment and Skill Requirements}

One of the most frequently noted effects of innovation is on labour requirements. While both foreignowned and domestically owned firms are about as likely to report that innovation affected unit labour requirements, there is no reason to expect that this occurred in the same fashion.

Innovation affects employment in two ways. First, introducing new or improved production processes increases productivity. The technical change it introduces is likely to reduce unit labour requirements. This tends to reduce the demand for labour. On the other hand, a successful launching of a new or improved product may increase sales and lead to increased demand for employment.

\footnotetext{
${ }^{13}$ About half of larger innovating firms volunteered figures for domestic and export sales resulting from their most profitable innovation. Almost half of these firms exported.
} 
Foreign- and domestically owned firms may experience either a different effect of innovation on unit labour costs or on overall sales and thus experience a different effect of innovation on total employment.

Owing to the relative abundance of capital in Canada and in the United States, the home country of the largest proportion of foreign-owned firms operating in Canada, technical change is more likely to be labour rather than capital saving. However, relative factor cost differences between the two countries are rather small and it is unlikely that they would lead to systematic differences in the extent to which innovation was labour saving in Canadian as opposed to US-owned firms.

What is more important in determining differences in the demand for labour in the two groups is their different emphasis on product as opposed to process innovation. Foreign-owned firms introduced pure process innovations more often than did domestically owned firms. Process innovations are more likely to be labour saving than are product innovations. We would, therefore, expect that the effect of innovation in foreign firms is more likely to be labour saving than the product and combined product \& process innovations typically introduced by domestically owned firms.

This is the case. Innovations introduced by foreign affiliates appear to have a less beneficial effect on job creation than those introduced by locally owned firms. Almost twenty percent of foreign-owned firms report that their innovation decreased employment of production workers (Table 24). This compares with $11 \%$ of reporting Canadian-owned companies. Firms that created jobs are more numerous than firms that reduced them. But again, the positive effect is twice as important in domestically owned firms than in foreign ones $(39 \%$ of domestic and $22 \%$ of foreign).

This conclusion is based on the percentage of firms that indicate either a decrease or increase in employment. When employment-weighted data are used, the differences are not as clear. Now a greater percentage of employment is in domestically owned firms that decrease employment compared to foreign firms and there is little difference in terms of employment increases. Thus even though fewer Canadian than foreign-owned firms reduced employment, those that did were on average much larger than the foreign ones. The overall employment reduction impact could therefore be larger in the domestically owned sector. Ultimately, we would need data on the actual number of jobs eliminated to decide this issue and the survey did not try to collect this.

Technological change has been shifting the structure of employment by increasing the share of non-production workers in total employment (Baldwin and Rafiquzzaman, 1999). Results of the survey confirm that innovation is one of the causes of this change. The percentage of firms where innovation led to declines in non-production worker employment is marginal and similar in both ownership groups (3\% and 7\% for domestic and foreign firms, respectively) and virtually identical when weighted by employment. The creation of non-production worker jobs is also very similar in both the Canadian- and foreign-owned firms. It increased in about one quarter of firms, which represents one quarter of total employment in each group. Thus the employment impact of innovation on non-production or white-collar workers was broadly similar and probably positive in both Canadian and foreign-owned segments of the industry. 
Elsewhere, we have noted that innovation is accompanied by an increase in the skill requirements of firms (Baldwin, 1999). Despite the differences in the innovation profile of domestic- and foreign-controlled firms, innovation led to increased skill requirements in about the same proportion of domestically and foreign-owned firms (38\% and 40\%, respectively). Despite the fact that skill requirements are firm-specific, there was a general need to upgrade these requirements in both sectors.

\section{Ownership versus Trade Orientation}

Foreign-owned firms have been shown to generally be more likely to conduct R\&D and to introduce innovations than domestically owned firms that have neither foreign operations nor foreign sales. This does not mean that all domestically owned firms lack innovation capabilities. The difference between foreign-owned firms and what we have called internationally oriented firms is less than with domestically owned firms in general and in some cases not significant.

In the previous sections, we have defined an internationally oriented domestically owned firm as one that has either foreign production/R\&D facilities or foreign sales. This is a rather broad definition of international orientation because it includes domestically owned firms who make any foreign sales no matter how small. To test whether this definition affects the size of the difference between foreign and internationally oriented domestic firms, we change the definition to only include those firms with a substantial amount of foreign sales-where substantial is defined as $10 \%, 20 \%$ and $30 \%$, respectively. The R\&D and innovation intensities of the pure domestic (no foreign sales or production/R\&D facilities), those with less than $10 \%$ of sales as exports and those with foreign production facilities and more than 10\%, $20 \%$ and $30 \%$ of sales are reported in Table 25. For purposes of comparison, we also include the category we used for the internationally oriented firm in this paper - a firm with foreign production/R\&D facilities and/or exports sales.

It is apparent that as a domestically owned firm increases its export intensity, it moves closer to the profile of the foreign firms operating in Canada, though this effect generally diminishes beyond the 10\% export sales threshold. Thus, a firm that is more intensely involved in exports or one that we can refer to as more globalized resembles a foreign-owned firm operating in Canada quite closely in terms of its innovation profile.

These results indicate that it is globalization rather than nationality of ownership per se that affects the degree of innovativeness. 
Table 24. The effect of innovation on the number and skill requirements of workers in the firm by ownership (\% of firms, company and employment weighted)

\begin{tabular}{l|c|r|r|r|r|r|r}
\hline \multicolumn{1}{c|}{ Effects on } & \multirow{2}{*}{ Ownership } & \multicolumn{2}{c|}{ Decrease } & \multicolumn{2}{c|}{ Increase } & \multicolumn{2}{c}{ No change } \\
\cline { 3 - 7 } & & c-w & e-w & c-w & e-w & c-w & e-w \\
\hline Number of production workers & Domestic & 10.8 & 20.4 & 39.4 & 33.4 & 46.8 & 43.6 \\
& Foreign & 18.7 & 9.7 & 21.5 & 28.9 & 57.3 & 59.3 \\
Number of non-production workers & Domestic & 3.1 & 3.5 & 24.6 & 22.8 & 56.8 & 59.6 \\
& Foreign & 7.1 & 3.3 & 19.0 & 21.5 & 65.1 & 69.5 \\
Skill requirements of workers & Domestic & 0.5 & 0.1 & 38.0 & 28.8 & 61.5 & 71.0 \\
& Foreign & 2.1 & 3.9 & 39.7 & 34.7 & 58.5 & 61.4 \\
\hline
\end{tabular}

Table 25. Gradations of Innovativeness by Degree of Foreign Operations (\% of larger firms company weighted)

\begin{tabular}{|c|c|c|c|c|c|c|c|}
\hline & & $\begin{array}{c}\text { Inter- } \\
\text { national } \\
\text { Domestic }\end{array}$ & $\begin{array}{c}\text { Inter- } \\
\text { national } \\
\text { Domestic }\end{array}$ & $\begin{array}{c}\text { Inter- } \\
\text { national } \\
\text { Domestic }\end{array}$ & $\begin{array}{c}\text { Inter- } \\
\text { national } \\
\text { Domestic* }\end{array}$ & $\begin{array}{c}\text { Inter- } \\
\text { national } \\
\text { Domestic }\end{array}$ & $\begin{array}{c}\text { Pure } \\
\text { Domestic }\end{array}$ \\
\hline & Foreign & $\begin{array}{c}\text { Foreign } \\
\text { Production } \\
\text { or Foreign } \\
\text { Sales } \\
>\mathbf{3 0} \%\end{array}$ & $\begin{array}{c}\text { Foreign } \\
\text { Production } \\
\text { or Foreign } \\
\text { Sales } \\
>\mathbf{2 0 \%}\end{array}$ & $\begin{array}{c}\text { Foreign } \\
\text { Production } \\
\text { or Foreign } \\
\text { Sales } \\
>10 \%\end{array}$ & $\begin{array}{c}\text { Foreign } \\
\text { Production } \\
\text { Plus any } \\
\text { Foreign } \\
\text { Sales }\end{array}$ & $\begin{array}{c}\text { No Foreign } \\
\text { Production } \\
\text { and } \\
\text { Foreign } \\
\text { Sales } \\
<10 \%\end{array}$ & $\begin{array}{c}\text { No Foreign } \\
\text { Production } \\
\text { or Foreign } \\
\text { Sales }\end{array}$ \\
\hline$\%$ conducting $\mathrm{R} \& \mathrm{D}$ & 88.5 & 83.5 & 84.8 & 85.5 & 85.7 & 86.0 & 66.7 \\
\hline$\%$ conducting ongoing $\mathrm{R} \& \mathrm{D}$ & 53.4 & 53.0 & 49.2 & 48.3 & 44.7 & 39.1 & 38.8 \\
\hline$\%$ collaborating on $\mathrm{R} \& \mathrm{D}$ & 35.3 & 25.2 & 24.6 & 23.7 & 22.1 & 19.6 & 18.9 \\
\hline $\begin{array}{l}\% \text { with separate R\&D } \\
\text { department }\end{array}$ & 44.0 & 30.3 & 32.3 & 32.5 & 30.0 & 26.1 & 24.7 \\
\hline$\%$ with innovation & 52.4 & 47.0 & 47.5 & 48.6 & 47.0 & 45.7 & 28.7 \\
\hline$\%$ innovators with world-first & 24.8 & 23.0 & 22.0 & 20.5 & 14.4 & 13.0 & 4.8 \\
\hline
\end{tabular}

* this is the category used throughout this paper to represent an internationally oriented domestic firm. 


\section{Conclusion}

Foreign ownership in the manufacturing sector is highest in industries where multinationals can exploit their proprietary technological, marketing and R\&D assets.

Previous research has sought empirical evidence of the advantages of multinational investment with measures like labour productivity (Raynauld, 1972, Globerman, 1979) or measures of operational structure (Safarian, 1973). This paper examines the innovation capacity of multinationals operating in Canada and their success at innovation in a more direct fashion.

We find that even though they have a privileged access to their parent's R\&D and technology, foreign subsidiaries perform $R \& D$ in Canada more often than domestically owned firms. A breakdown by sector of activity shows, however, that the technological opportunities and imperatives existing in research intensive industries force the majority of firms (both domestic and foreign) in the core sector to perform R\&D. Foreign-owned firms in the core sector perform ongoing R\&D about as frequently as their Canadian counterparts. It is in the secondary and above all in the "other" sector where domestically owned firms as a group are less likely to perform R\&D than foreign affiliates. Foreign affiliates are also more likely to complement their own research and development activity by participating in joint ventures and $R \& D$ partnerships.

When determinants of R\&D activity such as the size of the firm, the sector of activity and various indicators of the competitive environment are taken into consideration, the probability that a firm performs R\&D is higher for firms under foreign ownership. Multinational firms not only exploit their proprietary advantages in Canada, but they also increasingly develop their own innovation initiatives and tap local sources of technology and scientific research.

One of the ways in which they do so is by collaborating with others on R\&D. Because of their involvement in $\mathrm{R} \& \mathrm{D}$ partnerships, there is no evidence to support the once popular argument that foreign firms do not develop R\&D links in Canada and thus create a truncated corporate structure in Canadian manufacturing.

Access to innovative ideas and technological expertise of their parent and sister companies confers a significant advantage on foreign affiliates over the Canadian-owned firms. This privileged source of innovative ideas and technology was, however, used only by about $40 \%$ of all foreign-owned firms.

There are two types of foreign affiliates-independent firms that do not rely heavily on affiliates for innovation and those that do so. The technologically more independent foreign affiliates rely more on their own R\&D and sales \& marketing in Canada. They are also closer to their customers. The more dependent foreign affiliates are closer to the traditional image of a branch plant implementing ideas received from parent companies.

To put their innovative ideas into practice, firms rely on a combination of internal and external sources for technological competence. Independent Canadian-owned companies do not have the luxury of using internal resources that are available within a multinational network and generate 
their own technological expertise through research and experimental development. Foreignowned firms make greater use of production engineering for this purpose; the difference is particularly important in the R\&D-intensive core sector. Another particularity of foreign-owned firms is that they rely more on technology from unrelated firms. The difference is again most notable in the core sector. Even though collaboration with universities and government laboratories is reported relatively less frequently as a source of technological expertise in the innovation process, foreign-owned firms use it more often than domestically owned firms, especially in the core sector.

Foreign-owned firms innovate in all sectors more frequently than their Canadian counterparts. This is true for most size categories. They especially surpass domestically owned firms in industries that are the recipients of innovations developed elsewhere. These are the industries that are most likely to be the recipients of new products or technologies developed in upstream industries. Here foreign-owned firms do research more frequently than domestically owned firms. Either they are better equipped to absorb innovations developed elsewhere or they are more capable of recognizing the advantages of $R \& D$ even in those industries where technological opportunity is in general less abundant. The most significant laggards are the largest Canadianowned firms belonging to the "other" sector. The situation is reversed in the medium size category of the core sector. In these R\&D-intensive industries that feed technology to the rest of economy, Canadian-owned medium size firms surpass their foreign-owned counterparts by a significant margin.

As far as the novelty of innovation is concerned, in keeping with their more frequent involvement in R\&D, foreign-owned firms surpass Canadian firms in introducing the more original world-first and Canada-first innovations. They therefore have more use for instruments of intellectual property than Canadian-owned companies. The foreign affiliates also have the advantage of arranging for the more efficient continuous transfer of technology as opposed to occasional discontinuous transfers.

As far as differences with respect to the effects of innovations are concerned, innovations introduced by foreign affiliates helped them to export and increase their share of foreign markets more often than domestically owned firms. Innovations introduced by domestically owned firms led more often to increased share of the local market. Foreign-owned innovating firms are also more export oriented than domestically owned firms and they export innovations more intensively than domestically owned firms.

All of these comparisons to domestically owned firms as a whole provide evidence that multinational firms do not operate subsidiaries in Canada that are truncated relative to Canadian firms in general. But these comparisons do not deal explicitly with the issue of whether foreign subsidiaries are truncated relative to a standard that is required of competitive global corporations. For this purpose, we have also compared foreign subsidiaries to Canadian corporations that have an international orientation. These additional comparisons to Canadian multinationals show that the two groups of multinationals are quite similar, both with regards to the likelihood that they conduct R\&D and that they introduce innovations. It is the international orientation of both foreign and domestically controlled firms that is related to their degree of innovativeness. 


\section{Appendix A}

Table 1A. Composition of the sample by nationality of ownership, by size - Standard Errors

(\% of larger firms, company weighted)

\begin{tabular}{|c|c|c|c|c|c|c|}
\hline \multirow{2}{*}{$\begin{array}{l}\text { Employment } \\
\text { Size Class }\end{array}$} & \multicolumn{6}{|c|}{ Manufacturing Firms Only - Majority Ownership } \\
\hline & $\begin{array}{c}\text { Canadian } \\
\text { Shareholder }\end{array}$ & $\begin{array}{c}\text { Foreign } \\
\text { Shareholder }\end{array}$ & USA & Europe & Pacific Rim & Other \\
\hline All & 1.17 & 1.17 & 0.93 & 0.67 & 0.34 & 0.23 \\
\hline $0-20$ & 1.68 & 1.68 & 1.15 & 1.25 & 0.00 & 0.00 \\
\hline $21-100$ & 1.47 & 1.47 & 1.24 & 0.69 & 0.47 & 0.22 \\
\hline $101-500$ & 2.87 & 2.87 & 2.28 & 1.73 & 0.89 & 0.79 \\
\hline $501-2000$ & 4.66 & 4.66 & 3.67 & 3.29 & 1.01 & 0.24 \\
\hline$>2000$ & 7.35 & 7.35 & 5.63 & 8.29 & 1.46 & 1.16 \\
\hline
\end{tabular}

Table 2A. Distribution of firms by ownership and sector - Standard Errors (\% of larger firms, company weighted)

\begin{tabular}{c|r|r}
\hline \multirow{2}{*}{$\begin{array}{c}\text { Employment } \\
\text { Size Class }\end{array}$} & \multicolumn{2}{|c}{ Majority Ownership } \\
\cline { 2 - 3 } & $\begin{array}{c}\text { Canadian } \\
\text { Shareholder }\end{array}$ & $\begin{array}{c}\text { Foreign } \\
\text { Shareholder }\end{array}$ \\
\hline All & 1.17 & 1.17 \\
Core & 3.16 & 3.16 \\
Secondary & 2.45 & 2.45 \\
Other & 1.19 & 1.19 \\
\hline
\end{tabular}


Table 3A. Incidence and organization of R\&D — Standard Errors

(\% of larger firms)

\begin{tabular}{|c|c|c|c|c|c|c|c|}
\hline Ownership & Weight & $\begin{array}{c}\% \\
\text { conduct } \\
\text { R\&D }\end{array}$ & $\begin{array}{c}\% \\
\text { doing } \\
\text { Ongoing } \\
\text { R\&D }\end{array}$ & $\begin{array}{c}\% \\
\text { with } \\
\text { Separate } \\
\text { R\&D } \\
\text { department } \\
\end{array}$ & \begin{tabular}{|c|}
$\%$ \\
performing \\
R\&D in \\
other \\
departments \\
\end{tabular} & $\begin{array}{c}\% \\
\text { contracting } \\
\text { out R\&D }\end{array}$ & $\begin{array}{c}\% \\
\text { collaborating } \\
\text { on R\&D }\end{array}$ \\
\hline Foreign & company & 1.7 & 4.0 & 4.0 & 4.0 & 2.8 & 3.7 \\
\hline All Domestic & company & 2.5 & 2.1 & 1.9 & 2.0 & 1.8 & 1.7 \\
\hline International Domestic & company & 2.0 & 2.7 & 2.4 & 2.6 & 2.2 & 2.1 \\
\hline with foreign operations $\& /$ or sales $>10 \%$ & company & 2.7 & 3.5 & 3.2 & 3.4 & 2.8 & 2.8 \\
\hline with foreign sales only: $<=10 \%$ & company & 3.1 & 4.3 & 3.9 & 4.2 & 3.7 & 3.5 \\
\hline Pure Domestic & company & 2.8 & 3.5 & 3.0 & 3.2 & 2.9 & 2.8 \\
\hline Foreign & employment & 3.5 & 4.1 & 4.9 & 6.2 & 6.2 & 5.9 \\
\hline All Domestic & employment & 2.3 & 4.1 & 4.1 & 4.1 & 4.4 & 4.1 \\
\hline International Domestic & employment & 1.2 & 4.7 & 4.7 & 4.7 & 4.8 & 4.8 \\
\hline with foreign operations \&/or sales > $10 \%$ & employment & 1.3 & 5.7 & 5.8 & 5.8 & 6.2 & 5.9 \\
\hline with foreign sales only: $<=10 \%$ & employment & 2.4 & 7.7 & 8.4 & 8.3 & 7.6 & 7.9 \\
\hline Pure Domestic & employment & 6.8 & 8.5 & 8.2 & 7.9 & 10.3 & 5.6 \\
\hline
\end{tabular}


Table 4A. Organization of R\&D by sector and origin of ownership - Standard Errors

(\% of large firms, company weighted)

\begin{tabular}{|c|c|c|c|c|c|}
\hline Sector/Ownership Type & $\begin{array}{c}\text { \% doing } \\
\text { Ongoing } \\
\text { R\&D }\end{array}$ & $\begin{array}{c}\text { \% with } \\
\text { Separate } \\
\text { R\&D } \\
\text { department } \\
\end{array}$ & $\begin{array}{l}\text { \% performing } \\
\text { R\&D in other } \\
\text { departments }\end{array}$ & $\begin{array}{c}\% \\
\text { contracting } \\
\text { out } R \& D\end{array}$ & $\begin{array}{c}\% \\
\text { collaborating } \\
\text { on R\&D }\end{array}$ \\
\hline \multicolumn{6}{|l|}{ Core } \\
\hline Foreign & 6.1 & 6.1 & 6.1 & 4.3 & 5.9 \\
\hline All Domestic & 4.6 & 4.6 & 4.6 & 4.1 & 4.1 \\
\hline International Domestic & 5.2 & 5.3 & 5.3 & 4.4 & 4.9 \\
\hline with foreign operations \&/or sales > $10 \%$ & 6.1 & 6.7 & 6.7 & 5.0 & 6.5 \\
\hline with foreign sales only: $<=10 \%$ & 9.2 & 9.1 & 9.1 & 8.4 & 6.9 \\
\hline Pure Domestic & 8.5 & 8.7 & 8.1 & 8.8 & 7.0 \\
\hline \multicolumn{6}{|l|}{ Secondary } \\
\hline Foreign & 7.4 & 7.0 & 7.2 & 5.2 & 6.2 \\
\hline All Domestic & 3.8 & 3.2 & 3.6 & 2.9 & 2.8 \\
\hline International Domestic & 4.8 & 4.0 & 4.4 & 3.7 & 3.5 \\
\hline with foreign operations $\& /$ or sales $>10 \%$ & 6.2 & 5.3 & 5.8 & 4.6 & 4.4 \\
\hline with foreign sales only: $<=10 \%$ & 7.7 & 6.8 & 7.4 & 6.6 & 6.0 \\
\hline Pure Domestic & 6.0 & 5.2 & 6.0 & 4.8 & 4.7 \\
\hline \multicolumn{6}{|l|}{ 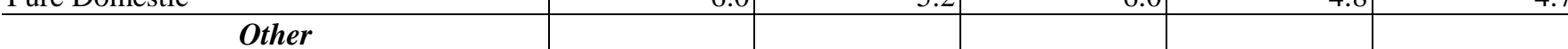 } \\
\hline Foreign & 7.4 & 7.3 & 7.2 & 5.1 & 6.7 \\
\hline All Domestic & 3.0 & 2.6 & 2.9 & 2.6 & 2.4 \\
\hline International Domestic & 3.9 & 3.4 & 3.9 & 3.5 & 3.1 \\
\hline with foreign operations \&/or sales > $10 \%$ & 5.2 & 4.7 & 5.3 & 4.6 & 3.8 \\
\hline with foreign sales only: $<=10 \%$ & 6.1 & 5.3 & 6.0 & 5.4 & 5.2 \\
\hline Pure Domestic & 4.8 & 4.1 & 4.3 & 3.9 & 3.9 \\
\hline
\end{tabular}


Table 8A. Internal sources of innovative ideas by origin of ownership by sectors - Standard Errors

(\% of innovating, larger firms, company weighted)

\begin{tabular}{|c|c|c|c|c|c|c|c|c|}
\hline \multirow{3}{*}{ Sector } & \multicolumn{8}{|c|}{ SECTORS } \\
\hline & \multicolumn{2}{|c|}{ All } & \multicolumn{2}{|c|}{ Core } & \multicolumn{2}{|c|}{ Secondary } & \multicolumn{2}{|c|}{ Other } \\
\hline & $\begin{array}{c}\text { Canadian } \\
\text { Shareholder }\end{array}$ & $\begin{array}{c}\text { Foreign } \\
\text { Shareholder }\end{array}$ & $\begin{array}{c}\text { Canadian } \\
\text { Shareholder }\end{array}$ & $\begin{array}{c}\text { Foreign } \\
\text { Shareholder }\end{array}$ & $\begin{array}{c}\text { Canadian } \\
\text { Shareholder }\end{array}$ & \begin{tabular}{c|} 
Foreign \\
Shareholder
\end{tabular} & $\begin{array}{c}\text { Canadian } \\
\text { Shareholder }\end{array}$ & $\begin{array}{c}\text { Foreign } \\
\text { Shareholder }\end{array}$ \\
\hline Management & 3.3 & 5.5 & 5.9 & 8.1 & 6.3 & 9.5 & 5.0 & 9.8 \\
\hline $\mathrm{R} \& \mathrm{D}$ & 3.2 & 5.6 & 5.8 & 7.6 & 6.2 & 9.8 & 4.1 & 9.8 \\
\hline Sales \& Marketing & 3.2 & 5.5 & 5.9 & 8.1 & 6.0 & 10.4 & 4.9 & 9.2 \\
\hline Production & 3.2 & 5.1 & 4.9 & 6.2 & 6.3 & 10.1 & 5.0 & 9.4 \\
\hline Other & 1.0 & 2.0 & 0.4 & 1.5 & 1.8 & 5.0 & 1.9 & 2.7 \\
\hline
\end{tabular}

Table 9A. External sources of innovative ideas by industry sectors and by origin of ownership — Standard Errors

(\% of larger innovating firms, company weighted)

\begin{tabular}{|c|c|c|c|c|c|c|c|c|}
\hline \multirow[b]{3}{*}{ SECTOR } & \multicolumn{8}{|c|}{ SECTORS } \\
\hline & \multicolumn{2}{|c|}{ ALL } & \multicolumn{2}{|c|}{ CORE } & \multicolumn{2}{|c|}{ SECONDARY } & \multicolumn{2}{|c|}{ OTHER } \\
\hline & $\begin{array}{l}\text { Canadian } \\
\text { Shareholder }\end{array}$ & $\begin{array}{c}\text { Foreign } \\
\text { Shareholder }\end{array}$ & $\begin{array}{l}\text { Canadian } \\
\text { Shareholder }\end{array}$ & $\begin{array}{c}\text { Foreign } \\
\text { Shareholder }\end{array}$ & $\begin{array}{l}\text { Canadian } \\
\text { Shareholder }\end{array}$ & $\begin{array}{c}\text { Foreign } \\
\text { Shareholder }\end{array}$ & $\begin{array}{l}\text { Canadian } \\
\text { Shareholder }\end{array}$ & $\begin{array}{c}\text { Foreign } \\
\text { Shareholder }\end{array}$ \\
\hline Suppliers & 3.0 & 5.0 & 4.9 & 8.5 & 5.5 & 6.7 & 4.8 & 9.8 \\
\hline Clients \& Customers & 3.3 & 5.9 & 8.1 & 10.0 & 5.0 & 10.0 & 5.0 & 7.9 \\
\hline Related Firms & 1.8 & 5.4 & 3.6 & 8.2 & 3.5 & 9.5 & 2.7 & 9.9 \\
\hline Competitors & 3.1 & 4.3 & 5.2 & 5.7 & 6.1 & 8.6 & 4.7 & 7.2 \\
\hline Government Regulations \& Standards & 2.0 & 2.7 & 4.2 & 2.8 & 4.9 & 4.2 & 1.6 & 8.9 \\
\hline Consultants & 2.2 & 2.9 & 4.1 & 5.4 & 5.4 & 4,0 & 2.4 & 4.5 \\
\hline Trade Fairs & 2.6 & 3.7 & 3.5 & 6.2 & 4.4 & 6.3 & 4.4 & 5.6 \\
\hline Professional Publications & 2.3 & 3.5 & 3.7 & 6.7 & 4.1 & 4.4 & 3.8 & 3.4 \\
\hline
\end{tabular}


Table 10A. Main sources of innovation ideas reported by foreign affiliates broken down Standard Errors by use of innovation idea and information from related firms

(\% of larger innovating firms, company weighted)

\begin{tabular}{l|r|r}
\hline \multirow{1}{*}{ Sector } & \multicolumn{2}{|c}{ Idea From Related Firms } \\
\cline { 2 - 3 } & Did Not Use & Used \\
\hline & & \\
Management & 7.1 & 7.3 \\
R\&D & 7.2 & 8.6 \\
Production & 6.2 & 8.5 \\
Sales \& Marketing & 7.4 & 7.7 \\
Suppliers & 5.8 & 8.6 \\
Clients \& Customers & 7.2 & 6.8 \\
& & \\
\hline
\end{tabular}


Table 11A. Internal and principal external sources of technology, by ownership and by industry sectors — Standard Errors (\% of larger innovating firms, company weighted)

\begin{tabular}{|c|c|c|c|c|c|c|c|c|}
\hline \multirow[b]{3}{*}{ Sector } & \multicolumn{8}{|c|}{ SECTORS } \\
\hline & \multicolumn{2}{|c|}{ All } & \multicolumn{2}{|c|}{ Core } & \multicolumn{2}{|c|}{ Secondary } & \multicolumn{2}{|c|}{ Other } \\
\hline & $\begin{array}{c}\text { Canadian } \\
\text { Shareholder }\end{array}$ & $\begin{array}{c}\text { Foreign } \\
\text { Shareholder }\end{array}$ & $\begin{array}{c}\text { Canadian } \\
\text { Shareholder }\end{array}$ & $\begin{array}{c}\text { Foreign } \\
\text { Shareholder }\end{array}$ & $\begin{array}{c}\text { Canadian } \\
\text { Shareholder }\end{array}$ & $\begin{array}{c}\text { Foreign } \\
\text { Shareholder }\end{array}$ & $\begin{array}{c}\text { Canadian } \\
\text { Shareholder }\end{array}$ & $\begin{array}{c}\text { Foreign } \\
\text { Shareholder }\end{array}$ \\
\hline Research & 3.4 & 5.4 & 6.4 & 8.6 & 6.5 & 8.0 & 4.1 & 7.4 \\
\hline Experimental Dev. & 3.7 & 5.9 & 6.0 & 8.6 & 7.2 & 11.5 & 5.7 & 9.4 \\
\hline Production Eng. & 3.7 & 5.4 & 6.4 & 8.6 & 6.7 & 5.8 & 5.7 & 9.5 \\
\hline Related Firm & 2.3 & 5.5 & 3.3 & 8.6 & 4.4 & 10.2 & 3.9 & 8.3 \\
\hline Unrelated Firm & 2.5 & 4.9 & 3.7 & 7.9 & 2.0 & 8.4 & 4.7 & 8.9 \\
\hline Consultants and Service Firms & 2.9 & 3.5 & 4.1 & 4.9 & 6.3 & 6.5 & 4.4 & 7.2 \\
\hline Publications & 1.9 & 3.6 & 4.8 & 6.8 & 0.5 & 5.4 & 2.9 & 1.4 \\
\hline Trade Fairs \& Conferences & 2.5 & 5.1 & 3.8 & 7.2 & 4.3 & 10.9 & 4.2 & 4.5 \\
\hline Government labs. & 1.2 & 2.1 & 2.8 & 2.2 & 1.5 & 5.4 & 1.8 & 0.0 \\
\hline University Labs. & 1.5 & 3.0 & 3.1 & 5.3 & 2.0 & 4.4 & 2.5 & 4.5 \\
\hline Customer Firm & 2.8 & 2.8 & 3.7 & 3.3 & 5.6 & 5.4 & 4.6 & 6.8 \\
\hline Supplier Firm & 3.5 & 5.7 & 5.2 & 7.6 & 6.2 & 12.0 & 5.8 & 8.7 \\
\hline
\end{tabular}

Table 12A. Type of Transferred Technology and Associated Restrictions — Standard Errors

(\% of large firms, company weighted)

\begin{tabular}{|c|c|c|}
\hline \multirow[b]{2}{*}{ Sector } & \multicolumn{2}{|c|}{ Ownership } \\
\hline & $\begin{array}{c}\text { Canadian } \\
\text { Shareholder }\end{array}$ & $\begin{array}{c}\text { Foreign } \\
\text { Shareholder }\end{array}$ \\
\hline Part of continuous Transfer & 5.9 & 10.3 \\
\hline One time transfer & 5.9 & 6.8 \\
\hline Cross-licensing & 1.2 & 4.1 \\
\hline Right to manufacture & 6.4 & 10.4 \\
\hline Right to sell & 6.4 & 8.0 \\
\hline Right to use in manufacturing & 5.9 & 9.0 \\
\hline Right to use patents & 4.8 & 8.6 \\
\hline Right to use industrial designs & 4.5 & 8.2 \\
\hline Right to use trade marks & 4.2 & 8.5 \\
\hline Right to use trade secrets & 4.9 & 10.1 \\
\hline Other rights & 4.1 & 6.7 \\
\hline
\end{tabular}


Table 13A. Impediments to Innovation by Sector and Ownership — Standard Errors

(\% of large firms, company weighted)

\begin{tabular}{|c|c|c|c|c|c|c|c|c|}
\hline \multirow[b]{3}{*}{ Sector } & \multicolumn{8}{|c|}{ SECTORS } \\
\hline & \multicolumn{2}{|c|}{ All } & \multicolumn{2}{|c|}{ Core } & \multicolumn{2}{|c|}{ Secondary } & \multicolumn{2}{|c|}{ Other } \\
\hline & \begin{tabular}{|c|} 
Canadian \\
Shareholder
\end{tabular} & \begin{tabular}{|c|} 
Foreign \\
Shareholder
\end{tabular} & \begin{tabular}{|l|} 
Canadian \\
Shareholder
\end{tabular} & $\begin{array}{c}\text { Foreign } \\
\text { Shareholder }\end{array}$ & $\begin{array}{c}\text { Canadian } \\
\text { Shareholder }\end{array}$ & \begin{tabular}{|c|} 
Foreign \\
Shareholder
\end{tabular} & \begin{tabular}{|c|} 
Canadian \\
Shareholder
\end{tabular} & \begin{tabular}{|c|} 
Foreign \\
Shareholder
\end{tabular} \\
\hline Lack of Skilled Personnel & 3.5 & 6.2 & 6.4 & 8.9 & 6.4 & 11.5 & 5.1 & 11.2 \\
\hline Lack of Info On Technology & 3.3 & 6.0 & 6.1 & 9.1 & 6.5 & 11.0 & 4.9 & 8.3 \\
\hline Lack of Info. On Markets & 3.1 & 6.0 & 6.3 & 8.9 & 5.9 & 11.6 & 4.4 & 3.4 \\
\hline Lack of Ext. Tech. Services & 2.4 & 3.9 & 5.1 & 3.4 & 3.5 & 8.9 & 3.8 & 5.9 \\
\hline Barriers to Interfirm Coop. & 2.6 & 5.2 & 5.0 & 5.1 & 4.1 & 11.5 & 4.1 & 2.3 \\
\hline Barriers To University Coop. & 1.7 & 1.5 & 3.3 & 3.1 & 2.7 & 1.7 & 2.6 & 0.0 \\
\hline Government Standards \& Regulations & 2.8 & 5.3 & 5.7 & 6.2 & 5.2 & 9.5 & 4.1 & 11.1 \\
\hline Other & 2.8 & 4.1 & 5.5 & 6.6 & 5.4 & 7.4 & 4.1 & 4.3 \\
\hline
\end{tabular}

Table 14A. Firms that Introduced, or Were in the Process of Introducing, an Innovation During the Period 1989-91, by Ownership Class and by Size - Standard Errors

(\% of large firms, company weighted)

\begin{tabular}{l|r|r|r|r}
\hline \multicolumn{1}{c|}{ Ownership } & \multicolumn{3}{c}{ Employment Size Class } \\
\cline { 2 - 5 } & \multicolumn{1}{c}{$\mathbf{2 1 - 1 0 0}$} & $\mathbf{1 0 1 - 5 0 0}$ & \multicolumn{1}{c}{ 501 plus } & All \\
\hline Foreign & 7.5 & 5.4 & 5.5 & 3.8 \\
All Domestic & 2.5 & 4.0 & 6.0 & 2.0 \\
International Domestic & 3.5 & 4.8 & 6.5 & 2.6 \\
with foreign operations \&/or sales > 10\% & 4.6 & 6.1 & 7.8 & 3.4 \\
with foreign sales only: <=10\% & 5.4 & 8.1 & 11.5 & 4.3 \\
Pure Domestic & 3.6 & 7.0 & 13.4 & 3.1 \\
\hline
\end{tabular}


Table 15A. Distribution of innovations by ownership, size of firm and sector - Standard Errors (\% of firms, company weighted)

\begin{tabular}{|c|c|c|c|c|}
\hline \multirow{2}{*}{ Sector/Ownership Type } & \multicolumn{4}{|c|}{ Employment Size Class } \\
\hline & 21-100 & $101-500$ & $500+$ & All \\
\hline Core & 12.4 & 8.9 & 7.9 & 6.0 \\
\hline Foreign & 6.1 & 7.6 & 11.1 & 4.5 \\
\hline All Domestic & 7.0 & 8.9 & 11.5 & 5.1 \\
\hline International Domestic & 8.9 & 9.5 & 15.2 & 6.3 \\
\hline with foreign operations $\& /$ or sales $>10 \%$ & 11.7 & 18.2 & 16.9 & 8.9 \\
\hline $\begin{array}{l}\text { with foreign sales only: }<=10 \% \\
\text { Pure Domestic }\end{array}$ & 11.7 & - & - & 9.9 \\
\hline Secondary & 10.4 & 10.2 & 10.6 & 6.6 \\
\hline Foreign & 4.4 & 7.3 & 10.6 & 3.7 \\
\hline All Domestic & 6.1 & 7.8 & 10.9 & 4.6 \\
\hline International Domestic & 8.2 & 9.7 & 11.6 & 6.0 \\
\hline with foreign operations \&/or sales $>10 \%$ & 9.0 & 13.9 & - & 7.5 \\
\hline with foreign sales only: $<=10 \%$ & 6.4 & 17.5 & - & 6.0 \\
\hline $\begin{array}{l}\text { Pure Domestic } \\
\text { Other }\end{array}$ & 103 & 8.5 & 100 & \\
\hline Foreign & 3.4 & $\begin{array}{l}0.5 \\
5.3\end{array}$ & $\begin{array}{r}10.0 \\
8.3\end{array}$ & $\begin{array}{l}6.2 \\
2.7\end{array}$ \\
\hline All Domestic & 5.0 & 7.3 & 9.2 & 3.8 \\
\hline International Domestic & 6.6 & 8.8 & 11.6 & 5.0 \\
\hline with foreign operations $\& /$ or sales $>10 \%$ & 7.8 & 11.4 & 15.5 & 6.1 \\
\hline $\begin{array}{l}\text { with foreign sales only: }<=10 \% \\
\text { Pure Domestic }\end{array}$ & 4.6 & 7.2 & 15.7 & 3.8 \\
\hline
\end{tabular}




\begin{tabular}{|c|c|c|c|c|}
\hline \multicolumn{5}{|c|}{$\begin{array}{l}\text { Standard Errors } \\
\text { (\% of large innovating firms, company weighted) }\end{array}$} \\
\hline Size & Ownership & Product & Process & $\begin{array}{c}\text { Product \& } \\
\text { Process } \\
\end{array}$ \\
\hline$\overline{\text { All }}$ & $\begin{array}{l}\text { Canadian } \\
\text { Foreign }\end{array}$ & $\begin{array}{l}3.1 \\
5.6\end{array}$ & $\begin{array}{l}3.3 \\
5.5\end{array}$ & $\begin{array}{l}3.3 \\
5.5\end{array}$ \\
\hline $21-100$ & $\begin{array}{l}\text { Canadian } \\
\text { Foreign }\end{array}$ & $\begin{array}{r}4.4 \\
12.6\end{array}$ & $\begin{array}{r}4.6 \\
11.7\end{array}$ & $\begin{array}{r}4.6 \\
11.8\end{array}$ \\
\hline $101-500$ & $\begin{array}{l}\text { Canadian } \\
\text { Foreign }\end{array}$ & $\begin{array}{l}5.8 \\
9.4\end{array}$ & $\begin{array}{l}6.1 \\
9.3\end{array}$ & $\begin{array}{l}6.1 \\
9.5\end{array}$ \\
\hline $501-2000$ & $\begin{array}{l}\text { Canadian } \\
\text { Foreign }\end{array}$ & $\begin{array}{l}9.4 \\
8.7\end{array}$ & $\begin{array}{l}8.9 \\
9.3\end{array}$ & $\begin{array}{l}9.6 \\
8.9\end{array}$ \\
\hline $2000+$ & $\begin{array}{l}\text { Canadian } \\
\text { Foreign }\end{array}$ & $\begin{array}{l}9.8 \\
8.1 \\
\end{array}$ & $\begin{array}{r}7.6 \\
15.0\end{array}$ & $\begin{array}{l}10.1 \\
13.8 \\
\end{array}$ \\
\hline
\end{tabular}


Table 17A. Originality of Innovations by Ownership and by Sector — Standard Errors

(\% of larger innovating firms)

\begin{tabular}{|c|c|c|c|c|c|c|c|c|}
\hline \multirow[b]{3}{*}{ Sector } & \multicolumn{8}{|c|}{ SECTORS } \\
\hline & \multicolumn{2}{|c|}{ All } & \multicolumn{2}{|c|}{ Core } & \multicolumn{2}{|c|}{ Secondary } & \multicolumn{2}{|c|}{ Other } \\
\hline & $\begin{array}{c}\text { Canadian } \\
\text { Shareholder }\end{array}$ & \begin{tabular}{|c|} 
Foreign \\
Shareholder
\end{tabular} & \begin{tabular}{|c|} 
Canadian \\
Shareholder
\end{tabular} & \begin{tabular}{|c|} 
Foreign \\
Shareholder
\end{tabular} & $\begin{array}{c}\text { Canadian } \\
\text { Shareholder }\end{array}$ & $\begin{array}{c}\text { Foreign } \\
\text { Shareholder }\end{array}$ & $\begin{array}{c}\text { Canadian } \\
\text { Shareholder }\end{array}$ & $\begin{array}{c}\text { Foreign } \\
\text { Shareholder }\end{array}$ \\
\hline Company weig & & & & & & & & \\
\hline World-first & 2.1 & 4.5 & 5.0 & 7.8 & 3.2 & 7.4 & 3.0 & 5.2 \\
\hline Canada-first & 3.0 & 5.7 & 5.8 & 8.3 & 6.1 & 10.6 & 4.3 & 9.0 \\
\hline Neither & 3.3 & 5.4 & 6.0 & 8.1 & 6.3 & 9.4 & 4.7 & 9.7 \\
\hline $\begin{array}{l}\text { Employment } \\
\text { weighted }\end{array}$ & & & & & & & & \\
\hline World-first & 4.4 & 8.3 & 11.9 & 12.4 & 7.5 & 17.1 & 4.1 & 6.8 \\
\hline Canada-first & 5.8 & 6.3 & 11.5 & 11.2 & 11.8 & 6.3 & 7.5 & 10.0 \\
\hline Neither & 5.7 & 8.1 & 7.0 & 5.9 & 11.2 & 18.2 & 7.8 & 11.3 \\
\hline
\end{tabular}

Table 18A. Number of innovations introduced and in progress by type of innovation and by ownership — Standard Errors

(\% of large firms, company weighted)

\begin{tabular}{|c|c|c|c|c|c|c|}
\hline \multirow[t]{2}{*}{ Ownership } & \multicolumn{2}{|c|}{$\begin{array}{c}\text { Product - no change in } \\
\text { manuf.tech. }\end{array}$} & \multicolumn{2}{|c|}{$\begin{array}{c}\text { Product and change in } \\
\text { manuf.tech. }\end{array}$} & \multicolumn{2}{|c|}{ Process - no product change } \\
\hline & $\begin{array}{c}\text { Company } \\
\text { Weight } \\
\end{array}$ & $\begin{array}{c}\text { Employment } \\
\text { Weight }\end{array}$ & $\begin{array}{c}\text { Company } \\
\text { Weight }\end{array}$ & $\begin{array}{c}\text { Employment } \\
\text { Weight }\end{array}$ & $\begin{array}{c}\text { Company } \\
\text { Weight }\end{array}$ & $\begin{array}{c}\text { Employment } \\
\text { Weight }\end{array}$ \\
\hline $\begin{array}{l}\text { Introduced innovations } \\
\text { Canadian-owned }\end{array}$ & 0.5 & 0.7 & 0.4 & 2.0 & 0.2 & 0.5 \\
\hline $\begin{array}{c}\text { Foreign-owned } \\
\text { Innovations in progress }\end{array}$ & 2.0 & 2.0 & 0.5 & 0.8 & 0.2 & 0.3 \\
\hline Canadian-owned & 0.4 & 0.5 & 0.4 & 0.2 & 0.1 & 0.4 \\
\hline Foreign-owned & 0.9 & 1.6 & 0.2 & 0.6 & 0.2 & 0.2 \\
\hline
\end{tabular}


Table 19A. Multiple Use of Intellectual Property Protection — Standard Errors (\% of firms, company weighted)

\begin{tabular}{l|c|c|c|c}
\hline \multirow{2}{*}{$\begin{array}{c}\text { Number of intellectual } \\
\text { property types }\end{array}$} & \multicolumn{4}{|c}{ Firm Type } \\
\cline { 2 - 5 } & $\begin{array}{c}\text { Small } \\
\text { Domestically } \\
\text { Owned }\end{array}$ & $\begin{array}{c}\text { Small } \\
\text { Foreign } \\
\text { Owned }\end{array}$ & $\begin{array}{c}\text { Large } \\
\text { Domestically } \\
\text { Owned }\end{array}$ & $\begin{array}{c}\text { Large } \\
\text { Foreign } \\
\text { Owned }\end{array}$ \\
\hline Any & 1.3 & 5.6 & 5.0 & 4.7 \\
1 & 1.0 & 5.0 & 4.1 & 4.6 \\
2 & 0.7 & 2.3 & 5.8 & 3.8 \\
3 & 0.4 & 1.8 & 1.6 & 2.1 \\
$4+$ & 0.3 & 0.7 & 1.3 & 3.0 \\
\hline
\end{tabular}

Table 20A. Usage of Intellectual Protection by Foreign and Canadian Firms - Standard Errors (\% of firms, company weighted)

\begin{tabular}{l|c|c|c|c}
\hline \multirow{2}{*}{ Form of Protection } & \multicolumn{4}{c}{ Firm Type } \\
\cline { 2 - 5 } & $\begin{array}{c}\text { Small } \\
\text { Domestically } \\
\text { Owned }\end{array}$ & $\begin{array}{c}\text { Small } \\
\text { Foreign } \\
\text { Owned }\end{array}$ & $\begin{array}{c}\text { Large } \\
\text { Domestically } \\
\text { Owned }\end{array}$ & $\begin{array}{c}\text { Large } \\
\text { Foreign } \\
\text { Owned }\end{array}$ \\
\hline Copyrights & 0.6 & 2.9 & 2.7 & 3.4 \\
Patents & 0.7 & 2.5 & 3.4 & 4.7 \\
Industrial Designs & 0.7 & 2.4 & 5.7 & 4.0 \\
Trade Secrets & 0.8 & 2.3 & 5.7 & 3.8 \\
Trade Marks & 0.8 & 4.7 & 4.2 & 4.8 \\
\hline
\end{tabular}

Table 21A. Effectiveness of intellectual property protection — Standard Errors (company-weighted)

\begin{tabular}{l|c|c|c|c|c|c}
\hline \multicolumn{1}{c|}{$\begin{array}{c}\text { Intellectual property rights } \\
\text { associated with }\end{array}$} & \multicolumn{7}{c}{ Average Score } \\
\cline { 2 - 6 } & $\begin{array}{c}\text { All } \\
\text { Foreign }\end{array}$ & $\begin{array}{c}\text { Foreign } \\
\text { Users }\end{array}$ & $\begin{array}{c}\text { Foreign } \\
\text { Non-Users }\end{array}$ & $\begin{array}{c}\text { All } \\
\text { Canadian }\end{array}$ & $\begin{array}{c}\text { Canadian } \\
\text { Users }\end{array}$ & $\begin{array}{c}\text { Canadian } \\
\text { Non-Users }\end{array}$ \\
\hline Statutory Protection & 0.2 & 0.2 & 0.2 & 0.1 & 0.2 & 0.1 \\
Copyrights & 0.2 & 0.2 & 0.3 & 0.1 & 0.1 & 0.1 \\
Patents & 0.2 & 0.3 & 0.2 & 0.1 & 0.2 & 0.1 \\
Industrial designs & 0.3 & 0.2 & 0.7 & 0.1 & 0.1 & 0.1 \\
Trade secrets & 0.2 & 0.2 & 0.2 & 0.1 & 0.1 & 0.1 \\
Trade-marks & & & & & & \\
Other strategies & & & & & & \\
Complexity of product design & 0.2 & 0.2 & 0.5 & 0.1 & 0.1 & 0.1 \\
Being first in market & 0.2 & 0.2 & 0.5 & 0.1 & 0.1 & 0.1 \\
Other & 0.6 & 0.5 & 0.3 & 0.2 & 0.3 & 0.3 \\
\hline
\end{tabular}


Table 22A. Effects of innovation, by ownership — Standard Errors (\% of firms, company weighted)

\begin{tabular}{l|r|r}
\hline \multicolumn{1}{c}{ Type of Transfer } & \multicolumn{2}{c}{ Ownership } \\
\cline { 2 - 3 } \multicolumn{1}{c|}{$\begin{array}{c}\text { Canadian } \\
\text { Shareholder }\end{array}$} & $\begin{array}{c}\text { Foreign } \\
\text { Shareholder }\end{array}$ \\
\hline Improved profit margin & 3.3 & 5.5 \\
Improved quality of products & 3.4 & 5.7 \\
Improved technological capabilities & 3.4 & 5.7 \\
Improved customer interactions & 2.9 & 5.8 \\
Improved suppliers interactions & 2.9 & 4.0 \\
Improved working conditions & 3.2 & 4.9 \\
Extended product range & 3.4 & 5.6 \\
\hline \multicolumn{1}{c|}{ Increased share } & 3.3 & \\
in domestic market & 3.3 & 5.7 \\
in foreign markets & & 5.7 \\
\hline \multicolumn{1}{c|}{ Cost Reduction } & 3.3 & 4.9 \\
Reduced lead times & 3.2 & 5.3 \\
Reduced labour requirements & 2.6 & 2.1 \\
Reduced design costs & 2.6 & 4.3 \\
Reduced material requirements & 1.6 & 1.6 \\
Reduced capital requirements & & 3.6 \\
Regulations & 2.4 & 3.7 \\
Environmental regulations & 2.6 & \\
Health and safety regulations &
\end{tabular}


Table 23A. Export Incidence and Propensity by industrial sector and ownership - Standard Errors

(\% of large innovating firms, company weighted)

\begin{tabular}{|c|c|c|c|c|c|c|c|c|}
\hline Type & \multicolumn{2}{|c|}{ All } & \multicolumn{2}{|c|}{ Core } & \multicolumn{2}{|c|}{ Secondary } & \multicolumn{2}{|c|}{ Other } \\
\hline exports / sales (e_wt) & \multirow{2}{*}{\multicolumn{2}{|c|}{$\begin{array}{l}\mathbf{0 . 0 5} \\
0.03\end{array}$}} & \multirow{2}{*}{\multicolumn{2}{|c|}{$\begin{array}{l}\mathbf{0 . 0 7} \\
0.05\end{array}$}} & & 0.09 & & 0.06 \\
\hline exports / sales (c_wt) & & & & & & 0.06 & & 0.05 \\
\hline$\%$ of firms that exported $(\mathrm{e}-\mathrm{wt})$ & \multicolumn{2}{|c|}{0.07} & \multicolumn{2}{|c|}{0.09} & & 0.12 & & 0.10 \\
\hline$\%$ of firms that exported (c_wt) & \multicolumn{2}{|c|}{0.04} & \multicolumn{2}{|c|}{0.06} & & 0.08 & & 0.06 \\
\hline \multirow[b]{2}{*}{ exports / sales by } & \multicolumn{2}{|c|}{ All } & \multicolumn{2}{|c|}{ Core } & \multicolumn{2}{|c|}{ Secondary } & \multicolumn{2}{|c|}{ Other } \\
\hline & \begin{tabular}{|c|} 
Canadian \\
Shareholder \\
\end{tabular} & $\begin{array}{c}\text { Foreign } \\
\text { Shareholder }\end{array}$ & \begin{tabular}{|c|} 
Canadian \\
Shareholder
\end{tabular} & \begin{tabular}{c|} 
Foreign \\
Shareholder
\end{tabular} & \begin{tabular}{|c|} 
Canadian \\
Shareholder
\end{tabular} & \begin{tabular}{c|} 
Foreign \\
Shareholder
\end{tabular} & $\begin{array}{c}\text { Canadian } \\
\text { Shareholder }\end{array}$ & $\begin{array}{c}\text { Foreign } \\
\text { Shareholder }\end{array}$ \\
\hline$\overline{\text { e_wt }}$ & 0.06 & 0.08 & 0.10 & 0.10 & 0.11 & 0.18 & 0.07 & 0.10 \\
\hline c_wt & 0.03 & 0.07 & 0.06 & 0.10 & 0.05 & 0.10 & 0.05 & 0.08 \\
\hline$\%$ of firms that exported (e_wt) & 0.08 & 0.11 & 0.12 & 0.13 & 0.13 & 0.23 & 0.11 & 0.13 \\
\hline$\%$ of firms that exported (c_wt) & 0.04 & 0.08 & 0.08 & 0.11 & 0.08 & 0.12 & $\mathbf{0 . 0 7}$ & 0.13 \\
\hline $\begin{array}{l}\text { All firms that declared sales } \\
\text { (e wt) }\end{array}$ & 0.06 & 0.08 & 0.1 & 0.1 & 0.11 & 0.18 & 0.07 & 0.1 \\
\hline All firms that declared sales (c_wt) & 0.03 & 0.07 & 0.06 & 0.1 & 0.05 & 0.1 & 0.05 & 0.08 \\
\hline Only firms that exported (e_wt) & 0.08 & 0.04 & 0.13 & 0.05 & 0.18 & 0.08 & 0.12 & 0.03 \\
\hline & 0.05 & 0.05 & 0.08 & & & & 0.09 & \\
\hline
\end{tabular}


Table 24A. The effect of innovation on the number and skill requirements of workers in the firm by ownership —Standard Errors

(\% of firms, company and employment weighted)

\begin{tabular}{|c|c|c|c|c|c|c|c|}
\hline \multirow[t]{2}{*}{ Effects on } & \multirow[t]{2}{*}{ Ownership } & \multicolumn{2}{|c|}{ Decrease } & \multicolumn{2}{|c|}{ Increase } & \multicolumn{2}{|c|}{ No change } \\
\hline & & $c-W$ & e-w & c-W & e-w & $c-w$ & e-w \\
\hline \multirow[t]{2}{*}{ Number of production workers } & Domestic & 2.0 & 5.5 & 3.4 & 5.1 & 3.5 & $\overline{5.8}$ \\
\hline & Foreign & 4.6 & 2.8 & 4.0 & 8.0 & 5.5 & 8.0 \\
\hline \multirow[t]{2}{*}{ Number of non-production workers } & Domestic & 1.1 & 1.6 & 3.0 & 4.7 & 3.4 & 5.5 \\
\hline & Foreign & 3.1 & 1.4 & 3.9 & 5.3 & 5.2 & 6.2 \\
\hline \multirow[t]{2}{*}{ Skill requirements of workers } & Domestic & 0.5 & 0.1 & 3.3 & 4.6 & 3.3 & 4.6 \\
\hline & Foreign & 2.1 & 5.7 & 5.7 & 7.8 & 5.7 & 8.0 \\
\hline
\end{tabular}

Table 25A. Gradations of Innovativeness by Degree of Foreign Operations — Standard Errors

(\% of larger firms - company weighted)

\begin{tabular}{|c|c|c|c|c|c|c|}
\hline & \multirow[b]{2}{*}{ Foreign } & $\begin{array}{c}\text { International } \\
\text { Domestic }\end{array}$ & $\begin{array}{c}\text { International } \\
\text { Domestic }\end{array}$ & $\begin{array}{c}\text { International } \\
\text { Domestic }\end{array}$ & $\begin{array}{c}\text { International } \\
\text { Domestic }\end{array}$ & $\begin{array}{c}\text { Pure } \\
\text { Domestic }\end{array}$ \\
\hline & & $\begin{array}{c}\text { Foreign } \\
\text { Production } \\
\text { or Foreign } \\
\text { Sales } \\
>\mathbf{3 0 \%}\end{array}$ & $\begin{array}{c}\text { Foreign } \\
\text { Production } \\
\text { or Foreign } \\
\text { Sales } \\
>\mathbf{2 0 \%}\end{array}$ & $\begin{array}{c}\text { Foreign } \\
\text { Production } \\
\text { or Foreign } \\
\text { Sales } \\
>10 \%\end{array}$ & $\begin{array}{c}\text { No Foreign } \\
\text { Production } \\
\text { and } \\
\text { Foreign } \\
\text { Sales } \\
<10 \%\end{array}$ & $\begin{array}{l}\text { No Foreign } \\
\text { Production } \\
\text { or Foreign } \\
\quad \text { Sales }\end{array}$ \\
\hline$\%$ conducting $\mathrm{R} \& \mathrm{D}$ & 2.5 & 3.3 & 2.9 & 2.7 & 3.1 & 2.8 \\
\hline$\%$ conducting ongoing $\mathrm{R} \& \mathrm{D}$ & 4.0 & 4.4 & 3.9 & 3.5 & 4.3 & 3.5 \\
\hline$\%$ collaborating on R\&D & 3.7 & 3.5 & 3.1 & 2.8 & 3.5 & 2.8 \\
\hline$\%$ with separate R\&D dept. & 4.0 & 3.9 & 3.5 & 3.2 & 3.9 & 3.0 \\
\hline$\%$ with innovation & 3.8 & 4.2 & 3.8 & 3.4 & 4.3 & 3.1 \\
\hline$\%$ innovators with world-first & 4.5 & 5.0 & 4.4 & 4.0 & 3.9 & 2.4 \\
\hline
\end{tabular}


Figure 1A. Performed R\&D on a regular basis - Standard Errors

\begin{tabular}{l|r|r|r|r|r|r}
\hline & $\begin{array}{c}\text { All } \\
\text { Domestic }\end{array}$ & $\begin{array}{c}\text { Pure } \\
\text { Domestic }\end{array}$ & $\begin{array}{c}\text { International } \\
\text { Domestic }\end{array}$ & $\begin{array}{c}\text { International } \\
\text { Domestic } \\
\text { with Foreign } \\
\text { Sales > 10\% }\end{array}$ & $\begin{array}{c}\text { International } \\
\text { Domestic } \\
\text { with Foreign } \\
\text { Sales <= 10\% }\end{array}$ & \multicolumn{1}{|c}{ Foreign } \\
\hline $21-100$ & 2.88 & 4.56 & 3.72 & 5.09 & 5.78 & 8.27 \\
$101-500$ & 4.31 & 8.55 & 4.95 & 6.35 & 7.71 & 6.03 \\
$500+$ & 5.61 & 13.79 & 6.19 & 7.64 & 11.12 & 5.54 \\
\hline
\end{tabular}

Figure 2A. Performed R\&D occasionally — Standard Errors

\begin{tabular}{l|r|r|r|r|r|r}
\hline & $\begin{array}{c}\text { All } \\
\text { Domestic }\end{array}$ & $\begin{array}{c}\text { Pure } \\
\text { Domestic }\end{array}$ & $\begin{array}{c}\text { International } \\
\text { Domestic }\end{array}$ & $\begin{array}{c}\text { International } \\
\text { Domestic } \\
\text { with Foreign } \\
\text { Sales > 10\% }\end{array}$ & $\begin{array}{c}\text { International } \\
\text { Domestic } \\
\text { with Foreign } \\
\text { Sales <= 10\% }\end{array}$ & \multicolumn{1}{|c}{ Foreign } \\
\hline $21-100$ & 2.88 & 4.54 & 3.72 & 5.09 & 5.78 & 8.25 \\
$101-500$ & 4.29 & 8.39 & 4.94 & 6.35 & 7.71 & 6.03 \\
$500+$ & 5.66 & 13.79 & 6.24 & 7.64 & 11.12 & 6.11 \\
\hline
\end{tabular}

Figure 3A. R\&D Performers with R\&D Collaborative Agreements - Standard Errors (\% of large firms, company-weighted)

\begin{tabular}{l|r|r|r|r|r|r}
\hline & $\begin{array}{c}\text { All } \\
\text { Domestic }\end{array}$ & $\begin{array}{c}\text { Pure } \\
\text { Domestic }\end{array}$ & $\begin{array}{c}\text { International } \\
\text { Domestic }\end{array}$ & $\begin{array}{c}\text { International } \\
\text { Domestic } \\
\text { with Foreign } \\
\text { Sales > 10\% }\end{array}$ & $\begin{array}{c}\text { International } \\
\text { Domestic } \\
\text { with Foreign } \\
\text { Sales <= 10\% }\end{array}$ & Foreign \\
\hline $21-100$ & 2.32 & 3.91 & 2.86 & 3.61 & 4.82 & 6.51 \\
$101-500$ & 3.54 & 5.54 & 4.36 & 5.78 & 6.72 & 5.65 \\
$500+$ & 5.63 & 13.25 & 6.22 & 7.40 & 11.99 & 6.43 \\
\hline
\end{tabular}

Figure 3A. R\&D Performers with R\&D Collaborative Agreements - Standard Errors (\% of large firms, employment-weighted)

\begin{tabular}{l|r|r|r|r|r|r}
\hline & $\begin{array}{c}\text { All } \\
\text { Domestic }\end{array}$ & \multicolumn{1}{c|}{$\begin{array}{c}\text { Pure } \\
\text { Domestic }\end{array}$} & $\begin{array}{c}\text { International } \\
\text { Domestic }\end{array}$ & $\begin{array}{c}\text { International } \\
\text { Domestic } \\
\text { with Foreign } \\
\text { Sales > 10\% }\end{array}$ & $\begin{array}{c}\text { International } \\
\text { Domestic } \\
\text { with Foreign } \\
\text { Sales <= 10\% }\end{array}$ & \multicolumn{1}{|c}{ Foreign } \\
\hline $21-100$ & 2.38 & 3.84 & 3.03 & 3.92 & 4.76 & 6.30 \\
$101-500$ & 4.16 & 5.70 & 4.98 & 6.56 & 5.91 & 5.98 \\
$500+$ & 6.09 & 12.48 & 6.59 & 7.68 & 13.50 & 7.20 \\
\hline
\end{tabular}


Figure 4A. Collaboration Partners, by ownership - Standard Errors

(\% of large innovating firms, company weighted)

\begin{tabular}{l|r|r}
\hline \multirow{2}{*}{\multicolumn{1}{c|}{ Sector }} & \multicolumn{2}{|c}{ IP Innovators } \\
\cline { 2 - 3 } & \multicolumn{1}{|c}{ Domestic } & \multicolumn{1}{c}{ Foreign } \\
\hline Customers - Canada & 4.93 & 6.16 \\
Customers - Foreign & 4.38 & 6.68 \\
Affiliates - Canada & 4.79 & 3.21 \\
Affiliates - Foreign & 4.55 & 6.85 \\
Competitors - Canada & 2.84 & 0.48 \\
Competitors - Foreign & 1.84 & 3.54 \\
R\&D Institutions - Canada & 5.11 & 6.48 \\
R\&D Institutions - Foreign & 2.45 & 4.24 \\
Universities/Colleges - Canada & 5.22 & 6.77 \\
Universities/Colleges - Foreign & 1.88 & 4.21 \\
Suppliers - Canada & 5.42 & 5.47 \\
Suppliers - Foreign & 4.66 & 5.85 \\
\hline
\end{tabular}

Figure 5A. Internal R\&D Sources for Foreign and Domestic Multinationals - Standard Errors (\% of large innovating firms, company weighted)

\begin{tabular}{l|r|r|r|r|r|r}
\hline & $\begin{array}{c}\text { All } \\
\text { Domestic }\end{array}$ & $\begin{array}{c}\text { Pure } \\
\text { Domestic }\end{array}$ & $\begin{array}{c}\text { International } \\
\text { Domestic }\end{array}$ & $\begin{array}{c}\text { International } \\
\text { Domestic } \\
\text { with Foreign } \\
\text { Sales > 10\% }\end{array}$ & $\begin{array}{c}\text { International } \\
\text { Domestic } \\
\text { with Foreign } \\
\text { Sales }<=\end{array}$ & Foreign \\
$10 \%$ & \\
\hline All & 3.17 & 5.94 & 3.70 & 4.85 & 5.90 & 5.55 \\
Core & 5.81 & 13.59 & 6.43 & 7.51 & 11.04 & 7.58 \\
Secondary & 6.24 & 13.94 & 6.91 & 8.75 & 11.75 & 9.77 \\
Other & 4.11 & 6.08 & 5.30 & 7.64 & 7.53 & 9.83 \\
\hline
\end{tabular}

Figure 6A. External Sources of Ideas - Standard Errors (\% of large firms, company weighted)

\begin{tabular}{l|r|r|r|r|r|r}
\hline & $\begin{array}{c}\text { All } \\
\text { Domestic }\end{array}$ & $\begin{array}{c}\text { Pure } \\
\text { Domestic }\end{array}$ & $\begin{array}{c}\text { International } \\
\text { Domestic }\end{array}$ & $\begin{array}{c}\text { International } \\
\text { Domestic } \\
\text { with Foreign } \\
\text { Sales }>10 \%\end{array}$ & $\begin{array}{c}\text { International } \\
\text { Domestic } \\
\text { with Foreign } \\
\text { Sales }<=\end{array}$ & Foreign \\
& & & & & & $10 \%$ \\
\hline Suppliers & 2.98 & 5.97 & 3.43 & 4.60 & 5.62 & 5.02 \\
Clients / Customers & 3.26 & 6.18 & 3.74 & 4.84 & 6.23 & 5.31 \\
Related Firms & 1.82 & 2.27 & 2.31 & 3.59 & 2.40 & 5.36 \\
Competitors & 3.07 & 6.18 & 3.54 & 4.46 & 5.86 & 4.25 \\
Government Regulations and Standards & 1.95 & 4.04 & 2.21 & 2.88 & 3.88 & 2.73 \\
Consultants & 2.2 & 3.76 & 2.66 & 3.14 & 4.77 & 2.91 \\
Trade Fairs / Conferences & 2.58 & 5.45 & 2.92 & 4.24 & 3.92 & 3.71 \\
Professional Publications & 2.31 & 6.2 & 2.04 & 2.66 & 3.51 & 3.45 \\
\hline
\end{tabular}


Figure 7A. Innovation Rate for Multinationals - Standard Errors

(\% of large innovating firms, company weighted)

\begin{tabular}{l|r|r|r|r|r|r}
\hline & $\begin{array}{c}\text { All } \\
\text { Domestic }\end{array}$ & $\begin{array}{c}\text { Pure } \\
\text { Domestic }\end{array}$ & $\begin{array}{c}\text { International } \\
\text { Domestic }\end{array}$ & $\begin{array}{c}\text { International } \\
\text { Domestic } \\
\text { with Foreign } \\
\text { Sales > 10\% }\end{array}$ & $\begin{array}{c}\text { International } \\
\text { Domestic } \\
\text { with Foreign } \\
\text { Sales }<=\end{array}$ & Foreign \\
$10 \%$ & \\
\hline Core & 4.53 & 9.87 & 5.06 & 6.27 & 8.92 & 5.97 \\
Secondary & 3.65 & 6.01 & 4.63 & 6.03 & 7.46 & 6.62 \\
Other & 2.74 & 3.8 & 3.84 & 5.01 & 6.11 & 6.23 \\
\hline
\end{tabular}

Figure 8A. Originality of Innovations - Standard Errors

(\% of large innovating firms, company weighted)

\begin{tabular}{l|r|r|r|r|r|r}
\hline & $\begin{array}{c}\text { All } \\
\text { Domestic }\end{array}$ & $\begin{array}{c}\text { Pure } \\
\text { Domestic }\end{array}$ & $\begin{array}{c}\text { International } \\
\text { Domestic }\end{array}$ & $\begin{array}{c}\text { International } \\
\text { Domestic } \\
\text { with Foreign } \\
\text { Sales > 10\% }\end{array}$ & $\begin{array}{c}\text { International } \\
\text { Domestic } \\
\text { with Foreign } \\
\text { Sales <= } \\
10 \%\end{array}$ & \multicolumn{1}{c}{ Foreign } \\
\hline World-first & 2.14 & 2.35 & 2.77 & 3.96 & 3.94 & 4.48 \\
Canada-First & 3.02 & 6.13 & 3.46 & 4.66 & 5.24 & 5.68 \\
Neither & 3.26 & 6.27 & 3.80 & 4.87 & 6.00 & 5.41 \\
\hline
\end{tabular}




\section{References}

Aitken, H.G. 1961. American Capital and Canadian Resources. Cambridge Mass. Harvard University Press.

Baldwin, J.R. 1997. The Importance of Research and Development for Innovation in Small and Large Canadian Manufacturing Firms. Research Paper Series No. 107. Analytical Studies Branch. Ottawa: Statistics Canada.

Baldwin, J.R. 1999. Training, Innovation and Success. Research Paper No. 137. Analytical Studies Branch. Ottawa: Statistics Canada.

Baldwin, J.R. and R.E. Caves. 1991. "Foreign Multinational Enterprises and Merger Activity in Canada." In Corporate Globalization through Mergers and Acquisitions. Edited by L. Waverman. Calgary: University of Calgary Press.

Baldwin, J.R. and M. Da Pont. 1996. Innovation in Canadian Manufacturing Enterprises. Catalogue 88-513-XPB. Ottawa: Statistics Canada.

Baldwin, J.R. and B. Diverty. 1995. Advanced Technology Use in Manufacturing Establishments. Research Paper No.85. Analytical Studies Branch. Statistics Canada.

Baldwin, J.R. and G. Gellatly. 1999. "Developing High-Tech Classification Schemes: A Competency-Based Approach." In New Technology-Based Firms in the 1990s: Volume VI. Edited by R. Oakey, W. During, and S. Mukhtar. Oxford: Elsevier Science Ltd.

Baldwin, J.R. and G. Gellatly. 2000. "A Firm-Based Approach to Industry Classification; Identifying the Knowledge-Based Economy." In The Knowledge-Based Economy. Edited by L. Lefebvre, E. Lefebvre and P. Mohnen. Holland: Kluwer Academic Publishers. Forthcoming.

Baldwin, J.R., P. Hanel and D. Sabourin. 2000. The Determinants of Innovative Activity in Canadian Manufacturing Firms. Research Paper Series No. 122. Analytical Studies Branch. Ottawa: Statistics Canada.

Baldwin, J.R. and D. Sabourin. 1997. Technology Adoption in Canadian Manufacturing; A Comparison across Plant Sizes. Micro-Economics and Analysis Division. mimeo.

Baldwin, J.R. and M. Rafiquzzaman. 1994. Structural Change in the Canadian Manufacturing Sector: 1970 to 1990. Research Paper No. 61. Analytical Studies Branch. Statistics Canada.

Baldwin, J.R. and M. Rafiquzzaman. 1995. Restructuring in the Canadian Manufacturing Sector: 1970 to 1990. Industry and Regional Dimension of Job Turnover. Research Paper No. 78. Analytical Studies Branch. Statistics Canada. 
Baldwin, J.R. and M. Rafiquzzaman. 1999. "The Effect of Technology and Trade on Wage Differentials Between Non-Production and Production Workers in Canadian Manufacturing," In Innovation, Industry Evolution and Employment. Edited by D.B Audretsch and R. Thurik. Cambridge: Cambridge University Press.

Baldwin, J.R., E. Rama and D. Sabourin. 1999. Growth of Advanced Technology Use in Canadian Manufacturing During the 1990's. Research Paper No. 105. Analytical Studies Branch. Statistics Canada.

Bartlett, C.A. and S. Ghoshal. 1989. Managing Across Borders, Boston, MA, Harvard Business School Press.

Britton, J.N.H. 1980. "Industrial Dependence and Technological Underdevelopment: Canadian Consequences of Foreign Direct Investment", Regional Studies 14: 181-199.

Britton, J.N.H. and Gilmour, J.M. 1978. The Weakest Link, Background Study. Ottawa: Science Council of Canada.

Caves, R.E. 1971. "International Corporations”, The Industrial Economics of Foreign Investment, Economica 38: 1-27.

Caves, R.E. 1982. Multinational Enterprise and Economic Analysis. Cambridge: Cambridge University Press.

Cohen, W.M. and Levinthal. 1989. "Innovation and Learning: Two Faces of R\&D." The Economic Journal 99: 569-596.

De Melto, D.P., K.E. McMullen, and R.M. Wills. 1980. Preliminary Report: Innovation and Technical Change in Five Canadian Industries. Discussion Paper No. 176. Ottawa: Economic Council of Canada.

Eden, L. (ed). 1994. Multinationals in North America, Industry Canada Research Series, vol. 3. Calgary: University of Calgary Press, pages xii, 557.

Eastman, H.C and S. Stykolt. 1967. The Tariff and Competition in Canada. Toronto: Macmillan.

Dunning, J.H. 1958. American Investment in British Manufacturing Industry. London: George Allen and Unwin.

Dunning, J.H. 1992. "Multinational Enterprises and the Globalization of Innovatory Capacity". In Technology Management and International Business: Internationalisation of $R \& D$ and Technology. Edited by O.Granstrand, L.Hakanson, and Sjolander. Chichester : John Wiley and Sons.

Dunning, J.H. 1993. Multinational Enterprises and the Global Economy. New York: AddisonWesley. 
Globerman, S. 1979. "Foreign Direct Investment and 'Spillover'. Efficiency Benefits in Canadian Manufacturing Industries." Canadian Journal of Economics, 12:42-56.

Globerman, Steven, J.C. Ries and I. Vetinsky. 1994. "The Economic Performance of Foreign Affiliates in Canada." Canadian Journal of Economics 27:143-156.

Granstrand, O.H.L. 1993. "Internationalization of R\&D—A Survey of Some Recent Research." Research Policy 22: 413-430.

Ghoshal, S. and C.A. Bartlett. 1990. "The Multinational Corporation as an Interorganizational Network", Academy of Management Review, 15: 4, 603-625.

Holbrook J.A.D. and R.J. Squires. 1996. Firm-Level Analysis of Determinants of Canadian Industrial R\&D Performance. Vancouver, Canada: Simon Fraser University at Harbour Centre.

Kuemmerle W. 1999. "Foreign direct investment in industrial research in the pharmaceutical and electronics industries-results from a survey of multinational firms". Special Issue, Research Policy, 28: 107-117.

Kumar V. 1995. The Role of $R \& D$ Consortia in Technology Development. Ottawa: Industry Canada.

Levin R.C. and P.C. Reiss. 1988. "Cost-Reducing and Demand-Creating R\&D with Spillovers." Rand Journal of Economics, 99: 569-96.

Levin, R.C. and P.C. Reiss. 1984. "Tests of a Schumpeterian Model of R\&D and Market Structure." in Z. Griliches ed.: R\&D, Patents and Productivity. Chicago, Chicago University Press.

Mowery, David C. and Nathan Rosenberg. 1989. Technology and Pursuit of Economic Growth. Cambridge University Press.

Niosi, J. 1995. Flexible Innovation. Technological Alliances in Canadian Industry. Montreal and Kingston: McGill-Queen's University Press.

Niosi, J. 1999. "Introduction, The Internalization of Industrial R\&D: From Technology transfer to learning organization, Special Issue, Research Policy, 28: 107-117.

Raynauld, A. 1972. "The Ownership and Performance of Firms," in The Multinational Firm and the Nation State. Edited by G. Paquette. Toronto: Ryerson Press.

Robson, M., J. Townsend, and Pavitt K. 1988. "Sectoral Patterns of Production and Use of Innovations in the UK: 1945-1983." Research Policy 17:1-14.

Safarian, A.E. 1973. Foreign Ownership of Canadian Industry. Toronto: University of Toronto Press. 
Saunders, R.S. 1980. "The Determinants of Productivity in Canadian Manufacturing Industries," Journal of Industrial Economics 29: 167-84.

Serapio, Manuel G. 1999. "Globalization of Industrial R\&D: an examination of foreign direct investment in R\&D in the United States." Research Policy, 28: 107-117.

Teece, David J. 1977. "Technology Transfer by Multinational Firms - the Resource Cost of Transferring Technological Know-how.” The Economic Journal 87: 242-61.

Teece, David J. 1986. "Profiting from Technological Innovation: Implications for Integration, Collaboration, Licensing and Public Policy." Research Policy 15: 285-305. 


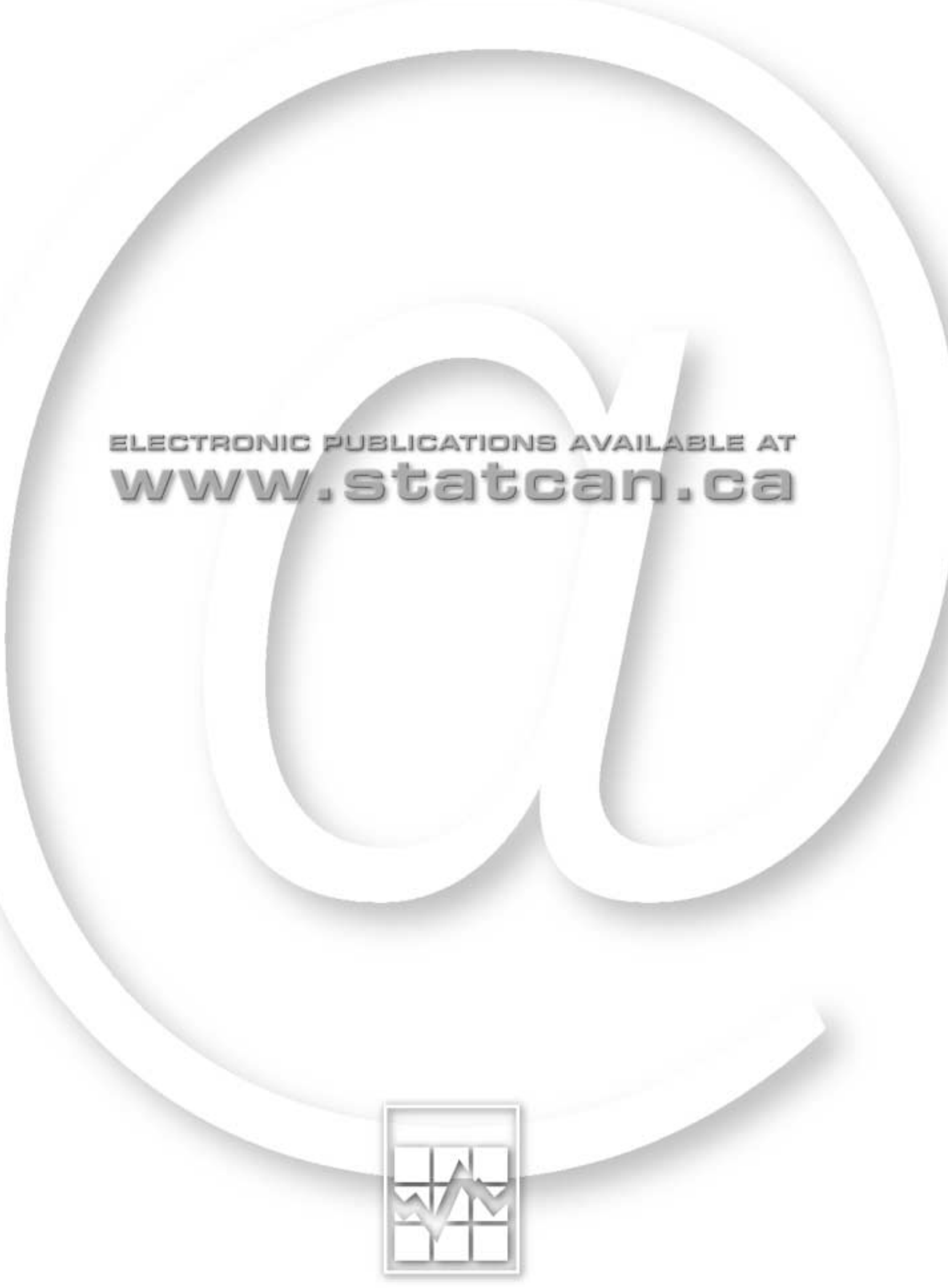




\section{ANALYTICAL STUDIES BRANCH RESEARCH PAPER SERIES}

No. 1 Behavioural Response in the Context of Socio-Economic Microanalytic Simulation, Lars Osberg (April 1986)

No. 2 Unemployment and Training, Garnett Picot (1987)

No. 3 Homemaker Pensions and Lifetime Redistribution, Michael Wolfson (August 1987)

No. 4 Modeling the Lifetime Employment Patterns of Canadians, Garnett Picot (Winter 1986)

No. 5 Job Loss and Labour Market Adjustment in the Canadian Economy, Garnett Picot and Ted Wannell (1987)

No. 6 A System of Health Statistics: Toward a New Conceptual Framework for Integrating Health Data, Michael C. Wolfson (March 1990)

No. 7 A Prototype Micro-Macro Link for the Canadian Household Sector, Hans J. Adler and Michael C. Wolfson (August 1987)

No. 8 Notes on Corporate Concentration and Canada's Income Tax, Michael C. Wolfson (October 1987)

No. 9 The Expanding Middle: Some Canadian Evidence on the Deskilling Debate, John Myles (Fall 1987)

No. 10 The Rise of the Conglomerate Economy, Jorge Niosi (1987)

No. 11 Energy Analysis of Canadian External Trade: 1971 and 1976, K.E. Hamilton (1988)

No. 12 Net and Gross Rates of Land Concentration, Ray D. Bollman and Philip Ehrensaft (1988)

No. 13 Cause-Deleted Life Tables for Canada (1972 to 1981): An Approach Towards Analyzing Epidemiological Transition, Dhruva Nagnur and Michael Nagrodski (November 1987)

No. 14 The Distribution of the Frequency of Occurrence of Nucleotide Subsequences, Based on Their Overlap Capability, Jane F. Gentleman and Ronald C. Mullin (1988)

No. 15 Immigration and the Ethnolinguistic Character of Canada and Quebec, Réjean Lachapelle (1988)

No. 16 Integration of Canadian Farm and Off-Farm Markets and the Off-Farm Work of Women, Men and Children, Ray D. Bollman and Pamela Smith (1988)

No. 17 Wages and Jobs in the 1980s: Changing Youth Wages and the Declining Middle, J. Myles, G. Picot and T. Wannell (July 1988)

No. 18 A Profile of Farmers with Computers, Ray D. Bollman (September 1988)

No. 19 Mortality Risk Distributions: A Life Table Analysis, Geoff Rowe (July 1988)

No. 20 Industrial Classification in the Canadian Census of Manufactures: Automated Verification Using Product Data, John S. Crysdale (January 1989) 
No. 21 Consumption, Income and Retirement, A.L. Robb and J.B. Burbridge (1989)

No. 22 Job Turnover in Canada's Manufacturing Sector, John R. Baldwin and Paul K. Gorecki (Summer 1989)

No. 23 Series on The Dynamics of the Competitive Process, John R. Baldwin and Paul K. Gorecki (1990)
A. Firm Entry and Exit Within the Canadian Manufacturing Sector.
B. Intra-Industry Mobility in the Canadian Manufacturing Sector.
C. Measuring Entry and Exit in Canadian Manufacturing: Methodology.
D. The Contribution of the Competitive Process to Productivity Growth: The Role of Firm and Plant Turnover.
E. Mergers and the Competitive Process.
F. n/a
G. Concentration Statistics as Predictors of the Intensity of Competition.
H. The Relationship Between Mobility and Concentration for the Canadian Manufacturing Sector.

No. 24 Mainframe SAS Enhancements in Support of Exploratory Data Analysis, Richard Johnson, Jane F. Gentleman and Monica Tomiak (1989)

No. 25 Dimensions of Labour Market Change in Canada: Intersectoral Shifts, Job and Worker Turnover, John R. Baldwin and Paul K. Gorecki (1989)

No. 26 The Persistent Gap: Exploring the Earnings Differential Between Recent Male and Female Postsecondary Graduates, Ted Wannell (1989)

No. 27 Estimating Agricultural Soil Erosion Losses From Census of Agriculture Crop Coverage Data, Douglas F. Trant (1989)

No. 28 Good Jobs/Bad Jobs and the Declining Middle: 1967-1986, Garnett Picot, John Myles, Ted Wannel (1990)

No. 29 Longitudinal Career Data for Selected Cohorts of Men and Women in the Public Service, 1978-1987, Garnett Picot and Ted Wannell (1990)

No. 30 Earnings and Death-Effects Over a Quarter Century, Michael Wolfson, Geoff Rowe, Jane F. Gentleman and Monica Tomiak (1990)

No. 31 Firm Response to Price Uncertainty: Tripartite Stabilization and the Western Canadian Cattle Industry, Theodore M. Horbulyk (1990)

No. 32 Smoothing Procedures for Simulated Longitudinal Microdata, Jane F. Gentleman, Dale Robertson and Monica Tomiak (1990)

No. 33 Patterns of Canadian Foreign Direct Investment Abroad, Paul K. Gorecki (1990)

No. 34 POHEM - A New Approach to the Estimation of Health Status Adjusted Life Expectancy, Michael C. Wolfson (1991)

No. 35 Canadian Jobs and Firm Size: Do Smaller Firms Pay Less?, René Morissette (1991)

No. 36 Distinguishing Characteristics of Foreign High Technology Acquisitions in Canada's Manufacturing Sector, John R. Baldwin and Paul K. Gorecki (1991)

No. 37 Industry Efficiency and Plant Turnover in the Canadian Manufacturing Sector, John R. Baldwin (1991) 
No. 38 When the Baby Boom Grows Old: Impacts on Canada's Public Sector, Brian B. Murphy and Michael C. Wolfson (1991)

No. 39 Trends in the Distribution of Employment by Employer Size: Recent Canadian Evidence, Ted Wannell (1991)

No. 40 Small Communities in Atlantic Canada: Their Industrial Structure and Labour Market Conditions in the Early 1980s, Garnett Picot and John Heath (1991)

No. 41 The Distribution of Federal/Provincial Taxes and Transfers in Rural Canada, Brian B. Murphy (1991)

No. 42 Foreign Multinational Enterprises and Merger Activity in Canada, John Baldwin and Richard Caves (1992)

No. 43 Repeat Users of the Unemployment Insurance Program, Miles Corak (1992)

No. 44 POHEM -- A Framework for Understanding and Modeling the Health of Human Populations, Michael C. Wolfson (1992)

No. 45 A Review of Models of Population Health Expectancy: A Micro-Simulation Perspective, Michael C. Wolfson and Kenneth G. Manton (1992)

No. 46 Career Earnings and Death: A Longitudinal Analysis of Older Canadian Men, Michael C. Wolfson, Geoff Rowe, Jane Gentleman and Monica Tomiak (1992)

No. 47 Longitudinal Patterns in the Duration of Unemployment Insurance Claims in Canada, Miles Corak (1992)

No. 48 The Dynamics of Firm Turnover and the Competitive Process, John Baldwin (1992)

No. 49 Development of Longitudinal Panel Data from Business Registers: Canadian Experience, John Baldwin, Richard Dupuy and William Penner (1992)

No. 50 The Calculation of Health-Adjusted Life Expectancy for a Canadian Province Using a Multi-Attribute Utility Function: A First Attempt, J.-M. Berthelot, R. Roberge and M.C. Wolfson (1992)

No. 51 Testing the Robustness of Entry Barriers, J.R. Baldwin and M. Rafiquzzaman (1993)

No. 52 Canada's Multinationals: Their Characteristics and Determinants, Paul K. Gorecki (1992)

No. 53 The Persistence of Unemployment: How Important were Regional Extended Unemployment Insurance Benefits?, Miles Corak, Stephen Jones (1993)

No. 54 Cyclical Variation in the Duration of Unemployment Spells, Miles Corak (1992)

No. 55 Permanent Layoffs and Displaced Workers: Cyclical Sensitivity, Concentration, and Experience Following the Layoff, Garnett Picot and Wendy Pyper (1993)

No. 56 The Duration of Unemployment During Boom and Bust, Miles Corak (1993)

No. 57 Getting a New Job in 1989-90 in Canada, René Morissette (1993)

No. 58 Linking Survey and Administrative Data to Study Determinants of Health, P. David, J.-M. Berthelot and C. Mustard (1993)

No. 59 Extending Historical Comparability in Industrial Classification, John S. Crysdale (1993) 
No. 60 What is Happening to Earnings Inequality in Canada?, R. Morissette, J. Myles and G. Picot (June 1994)

No. 61 Structural Change in the Canadian Manufacturing Sector, (1970-1990), J. Baldwin and M. Rafiquzzaman (July 1994)

No. 62 Unemployment Insurance, Work Disincentives, and the Canadian Labour Market: An Overview, Miles Corak (January 1994)

No. 63 Recent Youth Labour Market Experiences in Canada, Gordon Betcherman and René Morissette (July 1994)

No. 64 A Comparison of Job Creation and Job Destruction in Canada and the United States, John Baldwin, Timothy Dunne and John Haltiwanger (July 1994)

No. 65 What is Happening to Weekly Hours Worked in Canada?, René Morissette and Deborah Sunter (June 1994)

No. 66 Divergent Inequalities -- Theory, Empirical Results and Prescriptions, Michael C. Wolfson (May 1995)

No. 67 XEcon: An Experimental / Evolutionary Model of Economic Growth, Michael C. Wolfson (June 1995)

No. 68 The Gender Earnings Gap Among Recent Postsecondary Graduates, 1984-92, Ted Wannell and Nathalie Caron (November 1994)

No. 69 A Look at Employment-Equity Groups Among Recent Postsecondary Graduates: Visible Minorities, Aboriginal Peoples and the Activity Limited, Ted Wannell and Nathalie Caron (November 1994)

No. 70 Employment Generation by Small Producers in the Canadian Manufacturing Sector, John R. Baldwin and Garnett Picot (November 1994)

No. 71 Have Small Firms Created a Disproportionate Share of New Jobs in Canada? A Reassessment of the Facts, Garnett Picot, John Baldwin and Richard Dupuy (November 1994)

No. 72 Selection Versus Evolutionary Adaptation: Learning and Post-Entry Performance, J. Baldwin and M. Rafiquzzaman (May 1995)

No. 73 Business Strategies in Innovative and Non-Innovative Firms in Canada, J. Baldwin and J. Johnson (February 1995)

No. 74 Human Capital Development and Innovation: The Case of Training in Small and Medium Sized-Firms, J. Baldwin and J. Johnson (March 1995)

No. 75 Technology Use and Industrial Transformation: Emprirical Perspectives, John Baldwin, Brent Diverty and David Sabourin (August 1995)

No. 76 Innovation: The Key to Success in Small Firms, John R. Baldwin (February 1995)

No. 77 The Missing Link: Data on the Demand side of Labour Markets, Lars Osberg (April 1995)

No. 78 Restructuring in the Canadian Manufacturing Sector from 1970 to 1990: Industry and Regional Dimensions of Job Turnover, J. Baldwin and M. Rafiquzzaman (July 1995)

No. 79 Human Capital and the Use of Time, Frank Jones (June 1995)

No. 80 Why Has Inequality in Weekly Earnings Increased in Canada?, René Morissette (July 1995) 
No. 81 Socio-Economic Statistics and Public Policy: A New Role For Microsimulation Modeling, Michael C. Wolfson (July 1995)

No. 82 Social Transfers, Changing Family Structure, and Low Income Among Children, Garnett Picot and John Myles (September 1995)

No. 83 Alternative Measures of the Average Duration of Unemployment, Miles Corak and Andrew Heisz (October 1995)

No. 84 The Duration of Unemployment: A User Guide, Miles Corak and Andrew Heisz (December 1995)

No. 85 Advanced Technology Use in Manufacturing Establishments, John R. Baldwin and Brent Diverty (November 1995)

No. 86 Technology Use, Training and Plant-Specific Knowledge in Manufacturing Establishments, John R. Baldwin, Tara Gray and Joanne Johnson (December 1995)

No. 87 Productivity Growth, Plant Turnover and Restructuring in the Canadian Manufacturin Sector, John R. Baldwin (November 1995)

No. 88 Were Small Producers the Engines of Growth in the Canadian Manufacturing Sector in the 1980s?, John R. Baldwin (October 1996)

No. 89 The Intergenerational Income Mobility of Canadian Men, Miles Corak and Andrew Heisz (January 1996)

No. 90 The Evolution of Payroll Taxes in Canada: 1961 - 1993, Zhengxi Lin, Garnett Picot and Charles Beach (February 1996)

No. 91 Project on Matching Census 1986 Database and Manitoba Health Care Files: Private Households Component, Christian Houle, Jean-Marie Berthelot, Pierre David, Cam Mustard, Roos L. and M.C. Wolfson (March 1996)

No. 92 Technology-induced Wage Premia in Canadian Manufacturing Plants during the 1980s, John Baldwin, Tara Gray and Joanne Johnson (December 1996)

No. 93 Job Creation by Company Size Class: Concentration and Persistence of Job Gains and Losses in Canadian Companies, Garnett Picot and Richard Dupuy (April 1996)

No. 94 Longitudinal Aspects of Earnings Inequality in Canada, René Morissette and Charles Bérubé (July 1996)

No. 95 Changes in Job Tenure and Job Stability in Canada, Andrew Heisz (November 1996)

No. 96 Are Canadians More Likely to Lose Their Jobs in the 1990s?, Garnett Picot and Zhengxi Lin (August 6, 1997)

No. 97 Unemployment in the Stock and Flow, Michael Baker, Miles Corak and Andrew Heisz (September 1996)

No. 98 The Effect of Technology and Trade on Wage Differentials Between Nonproduction and Production Workers in Canadian Manufacturing, by John R. Baldwin and Mohammed Rafiquzzaman (May 1998)

No. 99 Use of POHEM to Estimate Direct Medical Costs of Current Practice and New Treatments Associated with Lung Cancer in Canada, C. Houle, B.P. Will, J.-M. Berthelot, Dr. W.K. Evans (May 1997)

No. 100 An Experimental Canadian Survey That Links Workplace Practices and Employee Outcomes: Why it is Needed and How it Works, Garnett Picot, Ted Wannell (May 1997) 
No. 101 Innovative Activity in Canadian Food Processing Establishments: The Importance of Engineering Practices, John Baldwin and David Sabourin (November 1999)

No. 102 Differences in Strategies and Performances of Different Types of Innovators, John R. Baldwin and Joanne Johnson (December 1997)

No. 103 Permanent Layoffs in Canada: Overview and Longitudinal Analysis, Garnett Picot, Zhengxi Lin and Wendy Pyper (September, 1997)

No. 104 Working More? Working Less? What do Canadian Workers Prefer?, Marie Drolet and René Morissette (May 20, 1997)

No. 105 Growth of Advanced Technology Use in Canadian Manufacturing During the 1990's, John Baldwin, Ed Rama and David Sabourin (December 14, 1999)

No. 106 Job Turnover and Labour Market Adjustment in Ontario from 1978 to 1993, Zhengxi Lin and Wendy Pyper (1997)

No. 107 The Importance of Research and Development for Innovation in Small and Large Canadian Manufacturing Firms, John R. Baldwin (September 24, 1997)

No. 108 International Competition and Industrial Performance: Allocative Efficiency, Productive Efficiency, and Turbulence, John R. Baldwin and Richard E. Caves (October 1997)

No. 109 The Dimensions of Wage Inequality among Aboriginal Peoples, Rachel Bernier (December 1997)

No. 110 Trickling Down or Fizzling Out? Economic Performance, Transfers, Inequality and Low Income, Myles Zyblock and Zhengxi Lin (December 10, 1997)

No. 111 Corporate Financial Leverage: A Canada - U.S. Comparison, 1961-1996, Myles Zyblock (December 1997)

No. 112 An explanation of the Increasing Age Premium, Constantine Kapsalis (July 1998)

No. 113 The Intergenerational Earnings and Income Mobility of Canadian Men: Evidence from Longitudinal Income Tax Data, Miles Corak and Andrew Heisz (October, 1998)

No. 114 Foreign-Born vs Native-Born Canadians: A Comparison of Their Inter-Provincial Labour Mobility, Zhengxi Lin (September 1998)

No. 115 Living Arrangements and Residential Overcrowding: the situation of older immigrants in Canada, 1991, K.G. Basavarajappa (September 1998)

No. 116 What is Happening to Earnings Inequality and Youth Wages in the 1990s?, Garnett Picot (July 1998)

No. 117 The Determinants of the Adoption Lag for Advanced Manufacturing Technologies, John R. Baldwin and Mohammed Rafiquzzaman (August 1998)

No. 118 Labour Productivity Differences Between Domestic and Foreign-Controlled Establishments in the Canadian Manufacturing Sector, John R. Baldwin and Naginder Dhaliwal (March 1, 2000)

No. 119 Technology Adoption: A Comparison Between Canada and the United States, John R. Baldwin and David Sabourin (August 1998) 
No. 120 Are There High-Tech Industries or Only High-Tech Firms? Evidence From New TechnologyBased firms, John R. Baldwin and Guy Gellatly (December 1998)

No. 121 A Portrait of Entrants and Exits, John R. Baldwin (June 1999)

No. 122 Determinants of Innovative Activity in Canadian Manufacturing Firms: The Role of Intellectual Property Right, John R. Baldwin, Petr Hanel and David Sabourin (March 7, 2000)

No. 123 In progress (John Baldwin)

No. 124 New Views on Inequality Trends in Canada and the United States, Michael C. Wolfson and Brian B. Murphy (August 1998 and October 1999 (paper))

No. 125 Employment Insurance in Canada: Recent Trends and Policy Changes, Zhengxi Lin (September 1998)

No. 126 Computers, Fax Machines and Wages in Canada: What Really Matters?, René Morissette and Marie Drolet (October 1998)

No. 127 Understanding the Innovation Process: Innovation in Dynamic Service Industries, Guy Gellatly and Valerie Peters (December 1999)

No. 128 Recent Canadian Evidence on Job Quality by Firm Size, Marie Drolet and René Morissette (November 1998)

No. 129 Distribution, Inequality and Concentration of Income Among Older Immigrants in Canada, 1990, K.G. Basavarajappa (April 1999)

No. 130 Earnings Dynamics and Inequality among Canadian Men, 1976-1992: Evidence from Longitudinal Income Tax Records, Michael Baker and Gary Solon (February 1999)

No. 131 The Returns to Education, and the Increasing Wage Gap Between Younger and Older Workers, C. Kapsalis, R. Morissette and G. Picot (March 1999)

No. 132 Why Do Children Move Into and Out of Low Income: Changing Labour Market Conditions or Marriage and Divorce?, G. Picot, M. Zyblock and W. Pyper (March 1999)

No. 133 Rising Self-Employment in the Midst of High Unemployment: An Empirical Analysis of Recent Developments in Canada, Zhengxi Lin, Janice Yates and Garnett Picot (March 1999)

No. 134 The Entry and Exit Dynamics of Self-Employment in Canada, Zhengxi Lin, Garnett Picot and Janice Yates (March 1999)

No. 135 Death and Divorce: The Long-term Consequences of Parental Loss on Adolescents, by Miles Corak (June 9, 1999)

No. 136 In progress (Frank Jones)

No. 137 Innovation, Training and Success, John Baldwin (October 1999)

No. 138 The Evolution of Pension Coverage of Young and Older Workers in Canada, René Morissette and Marie Drolet (December 1999)

No. 139 Import Competition and Market Power: Canadian Evidence, Aileen J. Thompson (April 2000)

No. 140 In Progress 
No. 141 In Progress

No. 142 In Progress

No. 143 Differences in Innovator and Non-Innovator Profiles: Small Establishments in Business Services, Guy Gellatly (December 1999)

No. 144 Social Transfers, Earnings and Low-Income Intensity Among Canadian Children, 1981-1996: Highlighting Recent Development in Low-Income Measurement, John Myles and Garnett Picot (March 2000)

No. 145 In Progress

No. 146 To What Extent Are Canadians Exposed to Low-Income?, René Morissette and Marie Drolet (April, 2000)

No. 147 The Maturation of Canada's Retirement Income System: Income Levels, Income Inequality and Low-Income among the Elderly, John Myles (March 6, 2000)

No. 148 The Performance of the 1990s Canadian Labour Market, Garnett Picot and Andrew Heisz (April, 2000)

No. 149 In Progress

No. 150 Patterns of Corporate Diversification in Canada: An Empirical Analysis, John R. Baldwin, Desmond Beckstead, Guy Gellatly and Alice Peters (June, 2000)

No. 151 Multinationals and the Canadian Innovation Process, John R. Baldwin and Petr Hanel (June, 2000) 